\title{
GRAU DE MOAGEM DO MILHO, INCLUSÃO DE SUBPRODUTOS AGROINDUSTRIAIS E ADITIVO MICROBIOLÓGICO EM RAÇÕES PARA VACAS LEITEIRAS
}

\author{
CAROLINA DE ALMEIDA CARMO
}

Tese apresentada à Escola Superior de Agricultura "Luiz de Queiroz", Universidade de São Paulo, para obtenção do título de Doutor em Agronomia, Área de Concentração: Ciência Animal e Pastagens.

PIRACICABA

Estado de São Paulo - Brasil

Junho de 2005 


\section{GRAU DE MOAGEM DO MILHO, INCLUSÃO DE SUBPRODUTOS AGROINDUSTRIAIS E ADITIVO MICROBIOLÓGICO EM RAÇÕES PARA VACAS LEITEIRAS}

\section{CAROLINA DE ALMEIDA CARMO}

Zootecnista

Orientador: Prof. Dr. FLÁVIO AUGUSTO PORTELA SANTOS

Tese apresentada à Escola Superior de Agricultura "Luiz de Queiroz", Universidade de São Paulo, para obtenção do título de Doutor em Agronomia, Área de Concentração: Ciência Animal e Pastagens.

PIRACICABA

Estado de São Paulo - Brasil

Junho - 2005 
Dados Internacionais de Catalogação na Publicação (CIP) DIVISÃO DE BIBLIOTECA E DOCUMENTAÇÃO - ESALQ/USP

\section{Carmo, Carolina de Almeida}

Grau de moagem do milho, inclusão de subprodutos agroindustriais e aditivo microbiológico em rações para vacas leiteiras / Carolina de Almeida Carmo. - Piracicaba, 2005.

$105 \mathrm{p}$

Tese (doutorado) - - Escola Superior de Agricultura Luiz de Queiroz, 2005. Bibliografia.

1. Aditivos alimentares para animal 2. Lactação animal 3. Milho 4. Moagem 5. Rações 6. Subprodutos para animal 7. Vacas leiteiras I. Título

CDD 636.214

\section{"Permitida a cópia total ou parcial deste documento, desde que citada a fonte - O autor"}


"Procure ser uma pessoa de valor, em vez de procurar ser uma pessoa de sucesso. O sucesso é conseqüência."

(Albert Einstein) 
Dedico

aos meus queridos

Mãe, Pai, Lu, Bibi,

Dri, Ayrtinho e Beto 


\section{AGRADECIMENTOS}

Especialmente, ao meu orientador e grande exemplo de vida profissional, Prof. Dr. Flávio Augusto Portela Santos.

À FAPESP, pelo financiamento do projeto de pesquisa e pela concessão da bolsa de estudos.

Aos Profs. Dr. Wilson Mattos e Dr. Luiz Gustavo Nussio e à Pesquisadora Dra. Carla Nussio, pelas valiosas contribuições e ensinamentos.

À Profa. Dra. Telma Berchielli, pela sempre imediata disposição em colaborar na minha formação.

À Novanis Animal Ltda., pela doação da casca de soja.

Ao Carlos César Alves, pela ajuda nas análises laboratoriais.

Aos colegas Rodrigo, Rafael, Alexandre, Narson, Térssio, Eduardo, Marcos, Paula, Junio, Hugo e Tadeu pela ajuda na condução da fase experimental. 


\section{SUMÁRIO}

Página

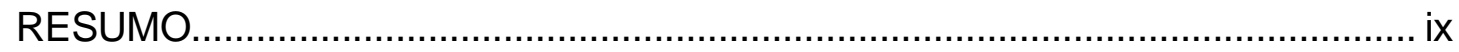

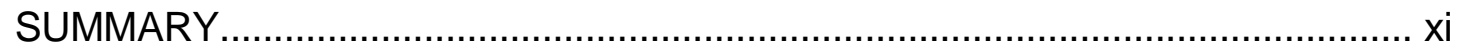

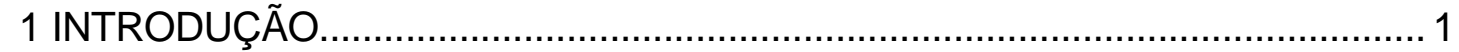

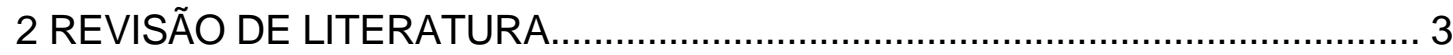

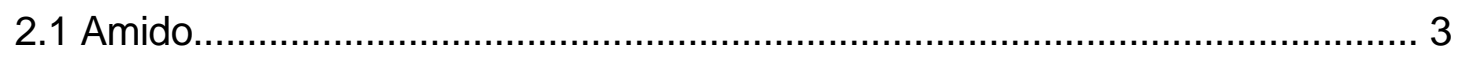

2.1.1 Amido e processamento de grãos........................................................... 3

2.1.2 Fermentação ruminal do amido, produção e metabolismo de AGVs e proteína microbiana............................................................................. 4

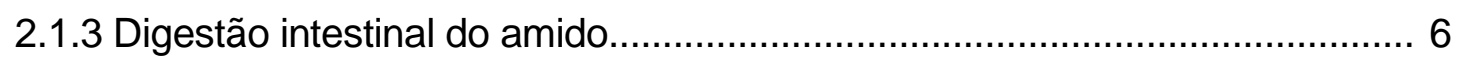

2.2 Processamento de grãos de cereais e desempenho de vacas leiteiras............ 8

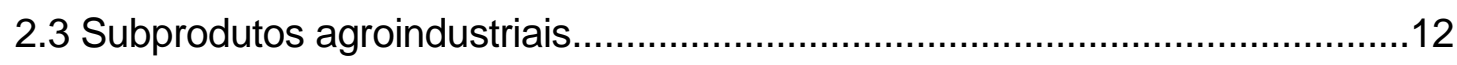

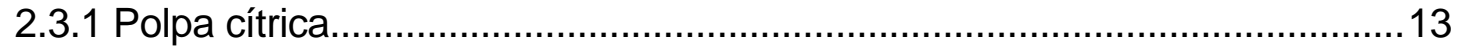

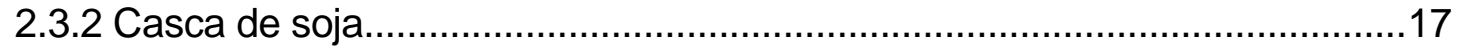

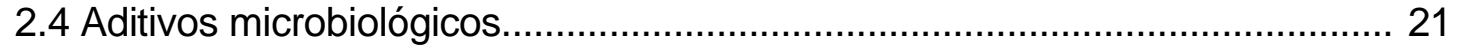

3 ADITIVO MICROBIOLÓGICO (Saccharomyces cerevisiae) E SUBSTITUIÇÃO PARCIAL DO MILHO MOÍDO POR POLPA CÍTRICA PELETIZADA EM RAÇÕES PARA VACAS LEITEIRAS EM FINAL DE

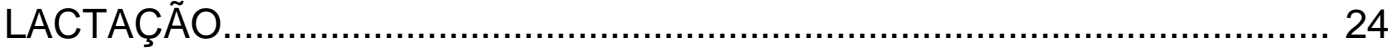

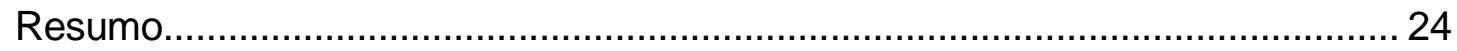

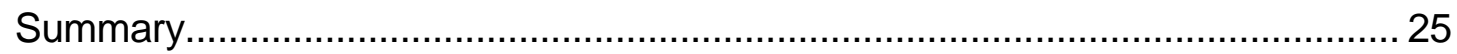

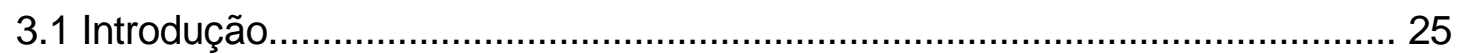

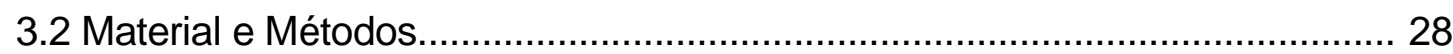




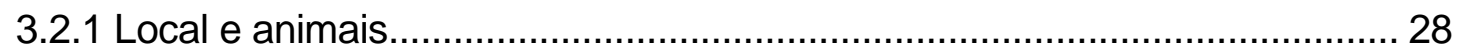

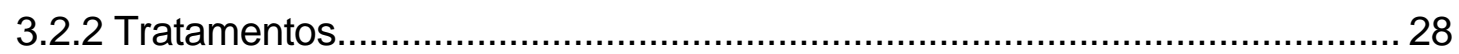

3.2.3 Período experimental e coleta de dados.................................................. 29

3.2.4 Delineamento experimental e análise estatística.................................... 31

3.3 Resultados e Discussão........................................................................ 32

3.3.1 Ingestão de matéria seca................................................................. 35

3.3.2 Produção de leite.............................................................................. 36

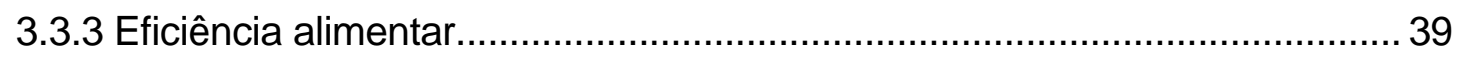

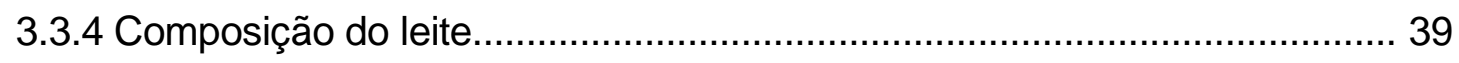

3.4.5 Nitrogênio uréico e glicose no plasma sangüíneo..................................... 43

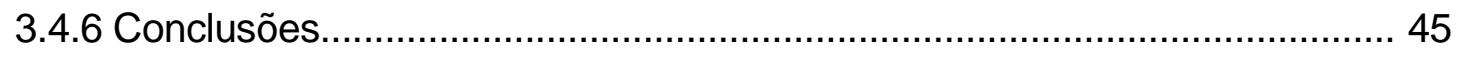

4 VARIAÇÃO DO TEOR DE AMIDO EM RAÇÕES DE VACAS LEITEIRAS ATRAVÉS DE DIFERENTES PROPORÇÕES DE MILHO MOÍDO E POLPA CÍTRICA PELETIZADA ......................................................... 46

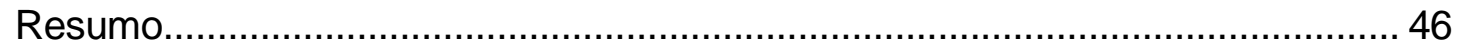

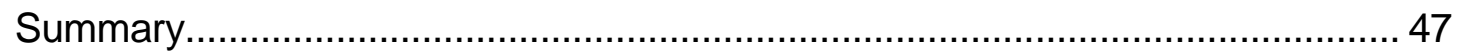

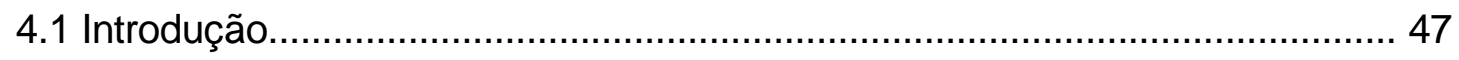

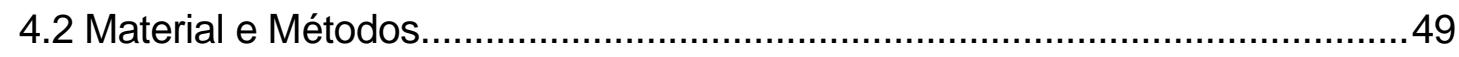

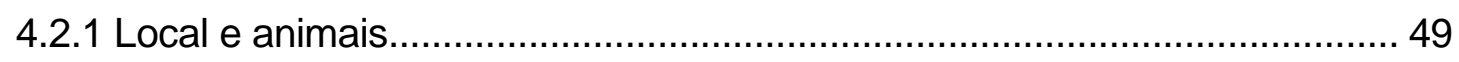

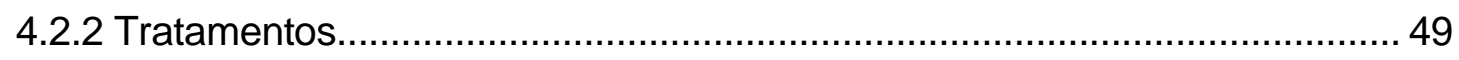

4.2.3 Período experimental e coleta de dados..................................................... 50

4.2.4 Delineamento experimental e análise estatística........................................ 52

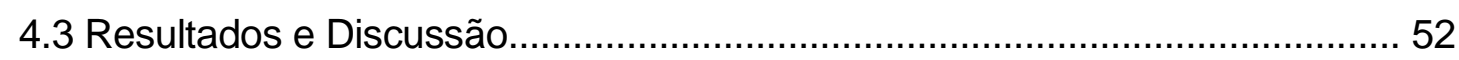

4.3.1 Ingestão de matéria seca.............................................................. 55

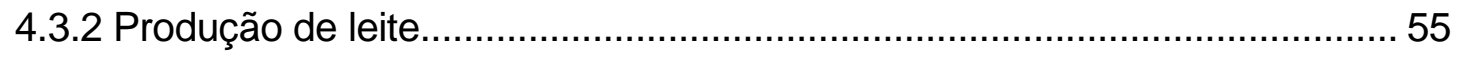

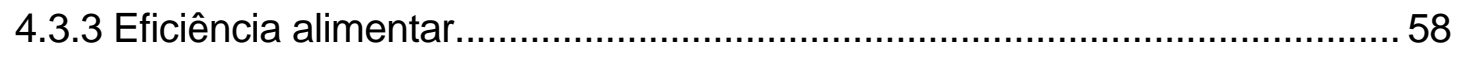

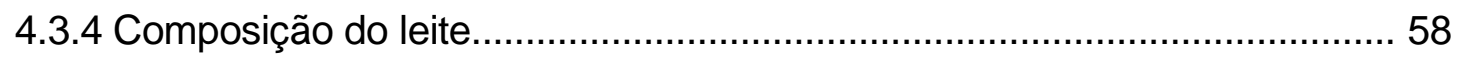

4.3.5 Nitrogênio uréico e glicose no plasma sangüíneo.................................... 60

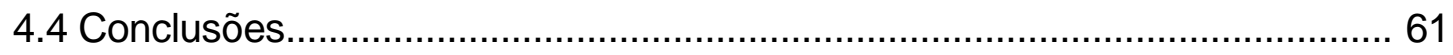


5 GRAU DE MOAGEM DO MILHO EM COMBINAÇÃO COM POLPA CÍTRICA PELETIZADA OU CASCA DE SOJA EM RAÇÕES PARA VACAS LEITEIRAS NO TERÇO MÉDIO DA LACTAÇÃO...........................6 62

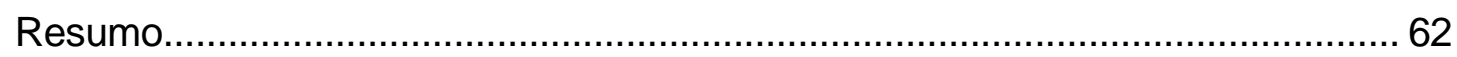

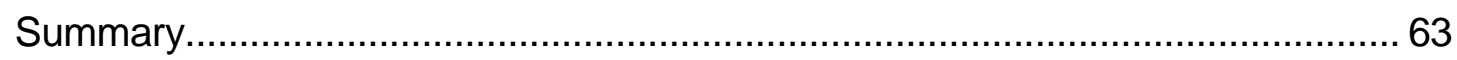

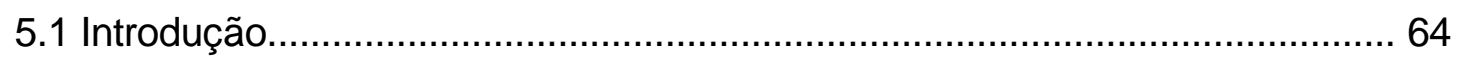

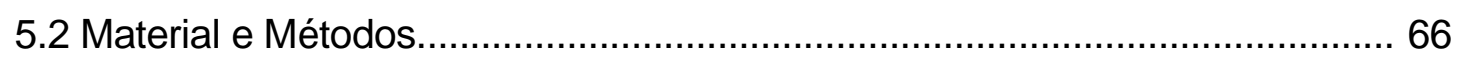

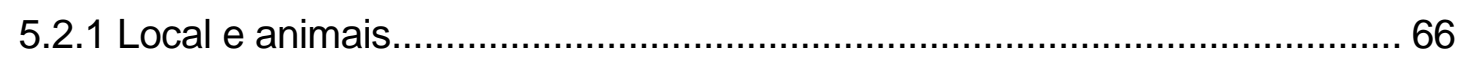

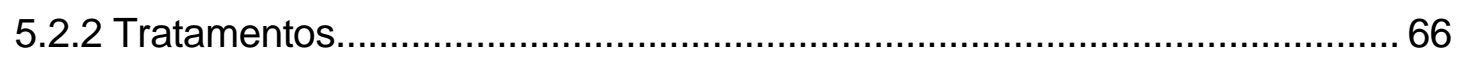

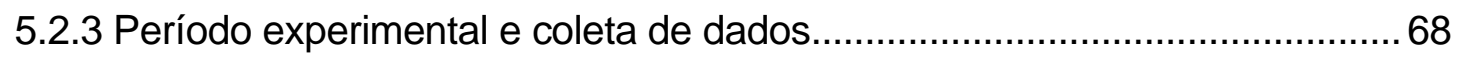

5.2.4 Delineamento experimental e análise estatística........................................ 70

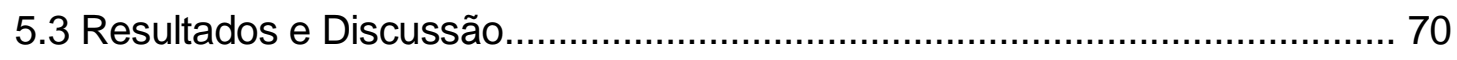

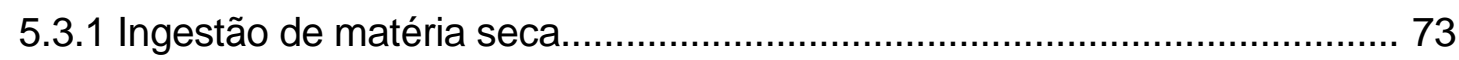

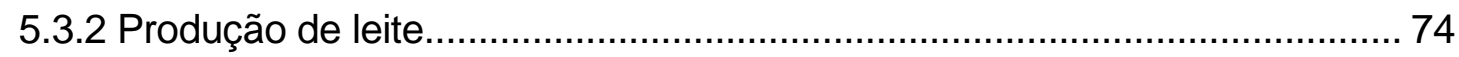

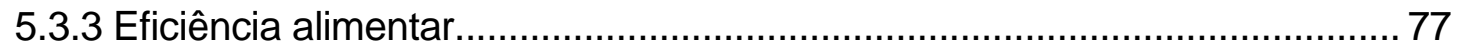

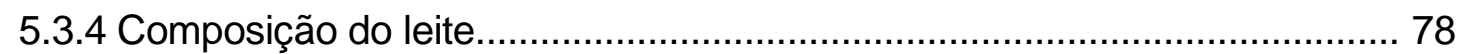

5.3.5 Nitrogênio uréico e glicose no plasma sangüíneo..................................... 80

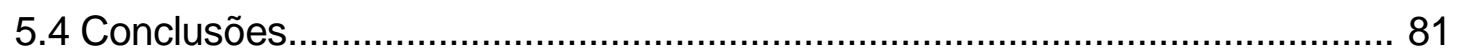

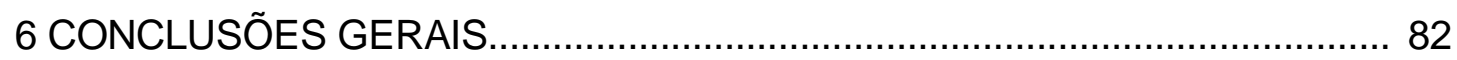

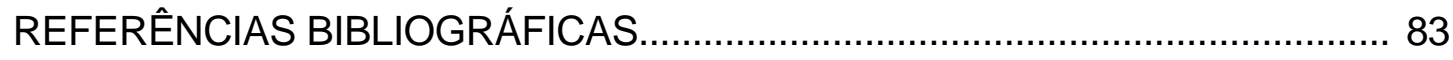




\title{
GRAU DE MOAGEM DO MILHO, INCLUSÃO DE SUBPRODUTOS AGROINDUSTRIAIS E ADITIVO MICROBIOLÓGICO EM RAÇÕES PARA VACAS LEITEIRAS
}

\author{
Autor: CAROLINA DE ALMEIDA CARMO
}

Orientador: Prof. Dr. FLÁVIO AUGUSTO PORTELA SANTOS

\section{RESUMO}

Foram realizados três experimentos para avaliar o grau de moagem do milho, sua substituição por subprodutos agroindustriais e o fornecimento de aditivos microbiológicos em rações para vacas leiteiras recebendo silagem de milho como volumoso. Experimento 1: Foram utilizadas trinta e seis vacas da raça Holandesa (330 DEL) para avaliar o fornecimento de aditivo microbiológico (Levucell SC20 da Lallemand Animal Nutrition) em rações com ou sem substituição parcial (50\%) de milho finamente moído por polpa cítrica. Foi utilizado delineamento em Quadrados Latinos $4 \times 4$ repetidos. A ingestão de matéria seca, produção e composição do leite e teor de glicose plasmática não foram afetadas $(P>0,05)$ pelos tratamentos. O nitrogênio uréico no leite foi maior $(P<0,05)$ nos animais que receberam aditivo microbiológico. O nitrogênio uréico no plasma foi reduzido pela substituição parcial do milho pela polpa cítrica $(P<0,05)$. A substituição parcial do milho por polpa cítrica não teve efeito negativo sobre o desempenho de vacas produzindo em média $19 \mathrm{~kg} / \mathrm{d}$ de leite. Experimento 2: Foram utilizadas vinte e oito vacas da raça Holandesa (230 DEL) para avaliar os efeitos de vários teores de amido na matéria seca da 
ração sobre o desempenho lactacional dos animais. O teor de amido variou através da substituição do milho moído fino pela polpa cítrica. Os tratamentos foram: 15\% (AM15), 20\% (AM20), 25\% (AM25) e 30\% de amido (AM30). Foi utilizado delineamento em Quadrados Latinos 4x4 repetidos. As produções de leite foram 27,94; 29,17; 31,11 e 29,64 kg/d para os tratamentos AM15, AM20, AM25 e AM30, respectivamente, apresentando efeito cúbico significativo $(P<0,05)$. Para produção de gordura, proteína, lactose e sólidos totais do leite também houve efeito cúbico $(P<0,05)$. Para teor de proteína, sólidos totais e nitrogênio uréico no leite houve efeito linear $(P<0,05)$. Não houve efeito dos tratamentos sobre teor de gordura do leite e glicose e nitrogênio uréico plasmáticos $(P>0,05)$. Vacas produzindo em torno de $30 \mathrm{~kg} / \mathrm{d}$ apresentaram melhor desempenho quando alimentadas com rações contendo $25 \%$ de amido, não havendo vantagem no fornecimento de rações com teor de amido de $30 \%$. Experimento 3: Foram utilizadas trinta e duas vacas da raça Holandesa (160 DEL) para comparar o grau de moagem do milho (fino ou grosso) em combinação com polpa cítrica peletizada ou casca de soja nas rações. Os tratamentos foram: milho moído fino + polpa cítrica (MFPC), milho moído grosso + polpa cítrica (MGPC), milho moído fino + casca de soja (MFCS), milho moído grosso + casca de soja (MGCS). Foi utilizado delineamento em Quadrados Latinos $4 \times 4$ repetidos. A ingestão de matéria seca, produção de leite, teores de gordura, proteína e lactose do leite, glicose e nitrogênio uréico plasmáticos não foram afetados pelos tratamentos $(P>0,05)$. Houve efeito significativo da interação grau de moagem versus tipo de subproduto $(P<0,05)$ para produção de leite corrigido para gordura, produção de gordura e de sólidos totais do leite. O grau de moagem do milho e o tipo de subproduto não afetaram o desempenho de vacas leiteiras com produção ao redor de 24 kg/d. 


\title{
CORN GRAIN GRINDING, AGRICULTURE INDUSTRIAL BYPRODUCTS AND YEAST CULTURE IN DAIRY COW RATIONS
}

\author{
Author: CAROLINA DE ALMEIDA CARMO \\ Adviser: Prof. Dr. FLÁVIO AUGUSTO PORTELA SANTOS
}

\section{SUMMARY}

Three experiments were conducted to assess the effects of corn grain grinding, byproducts and yeast culture supplementation in dairy cow rations containing corn silage as forage. Experiment 1: Thirty six lactating Holstein cows (330 days in milk - DIM) were used to study the supplementation of yeast culture (Levucell SC20 - Lallemand Animal Nutrition) in dairy rations with partial (50\%) replacement of finely ground corn by dried citrus pulp. A repeated $4 \times 4$ Latin Square design was used. Dry matter intake, milk yield and composition and plasma glucose were not affected $(P>0,05)$ by treatments. Milk urea nitrogen was raised by yeast culture supplementation $(P<0,05)$. Plasma urea nitrogen was reduced by feeding citrus pulp in partial replacement of corn $(P<0,05)$. The partial replacement of finely ground corn by dried citrus pulp did not affect the cows performance with $19 \mathrm{~kg} / \mathrm{d}$ milk yield. Experiment 2: Twenty eight lactating Holstein cows (230 DIM) were used to evaluate the effects on performance of varying contents of starch in the ration. Starch contents was varied by replacing fine ground corn by dried citrus pulp. Treatments were: 15\% (AM15), 20\% (AM20), 25\% (AM25) e 30\% of starch (AM30) in the ration dry matter. A repeated 4x4 Latin Square design was used. Milk yield was 27,94; 29,17; 31,11 
e 29,64 kg/d for treatments AM15, AM20, AM25 and AM30, respectively, with cubic effect $(P<0,05)$. Milk fat, protein, lactose and total solids yield were affected cubically $(P<0,05)$. Linear effects were detected for protein, total solids and milk urea nitrogen contents $(P<0,05)$. Milk fat contents, plasma urea nitrogen and glucose were not affected by treatments $(P>0.05)$. Cows producing about $30 \mathrm{~kg} / \mathrm{d}$ got better performance when fed with rations 25\% starch contents. Did not have advantage by supplying 30\% starch contents rations. Trial 3: Thirty two mid lactating Holstein cows (160 DIM) were used to study the effects on performance of corn grain grinding (coarse or fine) and its combination with dried citrus pulp or soy hulls. A repeated $4 \times 4$ Latin Square design was used. The treatments were: fine ground corn + citrus pulp (MFPC), coarse ground corn + citrus pulp (MGPC), fine ground corn + soy hulls (MFCS), coarse ground corn + soy hulls (MGCS). Treatments did not affect DMI, milk yield, milk fat, protein and lactose contents, plasma urea $\mathrm{N}$ and glucose $(P>0.05)$. The interaction corn grain grinding and byproduct source was significative for fat corrected milk, fat and total solids yield $(P<0,05)$. Corn grain grinding and byproduct variety did not affect the cows performance with $24 \mathrm{~kg} / \mathrm{d}$ milk yield. 


\section{INTRODUÇÃO}

Os grãos de cereais como milho, sorgo, milheto, aveia, trigo e cevada, são algumas das principais fontes de energia em rações para vacas leiteiras. Maximizar a digestibilidade destes cereais é uma das formas mais eficientes para se aumentar o consumo de energia do animal e, conseqüentemente, o seu desempenho.

Uma alternativa para se aumentar a digestibilidade dos grãos de cereais é o processamento desses materiais. Diversos trabalhos mostraram as vantagens do processamento dos grãos de cereais para vacas em lactação (Chen et al., 1994; Chen et al., 1995a b; Moore et al., 1992; Oliveira et al., 1993; Poore et al., 1993b; Santos et al.,1997; Simas et al.,1994, 1995; Theurer et al., 1991; Yu et al., 1994, 1995, entre outros). Um aspecto que merece atenção é que, na maioria destes trabalhos, a fonte de alimento volumoso utilizado foi o feno de alfafa, pouco comum nos sistemas de produção brasileiros.

No Brasil, a silagem de milho tem sido a fonte de forragem mais utilizada em rações para vacas leiteiras mantidas em confinamento total. Raros são os trabalhos publicados onde se avaliou teores de amido total e amido degradável no rúmen em rações para vacas leiteiras de alta produção, alimentadas com silagem de milho como único volumoso.

Até o momento não se pode afirmar de forma definitiva se existe um teor ideal de amido total e de amido degradável no rúmen em rações para vacas leiteiras, cujo volumoso principal seja a silagem de milho, devido às características desse alimento em termos de composição e fermentação ruminal, ou seja, a silagem de milho tem alto teor de amido de alta 
degradabilidade, e a fermentação da mesma propicia baixo $\mathrm{pH}$ ruminal. Também precisam ser melhor estudados os efeitos da redução no teor de amido na ração sobre o desempenho de vacas leiteiras, através da substituição dos grãos de cereais por subprodutos agroindustriais, como polpa cítrica e casca de soja. O uso de subprodutos pode se constituir em alternativa interessante, uma vez que normalmente permite diminuir os custos com alimentação dentro do sistema de produção.

O interesse pela suplementação de aditivos microbiológicos para vacas leiteiras tem crescido nos últimos anos. Estabilização do pH ruminal, maior digestão de frações fibrosas dos alimentos, maior consumo e aumento na síntese microbiana têm sido apontados como prováveis responsáveis pela melhora no desempenho observada em alguns, mas não em todos os estudos, onde o aditivo microbiológico tem sido utilizado. De um modo geral, apesar da grande variabilidade dos resultados, observou-se aumento de produção de leite e melhora na sua composição. Tem sido sugerido que vacas sob estresse térmico e recebendo rações com alto teor de amido teriam maiores chances de responder a este tipo de aditivo (Arambel \& Kent,1990).

Dentro desse contexto, mais informações são necessárias sobre o desempenho de vacas em lactação recebendo rações com diferentes teores de amido total e de amido degradável no rúmen, através da substituição do milho por subprodutos agroindustriais e do processamento do milho, assim como o efeito de aditivo microbiológico (Saccharomyces cerevisiae) sendo fornecido juntamente com esses tipos de rações. 


\section{REVISÃO DE LITERATURA}

\subsection{Amido}

\subsubsection{Amido e processamento de grãos}

Os carboidratos não fibrosos são, em geral, hidrossolúveis e representados por açúcares, amido e pectina. O amido representa de 70 a $80 \%$ dos grãos de cereais e é composto por dois tipos de moléculas: amilose e amilopectina. A amilose é um polímero linear de unidades de D-glicose, e a amilopectina é um polímero ramificado com cadeias lineares de D-glicose (Nocek \& Tamminga, 1991).

O amido dos diferentes grãos de cereais contém proporções diferentes de amilose e amilopectina, sendo este um dos fatores que afetam sua digestibilidade, uma vez que a amilose é menos digestível que a amilopectina. Além dos teores de amilose e amilopectina, o tipo de grão de cereal, a camada externa do grânulo, a presença da matriz protéica revestindo este grânulo e o método de processamento do grão também afetam a digestibilidade do amido (Theurer et al., 1999a).

Os tipos de processamento mais freqüentemente utilizados em grãos de cereais são: moagem, laminação, laminação a vapor (mecânicos), micronização, pipoca, tostagem (calor a seco), colheita precoce, reconstituição (processamento úmido), explosão, floculação e floculação sob pressão (processamento com vapor). Os métodos mais eficientes para aumentar a digestibilidade do amido dos grãos são a floculação, micronização, pipoca, 
reconstituição seguida de moagem e colheita precoce seguida de moagem, de acordo com Simas (1996).

Quando estudaram o efeito do nível de ingestão de matéria seca (MS) sobre o valor nutritivo do milho laminado a seco, comparado ao milho floculado, Zinn et al. (1995) concluíram que o processamento do milho é o primeiro fator que influencia o local e a extensão da digestão de amido. A floculação aumentou a energia líquida de manutenção e de ganho do milho.

A principal forma de processamento de grãos de cereais para bovinos no Brasil é a moagem. Esse processamento aumenta a degradabilidade do amido no rúmen e sua digestibilidade no trato digestivo total, devido a um rompimento da matriz protéica e aumento da área superficial. A moagem fina dos grãos de milho tem resultado em valores de digestibilidade do amido maiores que a laminação, porém menores que a floculação e que o material colhido precocemente e ensilado (Huntington, 1997; Theurer et al, 1999a).

\subsubsection{Fermentação ruminal de amido, produção e metabolismo de ácidos graxos voláteis e proteína microbiana}

O principal local de fermentação do amido é o rúmen. Essa fermentação se dá pela ação das enzimas bacterianas. Os fatores mais importantes que afetam a degradação do amido no rúmen, segundo Theurer (1986) são a fonte de grão de cereal e o processamento do grão. Huntington (1997) relatou que, comparada com a laminação a seco ou moagem grosseira, a floculação pode aumentar a digestibilidade ruminal do amido de 52 para $78 \%$ para o grão de sorgo e de 75 para $85 \%$ para o grão de milho.

Bactérias amilolíticas e dextrinolíticas hidrolisam o amido, resultando em maltose e glicose, que são fermentadas por bactérias sacarolíticas, produzindo piruvato, ATP e $\mathrm{NADH}_{2}$. Como resultado da fermentação do piruvato formam-se ácidos graxos voláteis (AGVs), $\mathrm{CO}_{2}$ e $\mathrm{CH}_{4}$. Os principais $\mathrm{AGVs}$ produzidos são acetato, butirato e propionato, sendo que a proporção com que estes são 
produzidos varia com o tipo de ração. Rações com alto teor de amido degradável no rúmen levam a altas proporções propionato:acetato. Em geral, as proporções de acetato:propionato:butirato variam de 75:15:10 a 40:40:20 (Bergman, 1990).

É provável que a totalidade dos AGVs produzidos seja absorvida através da parede dos compartimentos estomacais: rúmen, retículo e omaso. Entretanto, determinados AGVs são extensamente metabolizados durante a absorção. Em vacas leiteiras, por exemplo, 90\% do butirato é metabolizado a $\mathrm{CO}_{2}$ e $\beta$-hidroxibutirato. Em menores proporções, acetato é metabolizado a $\mathrm{CO}_{2}$. Vacas leiteiras apresentam baixo metabolismo de propionato durante sua absorção, poupando este composto para a gluconeogênese hepática (Reynolds et al., 1988a b; 1994). Estes autores relataram que apenas 10 a 15\% do propionato produzido no rúmen é utilizado pelo trato intestinal e mais de $90 \%$ do propionato absorvido pelo sistema porta é utilizado pelo fígado na gluconeogênese.

O metabolismo de AGVs pelo fígado e tecidos viscerais é determinado pela atividade das enzimas CoA sintetases nos diferentes tecidos. Os tecidos periféricos apresentam alta atividade da enzima acetil CoA sintetase, sendo portanto grandes utilizadores de acetato. O fígado, principal local de produção de glicose (gluconeogênese) nos bovinos, apresenta elevada atividade da enzima propionil CoA sintetase, ao passo que a parede ruminal tem elevada atividade da enzima butiril CoA sintetase. Aproximadamente 15 a 20\% do "turnover" do acetato é utilizado pelos tecidos drenados pelo sistema porta e o restante pelos tecidos periféricos, como fonte de energia e para síntese de gordura. Do total de butirato produzido no rúmen cerca de $10 \%$ chega ao fígado de vacas leiteiras, sendo que $68 \%$ do fluxo portal total de butirato é utilizado no fígado, formando ácidos graxos de cadeia longa, corpos cetônicos e $\mathrm{CO}_{2}$.

A produção de proteína microbiana e a passagem de nitrogênio para o intestino delgado podem ser influenciadas, além de outros fatores, pela fonte e degradabilidade ruminal dos carboidratos não fibrosos, principalmente o amido. 
Herrera-Saldana et al. (1990) observaram em vacas leiteiras que tanto a eficiência como a produção microbiana foram superiores quando a degradabilidade ruminal do amido foi aumentada através da substituição de grãos de sorgo por grãos de cevada.

Quando a degradabilidade ruminal do amido foi aumentada devido ao processo de floculação do grão de sorgo, a eficiência microbiana (matéria microbiana/kg de matéria orgânica degradada) não foi afetada, mas a produção de proteína microbiana foi superior para o sorgo floculado do que para o sorgo laminado a seco (Oliveira et al., 1995; Poore et al., 1993a).

Strobel \& Russel (1986) mostraram que a eficiência microbiana "in vitro" não foi afetada pela fonte de carboidrato, e Hoover \& Stokes (1991) também observaram que a eficiência microbiana não foi afetada quando a proporção de carboidrato não estrutural, como porcentagem do carboidrato total, foi aumentada na ração.

Huber \& Herrera-Saldana (1994) discutiram os benefícios da sincronização das taxas de degradação de carboidrato e proteína no rúmen para maximizar a síntese microbiana e a fermentação ruminal, enquanto Hoover \& Stokes (1991) sugeriram que a máxima digestão de MS, eficiência microbiana e produção de proteína microbiana seriam obtidas em rações contendo 10 a $13 \%$ de proteína degradável no rúmen e $56 \%$ do carboidrato total como carboidrato não estrutural.

\subsubsection{Digestão intestinal de amido}

A digestão do amido no intestino delgado começa com a secreção de $\alpha$ amilase pelo pâncreas, que hidrolisa a amilose e a amilopectina em dextrinas e oligossacarídeos lineares (Gray, 1991; Harmon, 1992). As oligossacaridases, presentes na borda em escova das microvilosidades intestinais, completam o processo, produzindo glicose para a absorção. Como a atividade da sucrase em 
ruminantes não é mensurável, a produção de glicose para a absorção depende da atividade da maltase e isomaltase (Harmon, 1992).

Acredita-se que a digestão do amido no intestino delgado possa ser limitada por falta de $\alpha$ amilase e isomaltase ou por uma capacidade limitada de absorção de glicose. Huntington (1997) defende a hipótese da limitação enzimática e afirma não haver limitação à absorção intestinal de glicose. No entanto, Owens et al. (1986) sugeriram que o tempo de permanência no intestino e a área de exposição dos grãos podem ser os fatores mais limitantes à digestão do amido no intestino. Alguns dados (Theurer, 1986) indicam que o intestino delgado tem grande capacidade para digerir o amido. Entretanto, conforme aumenta a quantidade de amido que chega ao intestino, a eficiência da digestão intestinal do amido decresce (Nocek \& Tamminga, 1991).

A digestibilidade aparente no trato total do amido foi aumentada pela moagem do milho quando comparada à digestibilidade observada com o milho quebrado, fornecidos para vacas leiteiras em início de lactação, de acordo com Knowlton et al. (1996). O milho moído teve digestibilidade de 92,1\% e o milho quebrado de 85,6\%.

Estudos têm sido conduzidos com o objetivo de ampliar o conhecimento sobre o metabolismo de glicose após a sua absorção intestinal. Não se sabe ao certo quais os destinos exatos da glicose resultante da digestão do amido no intestino delgado. $O$ interessante é que esses estudos têm demonstrado, de forma consistente, que o fluxo líquido de glicose no sistema porta é quase sempre negativo ou nulo em vacas lactantes. Isso indica que a absorção de glicose através da veia porta é excedida pela utilização arterial de glicose, sugerindo extenso uso pelos tecidos drenados pelo sistema porta, e que a gluconeogênese hepática responde por toda a glicose utilizada pela glândula mamária e tecidos periféricos (Huntington, 1997; Reynolds et al., 1994; Theurer et al., 1999a).

Apesar da constatação de Owens et al. (1986) de que o amido digerido no intestino delgado é $42 \%$ mais eficiente energeticamente, que foi corroborada 
por Nocek \& Tamminga (1991), estes últimos autores concluíram que não havia, até então, evidências na literatura de que um aumento da digestão do amido no intestino, em detrimento da fermentação ruminal, levasse a maiores produções de leite ou de componentes do leite. Huntington (1997), Lykos \& Varga (1997) e Theurer et al. (1999a) encontraram melhores respostas em termos de desempenho e metabolismo animal, quando maior parte do amido foi degradada no rúmen.

Caso escape à fermentação ruminal e à digestão enzimática no intestino delgado, o amido pode ainda ser degradado no intestino grosso. Entretanto, a fermentação no intestino grosso representa uma perda para o animal no que diz respeito à utilização de nitrogênio, uma vez que a proteína microbiana sintetizada não pode ser absorvida, além disso, parte do nitrogênio que poderia ser reciclado e, assim, voltar para o rúmen, vai ao intestino grosso.

\subsection{Processamento de grãos e desempenho de vacas leiteiras}

Vários trabalhos têm sido realizados para avaliar os efeitos da moagem do grão de milho sobre o desempenho de vacas leiteiras. Knowlton et al. (1996) forneceram milho quebrado ou moído para vacas leiteiras no início da lactação, e observaram que os animais que receberam milho moído perderam menos condição corporal e tiveram o teor de protéina do leite aumentado. A produção de leite tendeu a aumentar com a moagem do milho. Também houve aumento na digestibilidade do amido no trato digestivo total. Resultados semelhantes foram obtidos por Knowlton et al. (1998), que compararam moagem e laminação como métodos de processamento do milho, e observaram tendência de aumento da produção de leite, aumento da proteína e lactose do leite, resultado da moagem.

Wilkerson et al. (1997) testaram as combinações milho seco moído ou laminado, e milho ensilado úmido, moído ou laminado. A produção de leite foi 2 $\mathrm{kg} / \mathrm{d}$ maior para o milho úmido e $2,2 \mathrm{~kg} / \mathrm{d}$ maior para o milho moído. O balanço 
de nitrogênio sugeriu maior eficiência de utilização da proteína degradável no rúmen nas rações contendo milho úmido. Ekinci \& Broderick (1997) encontraram resultados semelhantes, onde a moagem do milho úmido aumentou a taxa e a extensão da fermentação ruminal do amido e aumentou também a utilização do nitrogênio não protéico da silagem de alfafa. A produção de leite e a eficiência de utilização de nutrientes também foram aumentadas.

Yu et al. (1998) compararam cinco tipos de processamento de grãos: milho moído fino ou grosso, milho floculado com baixa ou média densidade e milho laminado a vapor. A produção de leite foi maior para milho floculado com média densidade (360 g/L) seguido do milho moído fino. Os piores desempenhos foram obtidos com os grãos moído grosso, laminado ou floculado excessivamente.

Em estudo realizado para avaliar o efeito do grau de moagem de três formas de milho sobre o desempenho de vacas leiteiras, a produção de leite e de proteína do leite foram maiores para o milho finamente moído (San Emeterio et al., 2000).

Callison et al. (2001) avaliaram o local de digestão de nutrientes em vacas alimentadas com milho moído com diferentes tamanhos de partículas $(4,8 ; 2,6$ ou $1,2 \mathrm{~mm})$ ou com milho laminado a vapor. A diminuição do tamanho de partícula aumentou a degradabilidade ruminal dos carboidratos não estruturais. A adição de milho laminado a vapor ao milho moído grosso aumentou a degradabilidade ruminal dos carboidratos não estruturais em vinte pontos percentuais, mas teve efeito muito menor sobre a digestibilidade no trato total.

Santos et al. (2001a) constataram vantagens na substituição do milho moído fino por uma fonte de amido mais degradável no rúmen, ou seja, o milho processado na forma de pipoca, para vacas produzindo ao redor de $32 \mathrm{~kg} / \mathrm{d}$, uma vez que vacas recebendo milho na forma de pipoca tiveram melhor eficiência alimentar. Entretanto, os teores de gordura do leite observados, tanto 
no tratamento com milho moído fino como no tratamento contendo pipoca, foram baixos.

Vinte vacas leiteiras, incluindo cinco com cânulas ruminais, foram utilizadas para avaliar a influência do processamento do milho (moagem grossa, fina ou floculação) e a influência da freqüência de alimentação sobre a produção de leite e características de fermentação ruminal, em trabalho de Dhiman et al. (2002). O processamento do milho e a freqüência de alimentação não tiveram efeito sobre a ingestão de matéria seca. Os animais que receberam milho floculado ou moído fino produziram mais leite, porém com teor de gordura mais baixo.

Nussio et al. (2002) compararam milho moído fino com moído grosso, com floculado e com a substituição parcial dessas fontes de amido por polpa cítrica peletizada em rações para vacas leiteiras. A produção de leite corrigida para teor de gordura e o teor de gordura do leite foram maiores para o tratamento com milho moído fino, comparado aquele que continha milho moído grosso.

Soriano et al. (2000) e Reis et al. (2001) não observaram efeito do grau de moagem do milho fornecido para vacas leiteiras mantidas em pastagens sobre a produção e composição do leite.

Outros métodos de processamento do milho também têm sido bastante estudados, como a floculação e a laminação. Os resultados obtidos mostram que a floculação aumenta a degradabilidade ruminal do amido e melhora o desempenho de vacas leiteiras, o que é demonstrado por aumento na produção de leite, leite corrigido para gordura, teor e produção de proteína do leite, além de maior retorno líquido por vaca em termos de leite produzido e custo de alimentação (Chen et al., 1994; Chen et al., 1995a b; Moore et al., 1992; Oliveira et al., 1993; Poore et al., 1993b; Santos et al., 1997; Simas et al.,1994, 1995; Theurer et al., 1991; Yu et al., 1994, 1995).

Avaliando a influência da densidade do floco nas características de digestão ruminal e no trato total em vacas lactantes alimentadas com rações 
com alto teor de concentrado, Plascencia \& Zinn (1996) concluíram que a floculação aumenta o valor nutritivo do milho devido ao aumento na aceitabilidade da ração e na digestibilidade do amido e do nitrogênio. Porém, o processamento excessivo do grão afetou negativamente a digestibilidade da fibra e o teor de gordura do leite.

Yu et al. (1997) também avaliaram os efeitos do processamento do milho, observando que a floculação aumentou a produção de leite, o seu teor e a sua produção de proteína, lactose e sólidos não gordurosos e ainda aumentou a eficiência de conversão de MS consumida em leite corrigido para gordura, quando comparada à laminação a vapor. Santos et al. (1999b) encontraram resultados semelhantes quando avaliaram a resposta de vacas em lactação alimentadas com sorgo floculado, milho floculado ou milho laminado a vapor e fontes protéicas de diferentes degradabilidades. Os animais alimentados com grão floculado produziram $1,5 \mathrm{~kg} / \mathrm{d}$ de leite a mais, produziram mais proteína e tiveram maior teor de lactose e sólidos não gordurosos do leite.

Em rações com diferentes proporções de milho laminado a seco e floculado, a degradabilidade ruminal do amido e as digestões pós ruminal e no trato total aumentaram linearmente conforme a proporção de milho laminado diminuiu. No entanto, a produção e composição do leite foram similares entre as rações (Crocker et al., 1998).

Santos et al. (1999a) compararam produção e composição do leite e digestibilidade de nutrientes de vacas recebendo somatrotopina bovina (BST), ao serem alimentadas com rações com fontes de amido de diferentes degradabilidades ruminais (sorgo floculado ou milho laminado a vapor) e concluíram que os animais responderam melhor ao BST quando alimentados com rações contendo sorgo floculado.

Shabi et al. (1999) avaliaram o efeito da extrusão do milho e da freqüência de alimentação sobre a digestibilidade e a produção de leite. A extrusão aumentou a digestibilidade pós ruminal dos carboidratos não estruturais, reduziu a ingestão de MS e produção de leite e aumentou a 
eficiência de síntese de energia e proteína do leite. Com o aumento da freqüência de alimentação, a ingestão de MS e a digestibilidade dos nutrientes foram aumentadas.

De acordo com os diversos trabalhos revisados por Theurer et al. (1999a), para vacas leiteiras, a densidade ideal para a floculação do milho ou sorgo está ao redor de 360g/L.

A alimentação com milho laminado a vapor melhorou a condição corporal e a ruminação em trabalho de Uchida et al. (2001), no qual estudaram o efeito da variação na proporção de milho moído e milho laminado a vapor sobre o desempenho de vacas em lactação. A substituição parcial ou completa do milho moído pelo milho laminado a vapor não melhorou a digestão dos nutrientes nem a produção de leite.

\subsection{Subprodutos agroindustriais}

A maioria dos trabalhos publicados na literatura internacional, principalmente na América do Norte, utilizaram feno ou silagem de alfafa como principal volumoso das rações onde o processamento de milho ou sorgo foi testado. Vacas de alta produção no Brasil são normalmente confinadas com rações contendo silagem de milho como o principal volumoso. A silagem de milho de boa qualidade tem em torno de 26 a 32\% de amido na sua composição.

Santos et al. (2001b) e Nussio et al. (2002) sugerem que os teores de amido total e de amido degradável no rúmen propostos como adequados nos trabalhos revisados por Theurer et al. (1999a), contendo alfafa como principal fonte de forragem, podem ser excessivos quando o volumoso é principalmente silagem de milho. Isso se deve às características desse alimento em termos de composição e fermentação ruminal, ou seja, a silagem de milho tem alto teor de amido de alta degradabilidade e a fermentação da mesma propicia baixo pH ruminal. 
A substituição parcial do milho por subprodutos não amiláceos ricos em pectina e fibra digestível, como a polpa cítrica e a casca de soja, pode ser uma alternativa viável para reduzir o teor de amido da ração, melhorar o ambiente ruminal e manter ou melhorar a produção e a composição do leite.

\subsubsection{Polpa cítrica}

Desde a década de 70 até início dos anos 90, cerca de 95\% da polpa cítrica produzida no Brasil era exportada para a Europa, sendo um alimento praticamente desconhecido pelos pecuaristas nacionais. Devido à menor demanda do produto no mercado internacional, com queda de preço do mesmo, as indústrias necessitaram direcionar grande parte da produção de polpa para o mercado interno (Carvalho, 1995). O Brasil hoje é o principal produtor mundial de polpa cítrica, com produção anual estimada de 1.150 .000 de toneladas (Santos et al., 2004a).

Estima-se que a polpa cítrica possui cerca de 85 a $90 \%$ do valor energético do milho, não sendo uma boa fonte protéica (NRC, 1989; Stern \& Ziemer, 1993). Seu teor de carboidratos solúveis é alto, entre 25 a 35\% da MS (Waiman \& Dewey, 1988; Faria et al., 1972). De acordo com Deaville et al. (1994), a polpa cítrica possui teor de amido muito baixo, em torno de 0,5\%. A polpa pode ser classificada como sendo um concentrado energético, mas considerando seu comportamento fermentativo no rúmen, situa-se entre volumoso e concentrado (Fegeros et al., 1995).

A pectina, representativa na composição da MS da polpa cítrica, é um carboidrato constituído por polímeros de ácido galacturônico e sua degradação ruminal é muito rápida (Van Soest et al., 1991; Schultz et al., 1991), com taxas de 30 a 50\%/h, segundo Sniffen (1988) e Chesson \& Monro (1982), e quase completa (90 a 100\%), de acordo com Nocek \& Tamminga (1991) e Stern \& Ziemer (1993). 
A fermentação ruminal da pectina aumenta a produção de acetato e diminui a de lactato. Pode também melhorar a digestão da fibra do volumoso, por evitar a queda de $\mathrm{pH}$, criando ambiente ruminal favorável (Van Soest, 1987; Van Soest, 1994; Reinato et al., 2002). A polpa cítrica contribuiu para a elevação da produção de ácido acético, aumentando a relação acético:propiônico no rúmen (Loggins et al., 1964; Hentges et al., 1966).

Em rações para animais de alta produção, onde o teor de alimentos concentrados é elevado, o ambiente ruminal pode ser prejudicado com efeitos deletérios na manutenção da motilidade ruminal e estímulo à ruminação, devido à deficiência de fibra na ração. A substituição de parte do amido por polpa cítrica peletizada permite elevar o nível de fibra na ração e ainda manter adequada a disponibilidade de carboidrato degradável no rúmen, de acordo com Giardini (1993). Apesar do médio teor de fibra em detergente ácido (FDA) (por volta de 24\%), a polpa cítrica tem baixo teor de lignina (1\%), sendo quase toda a fibra digerida no rúmen, uma vez que a celulose representa aproximadamente $23 \%$ da matéria seca da polpa, e é altamente digerida pelos microrganismos ruminais (Orskov, 1987).

Em trabalho de Schaibly \& Wing (1974), a polpa cítrica substituiu a silagem de milho nos teores de 0\%, 33\%, 67\% e 100\% em base de MS, em rações para novilhos. A digestibilidade da MS aumentou com o teor de $67 \%$ de substituição. A proporção molar de acido acético, uma e duas horas após a alimentação, foi maior para o tratamento com teor de $100 \%$ de substituição. Os valores de $\mathrm{pH}$ mais baixos observados foram 6,81 e 6,75 para os tratamentos com teores de $67 \%$ e 100\% de substituição, respectivamente.

Conforme Wing (1982) constatou em sua revisão, a inclusão de polpa cítrica em até $60 \%$ do concentrado $(0 \%, 10 \%, 20 \%, 30 \%, 40 \%$ e $60 \%)$ não afetou a digestibilidade da MS, da proteína e o balanço de AGVs no rúmen de novilhos.

Em experimento conduzido por Valk et al. (1990), as perdas de amônia no rúmen foram menores em ração com polpa de beterraba (semelhante à 
polpa cítrica) em comparação ao milho, sugerindo que os microrganismos do rúmen capturaram mais amônia proveniente da degradação da proteína da forragem quando a polpa foi fornecida.

A utilização do nitrogênio pode ser mais eficiente em rações contendo alimentos ricos em pectina, como a polpa cítrica e a de beterraba, de acordo com McCullough (1995), que observou teor de nitrogênio uréico no plasma significativamente menor na ração com alto teor de polpa cítrica do que naquela que continha milho. O autor sugere que houve maior retenção $e$, consequentemente, utilização mais eficiente da proteína pelos animais que receberam a polpa cítrica, uma vez que os teores de amônia ruminal eram iguais.

A inclusão de polpa cítrica aumentou a proporção molar de acetato e diminuiu a de propionato ruminal de vacas canuladas, em trabalho de Rocha Filho (1998), que estudou o efeito da substituição da silagem de milho por diferentes quantidades de polpa cítrica peletizada, milho ou combinação de milho e polpa sobre alguns parâmetros ruminais. Os resultados de produção total de AGVs, pH e amônia ruminal e nitrogênio uréico no plasma sangüíneo não foram diferentes entre os tratamentos.

Para vacas de alta produção, a polpa cítrica levou a maiores ingestões de MS, maior teor de gordura no leite e maior produção de leite corrigido para gordura quando combinada com silagem de milho do que quando combinada com alfafa peletizada, conforme observado por Drude et al. (1971).

Lucci et al. (1975) observaram aumento do teor de gordura e da produção de leite corrigida para gordura quando substituíram milho por polpa cítrica em rações de vacas leiteiras de baixa produção $(13 \mathrm{~kg} / \mathrm{d})$.

Van Horn et al. (1975) incluíram polpa cítrica em teores de 8\% e 43\% em rações de vacas leiteiras. A ração com $43 \%$ de polpa cítrica resultou em maior teor de gordura do leite.

Belibasakis \& Tsirgogianni (1996) forneceram 20\% do concentrado como polpa cítrica em rações de vacas leiteiras que continham silagem de milho 
como volumoso. A ingestão de $\mathrm{MS}$, produção de leite, teor e produção de proteína e lactose do leite não foram afetados pelos tratamentos. Mas, a inclusão de polpa aumentou o teor e a produção de gordura do leite. Não foi observado efeito sobre os teores plasmáticos de glicose e nitrogênio uréico.

Solomon et al. (2000) avaliaram rações com alto teor de amido (proporção milho:polpa de 70:30) ou com alto teor de pectina (proporção milho:polpa de 30:70) e não observaram diferenças na produção de leite, no teor e produção de gordura do leite e no teor de lactose e nitrogênio uréico no leite. A produção média de leite foi de $35 \mathrm{~kg} / \mathrm{d}$. O teor e produção de proteína do leite foram maiores para o tratamento com maior proporção de milho.

O efeito da substituição do milho por polpa cítrica sobre a produção de leite e sobre a fermentação ruminal foi avaliado por Leiva et al. (2000). As vacas alimentadas com milho apresentaram maiores produções de leite, de leite corrigido para gordura e proteína, e de produções de gordura e proteína do leite, enquanto as vacas que receberam polpa cítrica tiveram maiores teores de gordura e de nitrogênio uréico no leite.

No trabalho de Santos et al. (2001b) foram observadas vantagens na floculação do milho em relação à moagem grosseira. Entretanto, a redução do teor de amido da ração com substituição parcial do milho por polpa cítrica favoreceu o desempenho das vacas devido ao maior teor de gordura do leite e maior produção de leite corrigido para 3,5\% de gordura.

Maior produção de leite corrigido para 3,5\% de gordura também foi relatado por Nussio et al. (2002), quando o teor de amido total da ração foi reduzido através da substituição parcial do milho moído fino ou floculado por polpa cítrica peletizada.

A ingestão de MS, a produção e a composição do leite de vacas confinadas alimentadas com rações contendo silagem de milho não foi afetada pela substituição parcial do milho por polpa cítrica ou raspa de mandioca, de acordo com Scoton (2003). O resultado acima foi semelhante ao observado por Assis et al. (2004a), quando substituíram milho por polpa cítrica, em diversas 
proporções, em rações contendo silagem de sorgo como volumoso, para vacas leiteiras produzindo em média $20 \mathrm{~kg} / \mathrm{d}$.

Estudando os efeitos da substituição parcial ou total do milho por polpa cítrica em rações para vacas em lactação, Moreira et al. (2004) não observaram diferenças na produção de leite corrigido para gordura, no teor de gordura e de lactose do leite. Porém, a inclusão de polpa cítrica nas rações reduziu o teor de proteína e de nitrogênio uréico no leite.

Martinez (2004) não observou diferenças na produção e composição do leite de vacas leiteiras mantidas em pastagens manejadas intensivamente quando substituiu milho por polpa cítrica em diversas proporções.

\subsubsection{Casca de Soja}

A casca de soja é composta principalmente de fibra, que tem pouco valor na alimentação humana e no uso industrial. No entanto, suas características fisico-químicas são alguns dos fatores que fazem da casca de soja um interessante alimento para o gado leiteiro. Considerando-se ainda a facilidade de obtenção da casca de soja em algumas regiões, bem como seu preço competitivo, a sua inclusão em rações para vacas leiteiras pode representar excelente oportunidade de se reduzir custos com alimentação.

A substituição de grãos de cereais por casca de soja em rações para vacas leiteiras pode contribuir para elevar a ingestão de energia, previnir alguma desordem no funcionamento do rúmen, além de ser uma alternativa econômica. A casca de soja pode ser utilizada como uma fonte de fibra em rações onde o volumoso é de má qualidade, ou é fornecido em pequenas quantidades.

Em parte, o valor nutricional da casca de soja para ruminantes é determinado pela natureza química da casca. Como para muitos outros subprodutos, a composição química da casca de soja varia muito entre 
processadores de plantas (Belyea et al., 1989; Arosemena et al., 1995; DePeters et al., 1997).

Outros fatores presumivelmente associados com a variação química da casca de soja incluem: diferenças entre e dentro de métodos de processamento (DePeters et al., 1997), falta de um programa rigoroso de controle de qualidade durante a produção (Belyea et al., 1989), diferenças genéticas entre materiais vegetais e diferenças nas condições culturais e de meio ambiente, durante o crescimento da soja.

Miron et al. (2001) observaram que os carboidratos, predominantemente polímeros de glicose, perfazem aproximadamente $80 \%$ da MS da casca de soja, e muitos destes carboidratos (aproximadamente 75\%) são derivados de polissacarídeos recuperados na fração fibra em detergente neutro (FDN). De acordo com o NRC (2001), a casca de soja contem 60,3\% de FDN e 44,6\% de fibra em detergente ácido (FDA) na MS. A fração fibrosa da casca de soja, que contém relativamente grande quantidade de celulose (aproximadamente 43\% da MS) e hemicelulose (aproximadamente $18 \%$ da MS) é muito pouco lignificada. O teor de lignina da casca de soja está em torno de 1,4\% a 3,9\% quando medido como lignina em detergente ácido e 4,3\% quando medido como lignina em permanganato. Há poucos estudos em que o teor de carboidratos não estruturais ou amido tenham sido medidos.

O valor nutricional da casca de soja é afetado pelas taxas de degradação e de passagem (Firkins, 1997; Grant, 1997). Dados de experimentos in situ e in vitro mostram que os microrganismos ruminais são capazes de fermentar extensivamente a casca de soja. Em recente revisão de Ipharraguerre \& Clark (2003), em cinco de sete estudos, a fração FDN da casca de soja foi fermentada com uma taxa média de $5,6 \% / \mathrm{h}$ e em quatro estudos o desaparecimento de FDN foi em torno de 90\%, após 96 horas de incubação. Embora a fermentação da casca de soja pelos microrganismos ruminais seja relativamente rápida e completa, a digestão in vivo da casca é muito menor do que a fermentação in vitro ou in situ (Hsu et al., 1987; Anderson et al., 1988). 
Essas diferenças são maiores quando a casca de soja é fornecida sozinha ou constituindo o principal ingrediente da ração.

Nakamura \& Owen (1989) determinaram a taxa fracional de passagem da casca de soja em vacas em lactação alimentadas com rações em que a casca de soja substituía o milho, com proporções de casca de $25 \%$ ou de $48 \%$ da MS. Os autores observaram que a taxa de passagem da casca de soja foi $8 \%$ mais rápida quando esta constituía 48\% da MS. Embora as diferenças entre os tratamentos não tenham sido significativas, os autores sugeriram que um aumento de $8 \%$ na taxa de passagem poderia ser responsável pela menor digestibilidade de FDN e FDA observada nessa ração.

Quando a casca de soja foi gradualmente aumentada na ração para substituir $0 \%, 10 \%, 20 \%, 30 \%$ e $40 \%$ da MS suprida como milho, a ingestão de MS diminuiu linearmente, mas o maior decréscimo ocorreu quando a casca foi fornecida em mais de 30\% da MS (Ipharraguerre et al., 2002a). Dados de alguns autores (Batajoo \& Shaver, 1998; Mertens, 1997; Ipharraguerre et al., $2002 a$ b), indicam que a inclusão de casca de soja em teores acima de $30 \%$ da MS diminui a fibra fisicamente efetiva, o que pode elevar a concentração de ácidos no rúmen e diminuir a ingestão pelos animais.

Ipharraguerre \& Clark (2003) fizeram análises de regressão múltipla utilizando dados de estudos selecionados afim de avaliar a relação entre o desempenho de vacas leiteiras e a substituição do milho pela casca de soja. Em 13 de 15 estudos não houve diferença na ingestão de MS, em animais alimentados com dietas controle, comparados aqueles que receberam casca de soja.

A correlação entre produção de leite e o teor de casca de soja na ração, em 10 dos 15 estudos analisados por Ipharraguerre \& Clark (2003), foi baixa e não significativa. Pequenas mudanças na produção de leite têm sido relatadas quando a casca de soja substitui grãos, parcial ou totalmente. O mecanismo pelo qual a casca de soja aumenta a produção de leite, quando substitui o grão, não foi identificado (Conrad \& Hibbs, 1961; Sarwar et al., 1992). 
A completa substituição do milho por casca de soja (48\% da MS), em rações contendo $50 \%$ de volumoso e $50 \%$ de concentrado, diminuiu a produção de leite em 2,5 kg/d, em trabalho de Nakamura \& Owen (1989). Os autores sugerem que o baixo teor de amido da ração que continha casca de soja limitou a produção de leite, mas a menor digestibilidade da MS dessa ração também pode ter contribuído para a redução na produção de leite.

Bernard \& Mcneill (1991) substituíram parcialmente o milho por casca de soja, glúten de milho ou trigo, em rações de vacas produzindo aproximadamente $28 \mathrm{~kg} / \mathrm{d}$ de leite. Não houve efeito da substituição sobre a produção de leite e sobre o teor de gordura do leite. O teor de proteína do leite foi maior para o tratamento com glúten de milho, em comparação ao contendo casca de soja, não havendo diferença entre os tratamentos com casca de soja ou milho.

O efeito de diversos teores de carboidratos não estruturais na ração sobre a produção e a composição do leite de vacas em início de lactação foi avaliado em trabalho de Coomer et al. (1993). Os teores de carboidratos não estruturais foram alterados pela substituição do trigo e do milho por glúten de milho e por casca de soja no concentrado. As produções de leite e de leite corrigido para gordura não foram afetadas pelos tratamentos, mas o teor de gordura e a eficiência alimentar diminuíram, conforme o teor de carboidrato não estrutural na ração aumentou.

Assis et al. (2004b) susbtituíram o milho por casca de soja, em diversas proporções, em rações de vacas leiteiras confinadas produzindo em média 29,5 kg/d de leite. A ingestão de MS, a produção e a composição do leite não foram afetadas pela substituição.

Em 10 dos 15 estudos revisados por Ipharraguerre \& Clark (2003), o teor de gordura do leite não se correlacionou com o teor de casca de soja na ração, nem com o teor de FDN provindo da casca de soja. Dados indicam que o FDN proveniente da casca de soja é efetivo para manter ou levemente aumentar o teor de gordura do leite quando ela é usada para substituir grãos. A falta de 
efeitos consistentes da inclusão de casca de soja na ração sobre a produção de leite e de gordura do leite resultaram em correlação não significativa entre a quantidade de casca de soja utilizada e a produção de leite corrigida para teor de gordura.

Em 2 de 4 estudos onde a casca de soja aumentou o teor de gordura do leite (Nakamura \& Owen, 1989; Pantoja et al., 1994), a produção de leite diminuiu e a produção de leite corrigido para gordura não diferiu.

A substituição de grão de cereais por casca de soja diminuiu significativamente (Firkins \& Eastridge, 1992, Sarwar et al., 1992; Pantoja et al., 1994) ou numericamente (Conrad \& Hibbs, 1961; Ipharraguerre et al., 2002a) o teor de proteína do leite. Essa resposta pode ser parcialmente explicada pelo baixo teor de carboidratos não estruturais em rações que contêm altos teores de casca de soja, que pode limitar a síntese de proteína microbiana no rúmen (Sarwar et al., 1992).

\subsection{Aditivos microbiológicos}

O interesse no uso de microrganismos fornecidos diretamente como suplementos alimentares para vacas de alta produção tem aumentado bastante nos últimos anos. Um desses suplementos comumente utilizados é o que contém Saccharomyces cerevisiae. Entretanto, resultados de pesquisa com essa levedura fornecida para o gado leiteiro têm variado. Aumentos na ingestão de MS (Williams et al., 1991; Wohlt et al., 1991, 1998), produção de leite (Harris \& Wobb, 1990; Williams et al., 1991; Piva et al., 1993; Adams et al., 1995; Putman et al., 1997; Kung et al., 1997; Robinson \& Garret, 1999; Wohlt et al., 1991, 1998) e componentes do leite (Piva et al., 1993) têm sido observados. Em contraste, não foram encontradas diferenças na ingestão de MS (Piva et al., 1993; Robinson, 1997; Robinson \& Garret, 1999), produção de leite (Robinson, 1997; Swartz et al., 1994), ou composição do leite (Robinson, 1997; Robinson \& 
Garret, 1999; Swartz et al., 1994) em outros estudos em que também foi utilizada a levedura como aditivo microbiológico.

Piva et al. (1993) sugeriram que vários fatores podem afetar a resposta de vacas leiteiras à suplementação com levedura, como estágio de lactação, tipo de forragem fornecida, estratégia de alimentação e proporção volumoso:concentrado da ração.

Em revisão sobre o assunto, Yoon \& Stern (1995) observaram aumentos significativos em dois de dez estudos onde foi avaliada a ingestão de MS, e em três de onze estudos onde foi avaliada a produção de leite, utilizando-se o aditivo microbiológico.

Dann et al. (2000) avaliaram o efeito da utilização de aditivo microbiológico sobre a ingestão de MS, sobre a produção e composição do leite em rações de vacas da raça Jersey, primíparas e multíparas, nos últimos 21 dias pré-parto até os primeiros 140 dias pós-parto. O aditivo microbiológico aumentou a ingestão de MS durante os últimos 7 dias de gestação e durante os primeiros 42 dias de lactação. Também resultou em vacas perdendo menos peso e usando menos reserva energética corporal para produção de leite durante o início da lactação. Embora as vacas que receberam aditivo tenham chegado ao pico da lactação mais cedo, não houve aumento na produção total de leite e nem mudanças na composição do leite.

Vacas leiteiras recebendo aditivo microbiológico apresentaram maiores taxas de degradação da MS e da FDN do volumoso, em trabalho de Carro et al. (1992). Entretanto, não houve efeitos sobre a digestibilidade in vivo dos nutrientes, provavelmente pela maior taxa de passagem observada nos animais que receberam aditivo. Os autores comentam que os efeitos da levedura sobre a digestibilidade são mais pronunciados em rações com altos teores de concentrado (aproximadamente 70\%).

Experimentos in vitro têm mostrado que, em alguns casos, a cultura de Saccharomyces cerevisiae altera favoravelmente a fermentação de misturas de microrganismos ruminais e estimula a captura de lactato e a digestão de 
celulose por culturas puras de bactérias predominantemente ruminais (Nisbet \& Martin, 1991; Martin \& Nisbet, 1992; Callaway \& Martin, 1997). Embora os efeitos não sejam consistentes, vários modelos têm proposto efeitos estimulatórios da cultura de levedura sobre a fermentação ruminal (Wallace, 1994). Não sabe-se como e nem porque as culturas de leveduras aumentam o número de bactérias. Um mecanismo provável de proteção das bactérias anaeróbias do rúmen contra danos causados pelo oxigênio é aquele exercido pela atividade respiratória das leveduras (Newbold et al., 1996). 


\title{
3 ADITIVO MICROBIOLÓGICO (Saccharomyces cerevisiae) E SUBSTITUIÇÃO PARCIAL DO MILHO MOÍDO POR POLPA CÍTRICA PELETIZADA EM RAÇÕES PARA VACAS LEITEIRAS EM FINAL DE LACTAÇÃO
}

\author{
Autor: CAROLINA DE ALMEIDA CARMO
} Orientador: Prof. Dr. FLÁVIO AUGUSTO PORTELA SANTOS

\section{Resumo}

O trabalho foi conduzido no Departamento de Zootecnia da Escola Superior de Agricultura "Luiz de Queiroz", Universidade de São Paulo. Para avaliação da suplementação com aditivo microbiológico (Levucell SC20 Lallemand Animal Nutrition) e da substituição parcial (50\%) de milho finamente moído por polpa cítrica peletizada foram utilizadas trinta e seis vacas da raça Holandesa (330 DEL). O delineamento utilizado foi o de Quadrados Latinos 4x4 repetidos. O período experimental foi de 96 dias, com quatro subperíodos de 24 dias, sendo os primeiros 20 dias foram para adaptação dos animais às rações e os quatro dias restantes para coleta de dados. As variáveis avaliadas foram: ingestão de matéria seca, produção e composição do leite e teores de glicose e nitrogênio uréico plasmáticos. A ingestão de matéria seca, produção e composição do leite e a glicose plasmática não foram afetadas $(P>0,05)$ pelos tratamentos. O nitrogênio uréico no leite foi maior $(P<0,05)$ nos animais que foram suplementados com aditivo microbiológico. O nitrogênio uréico no plasma foi reduzido pela substituição parcial do milho pela polpa cítrica $(P<0,05)$. A 
substituição parcial do milho por polpa cítrica não teve efeito negativo sobre o desempenho de vacas produzindo em média $19 \mathrm{~kg} / \mathrm{d}$ de leite.

\section{Yeast culture (Saccharomyces cerevisiae) and replacement of corn grain by dried citrus pulp in late lactating dairy cow rations}

Author: CAROLINA DE ALMEIDA CARMO

Adviser: Prof. Dr. FLÁVIO AUGUSTO PORTELA SANTOS

\section{Summary}

The trial was conducted in the Animal Science Department of the ESALQ, University of São Paulo. Thirty six lactating Holstein cows (330 DIM) were used to study the supplementation of yeast culture (Levucell SC20 - Lallemand Animal Nutrition) in dairy rations and the partial (50\%) replacement of finely ground corn by dried citrus pulp. A repeated 4x4 Latin Square Design was used. The experimental period lasted 96 days with four periods of 24 days, the first 20 days were for adaptation and the last four days were used for collection data. The parameters evaluated were: dry matter intake, milk yield and composition and plasma glucose and urea nitrogen. Dry matter intake, milk yield and composition and plasma glucose were not affected $(P>0,05)$ by treatments. Milk urea nitrogen was raised by yeast culture supplementation $(P<0,05)$. Plasma urea nitrogen was reduced by feeding citrus pulp in partial replacement of corn $(P<0,05)$. The partial replacement of finely ground corn by dried citrus pulp did not affect the cows performance with $19 \mathrm{~kg} / \mathrm{d}$ milk yield.

\subsection{Introdução}

Os grãos de cereais são algumas das principais fontes de energia em rações para vacas leiteiras. Entretanto, nos últimos anos, no Brasil, tem 
crescido o interesse por fontes energéticas alternativas, especialmente quando o preço do milho está elevado. O estado de São Paulo é o maior produtor de citros do Brasil e consequentemente de polpa cítrica peletizada. A produção brasileira anual estimada é de 1.150 .000 toneladas (Santos et al., 2004a). Esta alta disponibilidade tem tornado este subproduto uma fonte energética concentrada mais competitiva que o milho, nos últimos anos.

Em rações para animais de alta produção, onde o teor de alimentos concentrados é elevado, o ambiente ruminal pode ser prejudicado com efeitos deletérios na manutenção da motilidade ruminal e estímulo à ruminação, devido a deficiência de fibra na ração. A substituição de parte do milho por polpa cítrica peletizada permite elevar o nível de fibra na ração e ainda manter adequada a disponibilidade de carboidrato degradável no rúmen, de acordo com Giardini (1993). Apesar do médio teor de FDA (por volta de 24\%), a polpa cítrica tem baixo teor de lignina (1\%), sendo quase toda a fibra digerida no rúmen, uma vez que a celulose representa aproximadamente $23 \%$ da matéria seca da polpa e é altamente digerida pelos microrganismos ruminais (Orskov, 1987).

Um ponto a ser questionado é o valor energético inferior da polpa cítrica em relação ao milho, sugerido pelo NRC (2001). Os dados com silagem de milho (Santos et al., 2001b; Nussio et al., 2002) e com pastagem tropical manejada intensivamente durante o verão (Martinez, 2004) sugerem valor energético igual ou superior da polpa em relação ao milho, quando a polpa substitui parcialmente este cereal na ração.

O interesse pelo uso de microrganismos fornecidos diretamente como suplementos alimentares para vacas leiteiras tem aumentado bastante nos últimos anos. Um desses suplementos é o que contém Saccharomyces cerevisiae. Estabilização do pH ruminal, maior digestão de frações fibrosas dos alimentos, maior consumo e aumento na síntese microbiana têm sido apontados como prováveis responsáveis pelo melhora no desempenho animal observado em diversos estudos. Tem sido sugerido que vacas sob estresse 
térmico e recebendo rações com alto teor de amido teriam maiores chances de responder a este tipo de aditivo (Arambel \& Kent,1990).

Experimentos in vitro mostraram que, em alguns casos, a cultura de Saccharomyces cerevisiae altera favoravelmente a fermentação de misturas de microorganismos ruminais e estimula a captura de lactato e a digestão de celulose por culturas puras de bactérias predominantemente ruminais (Nisbet \& Martin, 1991; Martin \& Nisbet, 1992; Callaway \& Martin, 1997). Efeitos estimulatórios da cultura de levedura sobre a fermentação ruminal, embora não consistentes, têm sido discutidos (Wallace, 1994). Não se sabe como e nem por que as culturas de leveduras aumentam o número de bactérias, mas um mecanismo proposto é que a atividade respiratória das leveduras protege as bactérias anaeróbias do rúmen contra danos pelo oxigênio (Newbold et al., 1996).

Os trabalhos de desempenho, entretanto, têm mostrado resultados variáveis com o uso de levedura para vacas leiteiras. Aumentos na ingestão de matéria seca (Williams et al., 1991; Wohlt et al., 1991, 1998), produção de leite (Harris \& Wobb, 1990; Williams et al., 1991; Piva et al., 1993; Adams et al., 1995; Putman et al., 1997; Kung et al., 1997; Robinson \& Garret, 1999; Wohlt et al., 1991, 1998) e componentes do leite (Piva et al., 1993) têm sido observados quando vacas leiteiras são alimentadas com levedura. Em contraste, não foram encontradas diferenças na ingestão de matéria seca (Piva et al., 1993; Robinson, 1997; Robinson \& Garret, 1999), produção de leite (Robinson, 1997; Swartz et al., 1994), ou composição do leite (Robinson, 1997; Robinson \& Garret, 1999; Swartz et al., 1994) em outros estudos em que também foi utilizada a levedura.

Vários fatores podem afetar a resposta de vacas leiteiras à suplementação com aditivo microbiológico, como estágio de lactação, tipo de forragem fornecida, estratégia de alimentação e proporção volumoso:concentrado da ração (Piva et al.,1993). 
O presente trabalho objetiva contribuir com informações dentro desse contexto, avaliando o desempenho de vacas em lactação que recebem rações com aditivo microbiológico (Saccharomyces cerevisiae) e com a substituição parcial do milho por polpa cítrica peletizada.

\subsection{Material e Métodos}

\subsubsection{Local e Animais}

O experimento foi conduzido nas instalações do Departamento de Zootecnia da Escola Superior de Agricultura "Luiz de Queiroz", Universidade de São Paulo, entre os meses de janeiro a abril de 2002.

As instalações constaram de um sistema de confinamento do tipo "freestall" com quatro lotes, contendo 12 baias por lote.

Foram utilizadas 36 vacas da raça Holandesa com período médio de lactação de 330 dias $( \pm 185)$ e produção média de leite de 18 kg/d. Esses valores foram tomados como média no meio do experimento.

\subsubsection{Tratamentos}

O trabalho experimental foi delineado para estudar a inclusão de um aditivo microbiológico contendo Saccharomyces cerevisiae em rações com ou sem substituição parcial do milho moído fino (tamanho médio de partícula de $1,2 \mathrm{~mm}$ ) por polpa cítrica peletizada (50\% da MS). O aditivo utilizado foi Levucell SC20 da Empresa Lallemand Animal Nutrition, na dose de $1 \times 10^{10}$ ufc/animal/dia, o que equivale a 0,5 g/dia. Foi feita uma pré mistura do aditivo microbiológico em farelo de soja e tomou-se uma quantidade fixa desta pré mistura que foi adicionada à ração, de maneira a garantir o fornecimento de 0,5g/animal/dia de aditivo. 
As rações foram formuladas através do programa NRC (2001) para suprirem quantidades adequadas de proteína degradável no rúmen e proteína metabolizável. Os ingredientes utilizados foram: silagem de milho, milho moído fino, polpa cítrica peletizada, farelo de soja, suplemento mineral e vitamínico e bicarbonato de sódio (Tabela 1 ).

Tabela 1. Composição das dietas experimentais

\begin{tabular}{lcccc}
\hline & M50 $^{1}$ & M50L & M100 & M100L \\
& \multicolumn{4}{c}{$\%$ da MS } \\
\hline Silagem de milho & 49,60 & 49,60 & 49,60 & 49,60 \\
Milho moído fino & 12,28 & 12,28 & 25,32 & 25,32 \\
Polpa cítrica peletizada & 12,28 & 12,28 & --- & ---- \\
Farelo de soja $^{2}$ & 22,32 & 22,32 & 21,57 & 21,57 \\
Supl. Min. Vit. $^{2}$ & 2,81 & 2,81 & 2,81 & 2,81 \\
Bicarbonato de Na & 0,70 & 0,70 & 0,70 & 0,70
\end{tabular}

${ }^{1} \mathrm{M} 50=$ proporção milho:polpa de 50:50, sem levedura; M50L= proporção milho:polpa de 50:50, com levedura; M100= proporção milho:polpa de 100:0, sem levedura; M100L= proporção milho:polpa de 100:0, com levedura.

${ }^{2}$ Supl. Min. Vit. = Suplemento Mineral e Vitamínico, contendo por kg de suplemento: $55,0 \mathrm{~g}$ de Fósforo ; 220,0 g de Cálcio, 105,5 g de Cloro; 70,0 g de Sódio; 35,0 $\mathrm{g}$ de Magnésio; 22,0 $\mathrm{g}$ de Enxofre; 1500,0 mg de Manganês; 500,0 mg de Ferro; 1550,0 mg de Zinco; 450,0 mg de Cobre; 50,0 mg de Cobalto; 40,0 mg de lodo; 20,0 mg de Selênio; 550,0 mg de Flúor; 90000 UI de Vitamina $A ; 75000$ UI de Vitamina $D_{3}$ e 1000 UI de Vitamina $E$.

\subsubsection{Período experimental e coleta de dados}

O período experimental teve a duração de 96 dias divididos em quatro subperíodos de 24 dias. Os 20 primeiros dias de cada subperíodo foram para adaptação dos animais às rações e os outros quatro dias para coleta de dados. Esse período de adaptação de 20 dias foi recomendado pela empresa Lallemand Animal Nutrition. 
Os animais foram pesados no início e no final do experimento, e a condição corporal foi avaliada no início de cada subperíodo experimental, utilizando-se a escala de 1 a 5 de acordo com Wildman et al. (1982).

Os animais foram ordenhados às 6:00 e às 18:00, e as produções de leite individuais foram registradas nos quatro dias de coleta de dados, através de medidores do tipo "Mark V". Amostras de leite de cada vaca foram coletadas também nesses dias, nas ordenhas da manhã e da tarde, sendo compostas por dia e analisadas para gordura, proteína, lactose e sólidos totais, pelo processo de infravermelho através do analisador Bentley 2000 (Bentley Instruments); e nitrogênio uréico pelo analisador ChemSpec 150 (Bentley Instruments) no Laboratório da Clínica do Leite do Departamento de Zootecnia da Escola Superior de Agricultura "Luiz de Queiroz", Universidade de São Paulo.

As rações foram distribuídas às 6:00 e às 18:00, sendo as sobras de alimento mensuradas e descartadas diariamente antes do fornecimento do período da tarde. O consumo de alimento foi medido em grupo, por tratamento diariamente, durante os quatro dias de coleta de dados.

Amostras das rações e das sobras foram retiradas nos quatro dias de coleta de dados. A silagem foi amostrada semanalmente, e os outros alimentos, no início de cada período de coleta de dados, sendo as amostras de silagem armazenadas $\mathrm{a}-18^{\circ} \mathrm{C}$. Subamostras da silagem foram secadas imediatamente após a amostragem, a $105^{\circ} \mathrm{C}$ por 24 horas para determinação da MS, a fim de ajustar a quantidade de silagem a ser fornecida.

Após o período experimental, as amostras de alimentos e rações foram secadas a $55^{\circ} \mathrm{C}$ (em estufa com circulação forçada de ar por 72 horas) e analisadas para MS (três horas em estufa a $105^{\circ} \mathrm{C}$ ), para matéria orgânica (MO) (três horas em mufla a $600^{\circ} \mathrm{C}$ ), para FDN e FDA através do digestor Ankom, de acordo com Van Soest et al. (1991), para proteína bruta (PB) através de condução térmica no equipamento Leco FP 528 (Leco Corporation, St. Joseph MI), e, para amido, segundo método descrito por Poore et al. (1993a). Foi determinada apenas a MS das amostras de sobras para cálculo da ingestão de 
matéria seca pelos animais. As análises foram realizadas no Laboratório de Bromatologia do Departamento de Zootecnia da Escola Superior de Agricultura "Luiz de Queiroz", Universidade de São Paulo.

As amostras de sangue foram coletadas em tubos com fluoreto de sódio como antiglicolítico, e oxalato de potássio como anticoagulante, no último dia de coleta de dados, quatro horas após alimentação. As amostras foram centrifugadas em 3000 x g por 20 minutos, armazenadas em tubos de $2 \mathrm{~mL}$ tipo "eppendorf" a $-10^{\circ} \mathrm{C}$, e posteriormente analisadas para glicose através do Analisador Bioquímico YSI 2700S (Yellow Springs Instrument Co. Inc., Ohio, USA), e, para uréia, através do Kit Analisa (Analisa Indústria e Comércio Ltda.), método colorimétrico. As análises de glicose foram realizadas no Laboratório de Bromatologia do Departamento de Zootecnia da Escola Superior de Agricultura "Luiz de Queiroz", Universidade de São Paulo e as análises de uréia no Biomed Laboratórios de Análises Clínicas. O valor obtido de uréia foi convertido para nitrogênio uréico, considerando-se $46,6 \%$ de nitrogênio na uréia.

\subsubsection{Delineamento experimental e análise estatística}

O delineamento experimental utilizado foi o de Quadrados Latinos $4 \times 4$ repetidos, em arranjo fatorial (dois níveis de substituição do milho, 0 e 50\%, e duas doses de aditivo microbiológico, 0 e 0,5 g/an/d). Foram utilizados trinta e seis animais distribuídos em nove Quadrados Latinos.

Os dados de consumo foram analisados como um Quadrado Latino simples, onde cada grupo de animais, de cada tratamento, foi considerado a unidade experimental, em virtude do consumo de alimento ter sido medido em grupo e não individualmente.

Os dados foram analisados pelo PROC GLM (General Linear Models) do programa estatístico SAS (1999), versão 8 para Windows. Foi feito o teste de comparação de médias dos Quadrados Mínimos. Considerou-se o nível de significância de $5 \%$, e até $10 \%$ como tendência de significância para a 
probabilidade do teste $F$ na análise de variância e no teste de comparação de médias.

\subsection{Resultados e Discussão}

Os dados da análise bromatológica dos ingredientes são apresentados na Tabela 2. Pode-se observar que o teor de MS da silagem de milho está abaixo da faixa recomendada (entre 32 a 35\%), sugerindo que o material foi ensilado antes do ponto ideal de colheita, conforme Nussio (1991). O teor de FDA da polpa cítrica está seis pontos percentuais abaixo do valor da tabela do NRC (2001). Os teores de FDN do farelo de soja e de amido da polpa cítrica estão bem acima dos valores de tabela do NRC (2001). A composição das rações foi estimada a partir dos resultados dos ingredientes. Nesses cálculos o teor de amido da polpa cítrica foi considerado como 0,5\%, por estar mais próximo aos valores encontrados na literatura (Wainman \& Dewey, 1988; Mertens, 1992, citado por Carvalho, 1995). 
Tabela 2. Composição bromatológica dos ingredientes e rações

\begin{tabular}{lcccccc}
\hline & & & \multicolumn{3}{c}{$\%$ da MS } \\
& MS (\%) & MO & PB & FDN & FDA & Amido \\
\hline Silagem de milho & 26,92 & 95,68 & 7,83 & 46,79 & 27,00 & 22,74 \\
Milho moído fino & 88,66 & 98,84 & 8,96 & 9,30 & 2,28 & 74,10 \\
Polpa cítrica peletizada & 89,26 & 93,39 & 6,69 & 23,89 & 16,30 & * \\
Farelo de soja & 89,67 & 93,97 & 48,09 & 19,34 & 7,86 & 10,51 \\
Rações & & & & & & \\
M501 & 44,99 & 93,04 & 17,65 & 29,55 & 16,15 & 22,70 \\
M50L & 44,99 & 93,04 & 17,65 & 29,55 & 16,15 & 22,70 \\
M100 & 44,87 & 93,84 & 17,69 & 27,46 & 14,15 & 33,60 \\
M100L & 44,87 & 93,84 & 17,69 & 27,46 & 14,15 & 33,60 \\
\hline
\end{tabular}

${ }^{1} \mathrm{M} 50=$ proporção milho:polpa de 50:50, sem levedura; M50L= proporção milho:polpa de 50:50, com levedura; $\mathrm{M} 100=$ proporção milho:polpa de 100:0, sem levedura; M100L= proporção milho:polpa de 100:0, com levedura. ${ }^{*}$ considerado valor de tabela de $0,5 \%$.

Os pesos vivos e escores de condição corporal médios de todos os animais, no início e no final do período experimental, foram $610 \mathrm{~kg}, 640 \mathrm{~kg}, 3,2$ e 3,3, respectivamente. Na Tabela 3 são apresentados os dados de ingestão de MS, eficiência alimentar, produção e composição do leite, nitrogênio uréico e glicose plasmáticos e variação do escore da condição corporal. 
Tabela 3. Ingestão de matéria seca, eficiência alimentar, produção e composição do leite, nitrogênio uréico e glicose plasmáticos e variação do escore de condição corporal

\begin{tabular}{|c|c|c|c|c|c|c|c|c|}
\hline & \multicolumn{4}{|c|}{ Tratamentos } & \multicolumn{4}{|c|}{$P<$} \\
\hline & $\mathrm{M} 50^{1}$ & M50L & M100 & M100L & $\mathrm{EPM}^{2}$ & $T^{3}$ & A & TXA \\
\hline $\mathrm{IMS}^{4}(\mathrm{~kg} / \mathrm{an} / \mathrm{d})$ & 18,86 & 18,57 & 18,13 & 18,77 & 0,34 & 0,46 & 0,60 & 0,20 \\
\hline Leite (kg/an/d) & 18,89 & 19,29 & 19,28 & 18,72 & 0,37 & 0,80 & 0,82 & 0,20 \\
\hline LCG $3,5^{5}(\mathrm{~kg} / \mathrm{an} / \mathrm{d})$ & 19,39 & 19,45 & 20,10 & 18,83 & 0,53 & 0,93 & 0,25 & 0,22 \\
\hline Eficiência (LCG 3,5/IMS) & 1,05 & 1,07 & 1,11 & 1,05 & 0,05 & 0,70 & 0,77 & 0,53 \\
\hline \multicolumn{9}{|l|}{ Composição do leite } \\
\hline Gordura (\%) & 3,74 & 3,64 & 3,74 & 3,61 & 0,14 & 0,95 & 0,41 & 0,92 \\
\hline Gordura (kg/an/d) & 0,69 & 0,68 & 0,72 & 0,66 & 0,03 & 0,85 & 0,23 & 0,32 \\
\hline Proteína (\%) & 3,53 & 3,49 & 3,50 & 3,62 & 0,09 & 0,58 & 0,64 & 0,36 \\
\hline Proteína (kg/an/d) & 0,65 & 0,66 & 0,67 & 0,67 & 0,02 & 0,52 & 0,90 & 0,74 \\
\hline Lactose (\%) & 4,01 & 4,08 & 3,97 & 4,06 & 0,08 & 0,70 & 0,30 & 0,92 \\
\hline Lactose $(\mathrm{kg} / \mathrm{an} / \mathrm{d})$ & 0,76 & 0,79 & 0,77 & 0,76 & 0,02 & 0,59 & 0,56 & 0,46 \\
\hline Sólidos totais (\%) & 12,21 & 12,15 & 12,12 & 12,24 & 0,26 & 0,98 & 0,92 & 0,72 \\
\hline Sólidos totais (kg/an/d) & 2,28 & 2,32 & 2,35 & 2,27 & 0,06 & 0,90 & 0,78 & 0,38 \\
\hline $\mathrm{NUL}^{6}(\mathrm{mg} / \mathrm{dL})$ & 16,39 & 15,41 & 16,66 & 15,16 & 0,59 & 0,98 & 0,03 & 0,66 \\
\hline $\mathrm{NUP}^{7}$ (mg/dL) & $19,39^{b}$ & $18,90^{\mathrm{b}}$ & $20,85^{a}$ & $21,38^{\mathrm{a}}$ & 0,49 & $<0,01$ & 0,97 & 0,30 \\
\hline Glicose (mg/dL) & 60,62 & 60,12 & 62,22 & 62,23 & 1,49 & 0,21 & 0,87 & 0,86 \\
\hline Variação do ECC ${ }^{8}$ & $0,10^{\mathrm{a}}$ & $-0,02^{b}$ & $0,02^{a b}$ & $0,10^{\mathrm{a}}$ & 0,05 & 0,66 & 0,71 & 0,05 \\
\hline
\end{tabular}

${ }^{1} \mathrm{M} 50=$ proporção milho:polpa de 50:50, sem aditivo; M50L= proporção milho:polpa de 50:50, com aditivo; $M 100=$ proporção milho: polpa de 100:0, sem aditivo; $\mathrm{M} 100 \mathrm{~L}=$ proporção milho:polpa de 100:0, com aditivo.

${ }^{2} \mathrm{EPM}=$ erro padrão da média.

${ }^{3} \mathrm{~T}=$ efeito do teor de amido; $\mathrm{A}=$ efeito do aditivo; $\mathrm{TXA}=$ interação teor de amido e inclusão de aditivo.

${ }^{4} \mathrm{IMS}=$ ingestão de matéria seca.

${ }^{5}$ LCG 3,5= leite corrigido para teor de gordura igual a 3,5\%.

${ }^{6} \mathrm{NUL}=$ nitrogênio uréico no leite.

${ }^{7} \mathrm{NUP}=$ nitrogênio uréico no plasma.

${ }^{8} \mathrm{ECC}=$ escore da condição corporal.

Letras diferentes nas linhas referem-se a médias que diferem entre si pelo Teste dos Quadrados Mínimos $(P<0,05)$. 


\subsubsection{Ingestão de matéria seca}

A substituição parcial do milho por polpa cítrica não afetou a ingestão de MS ( $P>0,05)$. Santos et al. (2001b), Nussio et al. (2002) e Scoton (2003) também não observaram efeito da substituição parcial do milho por polpa cítrica sobre a ingestão de MS de vacas no terço médio e final de lactação.

Essa substituição permite elevar o teor de fibra na ração e ainda manter adequada a disponibilidade de carboidrato degradável no rúmen. A fração fibrosa da polpa cítrica apresenta elevada digestibilidade ruminal, pois tem baixo teor de lignina (1\% na MS), não sendo seu teor fibroso fator limitante à ingestão de MS.

A polpa cítrica apresenta em sua composição grande quantidade de pectina, que é de 90 a 100\% degradável no rúmen (Nocek \& Tamminga, 1991; Stern \& Ziemer, 1993), e o carboidrato complexo de mais rápida degradação ruminal (Van Soest, 1994). Sniffen (1988) observou taxas de degradação ruminal entre $30 \%$ e $50 \%$ por hora para a pectina. Chesson \& Monro (1982) encontraram valores similares de $30 \%$ a $45 \%$ por hora de taxa de degradação para a pectina, tendo sua quase completa degradação em 12 ou 18 horas.

A redução na queda do $\mathrm{pH}$ ruminal, devido à fermentação acética em substituição à fermentação lática e à capacidade de tamponamento ruminal da pectina, podem resultar em ambiente ruminal mais adequado para a atividade microbiana e estimular a ingestão de MS, conforme Van Soest (1987). Entretanto, no presente experimento, a ingestão de MS não foi alterada pela inclusão de polpa cítrica.

A suplementação com aditivo microbiológico não afetou $(P>0,05)$ a ingestão de MS de vacas no terço final de lactação. Esses dados estão de acordo com os resultados de Piva et al. (1993), Swartz et al. (1994), Robinson (1997), Robinson \& Garret (1999) e de Yoon \& Stern (1995), que observaram aumentos significativos na ingestão de MS em apenas dois de dez estudos revisados. 
Entretanto, os resultados de pesquisas com utilização de aditivos microbiológicos para vacas em lactação têm sido muito variáveis, onde aumentos na ingestão de MS foram observados por alguns autores (Williams et al., 1991; Wohlt et al., 1991; 1998).

Em trabalho de Dann et al. (2000) o fornecimento de aditivo microbiológico aumentou a ingestão de MS durante os últimos 7 dias de gestação e durante os primeiros 42 dias de lactação. Talvez a suplementação com este aditivo possa ser mais eficaz no período de transição e início da lactação, quando o animal encontra-se em estresse mais intenso, diferentemente da condição do presente trabalho, no qual as vacas estavam no terço final da lactação.

Arambel \& Kent (1990) também sugeriram que aditivos microbiológicos podem ser melhor utilizados por animais sob estresse. Uma possível explicação deste efeito seria que a baixa ingestão de MS não proporcionaria fatores de crescimento suficientes à população bacteriana, como ácidos orgânicos, vitamina B e aminoácidos. Callaway \& Martin (1997) sugeriram que a cultura de levedura proporciona esses fatores estimulantes do crescimento de bactérias celulolíticas e à digestão de celulose.

No presente estudo, apesar das elevadas temperaturas diurnas e alta umidade relativa do ar e também considerando-se o estágio de lactação em que os animais se encontravam, é possível que as condições de estresse e exigência nutricional não tenham sido tão críticas a ponto de propiciarem respostas positivas da utilização de aditivo microbiológico sobre a ingestão de MS.

\subsubsection{Produção de leite}

De acordo com a equação de Weiss utilizada pelo NRC (2001), a polpa cítrica tem valor energético inferior ao milho moído fino $(80,38 \%$ versus $88,68 \%$ de nutrientes digestíveis totais - NDT), e, em qualquer simulação utilizando-se o 
programa, a substituição parcial do milho por polpa cítrica resulta em menor produção de leite.

Entretanto, neste estudo as produções de leite e de LCG 3,5 não foram afetadas pela substituição parcial do milho por polpa cítrica $(P>0,05)$. A maioria dos trabalhos publicados não mostrou diferenças na produção de leite quando a polpa cítrica substituiu parcialmente o milho na ração. A ausência deste efeito negativo da polpa em diversos trabalhos (Van Horn et al., 1975; Lucci et al., 1975; Belibasakis \& Tsirgogianni, 1996; Santos et al., 2001b; Nussio et al., 2002; Scoton, 2003 e Moreira et al., 2004), pode ser explicada com base em algumas hipóteses. Uma delas é pelo melhor ambiente ruminal proporcionado pela polpa cítrica, que pode favorecer a digestibilidade de nutrientes; a outra seria devido à maior digestibilidade ruminal dos carboidratos não fibrosos da polpa cítrica em comparação com carboidratos do milho. Esses dados sugerem que a equação de Weiss, utilizada pelo NRC (2001), subestima o valor energético da polpa cítrica em relação ao milho para vacas produzindo entre 15 a $28 \mathrm{~kg} / \mathrm{d}$ de leite.

Tem-se observado um consistente aumento nas produções de LCG 3,5 com a inclusão de polpa cítrica peletizada na ração (Van Horn et al., 1975; Lucci et al., 1975; Belibasakis \& Tsirgogianni, 1996; Santos et al., 2001b e Nussio et al., 2002). Nesses trabalhos, um provável efeito benéfico da polpa no aumento da digestibilidade das frações fibrosas da ração e na menor produção de ácidos graxos trans são algumas das possíveis explicações para o aumento no teor de gordura do leite e, assim, para o aumento da produção de LCG 3,5.

A produção de leite não foi afetada pela suplementação com aditivo microbiológico $(P>0,05)$. Os efeitos da utilização de aditivo microbiológico na produção de leite têm sido inconsistentes, conforme mostra a literatura revisada. Nos trabalhos de Arambel \& Kent (1990), Higginbotham et al. (1994), Swartz et al. (1994), Robinson (1997), Soder \& Holden (1999) e Dann et al. (2000) não houve efeito positivo, ao passo que nos trabalhos de Harris \& Wobb (1990), Williams et al. (1991), Piva et al. (1993), Adams et al. (1995), Putman et 
al. (1997), Kung et al. (1997), Robinson \& Garret (1999), Wohlt et al. (1991, 1998) e Suñé \& Mülbach (1998) a produção de leite foi maior com a utilização do aditivo. Yoon \& Stern (1995) observaram aumentos significativos na produção de leite em apenas três de dez estudos revisados.

Williams et al. (1991) comentaram que a composição da ração pode ter efeito sobre a resposta à utilização de aditivos microbiológicos. Em seu trabalho, a resposta foi melhor em vacas alimentadas com altos teores de carboidratos rapidamente fermentáveis. Os autores propuseram que as respostas com aditivos microbiológicos poderiam ser mais evidentes quando a composição da ração ou o sistema de alimentação pudessem comprometer a digestão de celulose. Neste caso, a ação do aditivo poderia estar parcialmente ligada à diminuição de efeitos associativos negativos que influenciam a digestão de celulose.

Dawson (1993), citado por Higginbotham et al. (1994), constatou que a utilização de aditivos microbiológicos não tem os mesmos efeitos com todos os tipos de rações e que nem sempre é possível definir as condições dietéticas que vão possibilitar respostas ótimas à suplementação.

Vale salientar que, de acordo com os trabalhos revisados, os resultados positivos, quando obtidos, são geralmente inferiores a 10\% de aumento em leite. Respostas da ordem de 3\% a 5\% em produção de leite, para que sejam detectadas estatisticamente, normalmente exigem um número considerável de vacas por tratamento, nem sempre possível nas estações experimentais. Diversos trabalhos onde não se observou resposta significativa estatisticamente, apresentaram resposta numérica. Portanto, nesse tipo de experimento, o número de unidades experimentais precisa ser avaliado cuidadosamente.

As situações dos trabalhos em que foi constatado efeito positivo do aditivo microbiológico são as mais diversas possíveis. São variados tipos de rações, sistemas de alimentação, estágio de lactação, nível de produção das vacas e quantidade de aditivo fornecido, sendo difícil uma padronização para 
melhor comparação. Também não foram encontrados trabalhos com condições iguais as do presente estudo.

\subsubsection{Eficiência alimentar}

Diferentemente do ocorrido nos trabalhos de Santos et al. (2001b) e Andrade (2002), onde a inclusão de polpa cítrica na ração aumentou a eficiência alimentar devido ao aumento no teor de gordura do leite, e conseqüente aumento na produção de leite corrigido para gordura, no presente trabalho não houve efeito dos tratamentos sobre a eficiência alimentar $(P>0,05)$.

\subsubsection{Composição do leite}

Não houve efeito da substituição parcial do milho por polpa cítrica $(P>0,05)$ sobre o teor e produção de gordura do leite. Os dados deste experimento discordam de resultados encontrados na literatura, onde foi observado aumento nos teores e produções de gordura do leite com a inclusão de polpa cítrica peletizada na ração (Drude et al., 1971; Van Horn et al., 1975; Lucci et al., 1975; Belibasakis \& Tsirgogianni, 1996; Leiva et al., 2000; Rojas et al., 2001; Santos et al., 2001b e Nussio et al., 2002).

Por outro lado, Bargo et al. (2003) em recente revisão, Scoton (2003), Assis et al. (2004a), Martinez (2004) e Moreira et al. (2004), também não observaram efeito positivo no teor de gordura do leite, quando incluíram polpa cítrica na ração.

Nos trabalhos onde o teor de gordura do leite estavam inferiores a 3,5\%, a substituição parcial ou total do milho por polpa cítrica pareceu ter maior chance de aumentar o teor de gordura do leite, comparada a situações onde os teores já se encontram adequados (Drude et al., 1971; Leiva et al., 2000; Rojas et al., 2001 e Santos et al., 2001b). 
Apesar de não ter ocorrido efeito sobre o teor de gordura do leite pela substituição parcial do milho por polpa cítrica na ração, esta pode tornar o ambiente ruminal mais favorável (Van Soest, 1991), minimizando a produção de ácidos graxos de cadeia trans que apresentam efeito inibitório sobre a síntese de ácidos graxos de cadeia curta pela glândula mamária (NRC, 2001). A produção destes ácidos graxos ocorre mais intensamente quando o $\mathrm{pH}$ ruminal é baixo, dificultando a biohidrogenação. Os ácidos graxos de cadeia trans atuam diminuindo a atividade de várias enzimas que participam da formação de triglicerídeos no tecido da glândula mamária (estearil CoA desaturase, acetil CoA carboxilase e acil transferases) (Gaynor et al., 1994).

Segundo Oba \& Allen (2003), apesar de em diversos casos a média diária de $\mathrm{pH}$ ruminal não ser diferente, rações com maior teor de amido resultam em maior variação diária do pH ruminal, comparadas às rações com menor teor de amido. Estes autores propuseram que a partição dos nutrientes absorvidos para produção de leite ou reservas corporais é influenciada pela variação no pH ruminal, porque este determina o padrão de suprimento de combustíveis metabólicos do rúmen para a circulação sangüínea (Oba \& Allen, 2000). A taxa de absorção de ácidos pela parede do rúmen é reduzida com a queda do $\mathrm{pH}$. $\mathrm{O} \mathrm{pH}$ ruminal com menor flutuação diária pode resultar em suprimento mais consistente de combustíveis metabólicos do rúmen para a circulação sangüínea, enquanto maior flutuação no pH ruminal pode indicar um suprimento de energia mais variável. Esse suprimento variável de energia pode estimular a secreção de insulina que aumenta a utilização de energia no tecido adiposo, de forma mais intensa do que para a síntese de gordura do leite (Oba \& Allen, 2000).

No trabalho de Oba \& Allen (2003), a redução nos teores de gordura do leite sem o aumento do fluxo de ácidos graxos trans para o intestino, nas rações com maior teor de amido, reforça a hipótese, proposta pelos mesmos autores, dos efeitos da flutuação do pH ruminal sobre a gordura do leite. 
Provavelmente, a síntese de gordura na glândula mamária é controlada por mais de um mecanismo.

A suplementação com aditivo microbiológico não afetou o teor e a produção de gordura do leite $(P>0,05)$, semelhantemente ao observado por Wohlt et al. (1991), Swartz et al. (1994), Robinson (1997), Robinson \& Garret (1999) e Soder \& Holden (1999).

Suñé \& Malbach (1998) observaram teor de gordura do leite mais baixo quando suplementaram vacas em pastejo com aditivo microbiológico e em início de lactação. A produção de gordura foi maior para os animais suplementados devido à maior produção de leite obtida no tratamento com o aditivo, o que também ocorreu no trabalho de Piva et al. (1993).

Arambel \& Kent (1990) comentaram que a ausência de resposta da suplementação com aditivo microbiológico sobre a gordura do leite pode ser um indicativo de que o estímulo aos microrganismos ruminais digestores de fibra não foi suficiente para afetar a produção e composição do leite. Uma outra consideração feita pelos autores foi que o teor de fibra da ração provavelmente estava adequado para manter a síntese de gordura do leite.

Não houve efeito da substituição do milho por polpa cítrica sobre o teor e produção de proteína do leite $(P>0,05)$. Scoton (2003) e Assis et al. (2004a) também não observaram efeito da inclusão de polpa cítrica sobre o teor e a produção de proteína do leite. Santos et al. (2001b) e Moreira et al. (2004) observaram redução nos teores de proteína do leite com a substituição do milho por polpa cítrica. Entretanto, no trabalho de Santos et al. (2001b), a combinação de fontes de amido de alta degradabilidade (milho floculado) com polpa cítrica manteve teores de proteína do leite semelhantes aos obtidos com milho moído grosso.

A redução no teor de proteína do leite devido à redução no teor de amido da ração observada em alguns trabalhos (Santos et al., 2001b, Moreira et al., 2004) poderia ser explicada por menor síntese de proteína microbiana e menor 
produção de propionato no rúmen. Isso poderia restringir a disponibilidade de aminoácidos para a síntese de proteína na glândula mamária.

Em três dos seis trabalhos revisados por Bargo et al. (2003) houve redução no teor de proteína do leite quando fontes de amido foram substituídas por subprodutos, como a polpa cítrica, no concentrado de vacas mantidas em pastagens temperadas. Martinez (2004) não observou efeito da substituição de milho por polpa no teor e produção de proteína do leite de vacas mantidas em pastagem tropical manejada intensivamente.

A suplementação com aditivo microbiológico não afetou o teor e a produção de proteína do leite $(P>0,05)$. Vários autores também não observaram efeito da suplementação com aditivo microbiológico sobre a proteína do leite (Piva et al., 1993; Higginbotham et al., 1994; Swartz et al., 1994; Robinson, 1997; Wohlt et al., 1998; Robinson \& Garret, 1999; Soder \& Holden, 1999; Dann et al., 2000).

No trabalho de Williams et al. (1991), a produção de proteína do leite foi maior quando as vacas foram alimentadas com rações contendo alto teor de concentrado e suplementadas com aditivo microbiológico. Já Suñé \& Malbach (1998) observaram teor de proteína do leite mais baixo quando forneceram aditivo microbiológico para animais em pastejo, em início de lactação.

Os teores e produções de lactose e sólidos totais também não foram afetados pelos tratamentos $(P>0,05)$. Scoton (2003) e Moreira et al. (2004) também não obtiveram diferença no teor de lactose do leite quando substituíram milho por polpa cítrica na ração de vacas leiteiras.

Nos trabalhos de Robinson (1997), Robinson \& Garret (1999) e Soder \& Holden (1999), a suplementação com aditivo microbiológico também não afetou o teor e a produção de lactose do leite. Higginbotham et al. (1994) observaram teores de lactose menores para vacas suplementadas com levedura, comparados aos de vacas que não foram suplementadas. Já Dann et al. (2000) não obtiveram efeito do aditivo microbiológico sobre a lactose e sólidos totais. 
No trabalho de Williams et al. (1991), a suplementação com aditivo microbiológico não teve efeito sobre os sólidos totais do leite.

O teor de nitrogênio uréico no leite não foi afetado pela substituição parcial do milho por polpa cítrica $(P>0,05)$, diferentemente do observado em trabalho de Moreira et al. (2004), onde o teor de nitrogênio uréico no leite foi diminuído pela substituição do milho pela polpa cítrica.

Os dados de teores de nitrogênio uréico no leite e no plasma não tiveram o mesmo padrão de resposta. Isso não era esperado, uma vez que, geralmente, esses dados estão correlacionados positivamente.

A suplementação com levedura reduziu o teor de nitrogênio uréico no leite $(P<0,05)$. Redução no teor de nitrogênio uréico no leite pode ser indicativo de utilização mais eficiente do nitrogênio no rúmen ou nos tecidos periféricos. Soder \& Holden (1999) e Dann et al. (2000) não observaram efeito da suplementação com levedura sobre o teor de nitrogênio uréico no leite.

Os teores de nitrogênio uréico no leite variaram de 15,16 a 16,66 mg/dL, estando abaixo do limite de $19 \mathrm{mg} / \mathrm{dL}$ citado por Bruckental et al. (1989). Segundo esse autor, valores de nitrogênio uréico no leite acima de $19 \mathrm{mg} / \mathrm{dL}$ estão associados com problemas reprodutivos em vacas em lactação.

\subsubsection{Nitrogênio uréico e glicose no plasma sangüíneo}

Os teores de nitrogênio uréico no plasma foram menores $(P<0,05)$ nos tratamentos com polpa cítrica. Um fator responsável pela redução dos teores de nitrogênio uréico no plasma, devido à inclusão de polpa cítrica na ração, seria a grande quantidade de carboidratos rapidamente degradáveis no rúmen presente na polpa. Isso favoreceria a utilização do nitrogênio amoniacal pelos microrganismos ruminais e melhoraria o perfil de aminoácidos essenciais na proteína metabolizável (Theurer et al., 1999a), uma vez que o teor de nitrogênio uréico no plasma é afetado por dois fatores principais: teor de nitrogênio 
amoniacal no fluido ruminal e proteína metabolizável com perfil de aminoácidos essenciais inadequado (NRC, 2001).

Resultados discordantes aos do presente estudo foram obtidos por Rocha Filho (1998), Santos et al. (2001b), Nussio et al. (2002) e Scoton (2003), que não observaram efeito da adição de polpa cítrica sobre o teor de nitrogênio uréico plasmático.

A suplementação com aditivo microbiológico não afetou $(P>0,05)$ o teor de nitrogênio uréico no plasma dos animais, assim como nos trabalhos de Higginbotham et al. (1994) e Wohlt et al. (1991; 1998).

Os teores de nitrogênio uréico no plasma estão acima daquele sugerido por Valadares et al. (1997) como limite a partir do qual o animal começa a desperdiçar nitrogênio, que seria entre 13,5 a $15 \mathrm{mg} / \mathrm{dL}$.

Não houve diferença no teor de glicose plasmática entre os diferentes tratamentos $(P>0,05)$. Os valores estão dentro da faixa de variação normal de 42,1 a 74,5 mg/dL, citada por Fraser et al. (1991).

Outros autores também não observaram diferença no teor de glicose plasmática devido a inclusão de polpa cítrica na ração (Lykos et al., 1997; Santos et al., 2001b; Nussio et al., 2002; Scoton, 2003). Oba \& Allen (2003) observaram maior teor de glicose no plasma de animais que foram alimentados com rações contendo maior teor de amido, porém, o teor de amido variou com a inclusão de mais concentrado na ração.

No trabalho de Piva et al. (1993), o teor de glicose foi mais alto no plasma sangüíneo de animais suplementados com aditivo microbiológico. A quantidade de levedura fornecida foi de $10 \mathrm{~g} / \mathrm{d}\left(10 \times 10^{9} \mathrm{ufc} / \mathrm{g}\right)$, juntamente com dieta baseada em silagem de milho e feno de alfafa. Os autores não discutiram as possíveis explicações para maiores teores de glicose plasmática em animais que receberam o aditivo microbiológico. 


\subsection{Conclusões}

Para vacas produzindo ao redor de $19 \mathrm{~kg} / \mathrm{d}$ de leite, no terço final da lactação, a polpa cítrica teve valor energético igual ao do milho quando combinada com este cereal na proporção 1:1.

Vacas no terço final de lactação, com produção de 19 kg/d de leite, não responderam à suplementação com aditivo microbiológico. 


\title{
4 VARIAÇÃO DO TEOR DE AMIDO EM RAÇÕES DE VACAS LEITEIRAS ATRAVÉS DE DIFERENTES PROPORÇÕES DE MILHO MOÍDO E POLPA CÍTRICA PELETIZADA
}

\author{
Autor: CAROLINA DE ALMEIDA CARMO
}

Orientador: Prof. Dr. FLÁVIO AUGUSTO PORTELA SANTOS

\section{Resumo}

Foram utilizadas vinte e oito vacas da raça Holandesa (230 DEL) para avaliação dos efeitos da variação no teor de amido da ração sobre 0 desempenho lactacional. Os tratamentos foram: 15\% (AM15), 20\% (AM20), 25\% (AM25) e 30\% (AM30) de amido na matéria seca da ração. O período experimental foi de 80 dias, sendo quatro subperíodos de 20 dias. 0 delineamento experimental utilizado foi o de Quadrados Latinos 4x4 repetidos. As produções de leite foram 27,94; 29,17; 31,11 e 29,64 kg/d para os tratamentos AM15, AM20, AM25 e AM30, respectivamente, apresentando efeito cúbico significativo $(P<0,05)$. Para produção de gordura, proteína, lactose e sólidos totais do leite também houve efeito cúbico $(P<0,05)$. Para teor de proteína, sólidos totais e nitrogênio uréico no leite houve efeito linear $(P<0,05)$. Não houve efeito dos tratamentos sobre teor de gordura do leite e glicose e nitrogênio uréico plasmáticos $(P>0,05)$.Vacas produzindo em torno de $30 \mathrm{~kg} / \mathrm{d}$ apresentaram melhor desempenho quando alimentadas com rações contendo $25 \%$ de amido, não havendo vantagem no fornecimento de rações com teor de amido de $30 \%$. 
Varying starch contents of dairy cow rations, through different proportions of corn grain and dried citrus pulp

\author{
Author: CAROLINA DE ALMEIDA CARMO \\ Adviser: Prof. Dr. FLÁVIO AUGUSTO PORTELA SANTOS
}

\title{
Summary
}

Twenty eight lactating Holstein cows (230 days in milk) from the Animal Science Department of the University of São Paulo were used to evaluate the effects on performance of varying contents of starch in the ration. Starch contents was varied by replacing fine ground corn by dried citrus pulp. Treatments were: 15\% (AM15), 20\% (AM20), 25\% (AM25) e 30\% (AM30) of starch in the ration dry matter. Experimental period lasted 80 days, with 4 periods of 20 days in a repeated 4x4 Latin Square Design. Milk yield was 27,94; 29,17; 31,11 e 29,64 kg/d for treatments AM15, AM20, AM25 e AM30 respectively, with cubic effect $(P<0,05)$. Milk fat, protein, lactose and total solids yield were affected cubically $(P<0,05)$. A linear effect was detected for protein, total solids and milk urea nitrogen content $(P<0,05)$. Milk fat content, plasma urea nitrogen and glucose were not affected by treatments $(P>0,05)$. Cows producing about $30 \mathrm{~kg} / \mathrm{d}$ got better performance when fed with rations $25 \%$ starch contents. Did not have advantage by supplying $30 \%$ starch contents rations.

\subsection{Introdução}

No Brasil, a silagem de milho é a principal fonte de forragem para vacas leiteiras de alta produção mantidas em confinamento e o milho é a principal fonte de energia dentre os alimentos concentrados. Essas rações apresentam altos teores de amido, com valores entre $26 \%$ a $33 \%$ na MS, que podem 
predispor a um pH ruminal crítico para a degradação de fibra no rúmen e para a manutenção do teor de gordura do leite.

Trabalhos conduzidos recentemente (Santos et al., 2001b; Nussio et al., 2002) sugerem que os teores de amido total e de amido degradável no rúmen, propostos como adequados nos trabalhos revisados por Theurer et al. (1999a) e que continham alfafa como principal fonte de forragem, podem ser excessivos quando o volumoso é, principalmente, silagem de milho. A maior parte dos estudos revisados por Theurer et al. (1999a) indicam que em rações com 28\% a $32 \%$ de amido baseadas em alfafa, a produção de leite é maior quando as fontes de amido são processadas (floculação). Porém, os teores de gordura do leite observados nestes trabalhos estavam abaixo de 3,5\%. Vacas de alta produção alimentadas com silagem de milho poderiam apresentar teor de gordura do leite um pouco mais baixo, comparadas àquelas que ingeriram alfafa em rações com teor de amido em torno de $28 \%$ a 32\%. Nessas situações, a substituição parcial de grãos de cereais por uma fonte de carboidratos de rápida fermentação e com baixo teor de amido poderia ser benéfica (Santos et al., 2001b).

Maior produção de leite corrigido para 3,5\% de gordura também foi relatada por Nussio et al (2002), quando o teor de amido total da ração foi reduzido, através da substituição parcial do milho moído fino ou floculado, por polpa cítrica peletizada.

Durante os últimos anos, a utilização da polpa cítrica peletizada no Brasil tem crescido significativamente, devido a grande disponibilidade e aos preços competitivos. Estudos indicam que para vacas produzindo entre 15 a $22 \mathrm{~kg} / \mathrm{d}$ de leite, tanto confinadas (Santos et al., 2001b, Nussio et al., 2002) como em pastagens tropicais (Martinez, 2004), a substituição de $50 \%$ do milho ou mais por polpa cítrica peletizada não tem efeitos negativos na produção e composição do leite. A combinação de milho floculado com polpa cítrica (proporção 50:50) melhorou o desempenho de vacas leiteiras, comparado ao milho moído grosso ou milho floculado (Santos et al., 2001b). 
Esse trabalho teve o objetivo de avaliar o efeito da variação do teor de amido sobre o desempenho lactacional em rações para vacas leiteiras alimentadas com silagem de milho, através da combinação de diferentes proporções de milho moído e polpa cítrica peletizada.

\subsection{Material e Métodos}

\subsubsection{Local e Animais}

O experimento foi conduzido nas instalações do Departamento de Zootecnia da Escola Superior de Agricultura "Luiz de Queiroz", Universidade de São Paulo, entre os meses de agosto a outubro de 2002 .

As instalações constaram de um sistema de confinamento do tipo "freestall" com quatro lotes, contendo 12 baias por lote.

Foram utilizadas vinte e oito vacas da raça Holandesa, com período médio de lactação de 230 dias ( \pm 170) e produção média de 28 kg/d de leite. Esses valores foram tomados como média no meio do experimento.

\subsubsection{Tratamentos}

Foram estudados teores crescentes de amido total nas rações de vacas em lactação que receberam silagem de milho como volumoso, através de combinações entre milho moído fino (tamanho médio de partícula de 1,2 mm) e polpa cítrica peletizada. As rações foram formuladas através do programa NRC (2001) para suprirem quantidades adequadas de proteína degradável no rúmen e proteína metabolizável. Os ingredientes utilizados foram: silagem de milho, milho moído fino, polpa cítrica peletizada, farelo de soja, farelo de algodão, suplemento mineral e vitamínico e bicarbonato de sódio (Tabela 4). 
Tabela 4. Composição das dietas experimentais

\begin{tabular}{lcccc}
\hline & AM15 $^{1}$ & AM20 & AM25 & AM30 \\
& \multicolumn{3}{c}{$\%$ da MS } \\
\hline Silagem de milho & 45,00 & 44,97 & 44,96 & 44,96 \\
Milho moído fino & 6,79 & 13,11 & 19,01 & 26,26 \\
Polpa cítrica peletizada & 19,43 & 13,11 & 7,25 & 0,00 \\
Farelo de soja & 9,78 & 9,77 & 9,78 & 9,78 \\
Farelo de algodão & 15,52 & 15,51 & 15,52 & 15,52 \\
Supl. Min. Vit. $^{2}$ & 2,77 & 2,78 & 2,75 & 2,75 \\
Bicarbonato de Na & 0,72 & 0,74 & 0,74 & 0,74
\end{tabular}

${ }^{1}$ AM15= 15\% de amido na MS da ração; AM20 = 20\% de amido na MS da ração; AM25= $25 \%$ de amido na MS da ração; $A M 30=30 \%$ de amido na MS da ração.

${ }^{2}$ Supl. Min. Vit.= Suplemento Mineral e Vitamínico, contendo por kg de suplemento: 55,0 g de Fósforo ; 220,0 g de Cálcio, 105,5 g de Cloro; 70,0 g de Sódio; 35,0 g de Magnésio; 22,0 g de Enxofre; 1500,0 mg de Manganês; 500,0 mg de Ferro; 1550,0 mg de Zinco; 450,0 mg de Cobre; 50,0 mg de Cobalto; 40,0 mg de lodo; 20,0 mg de Selênio; 550,0 mg de Flúor; $90000 \mathrm{UI}$ de Vitamina $A ; 75000$ UI de Vitamina $D_{3}$ e 1000 UI de Vitamina $E$.

\subsubsection{Período experimental e coleta de dados}

O período experimental teve a duração de 80 dias divididos em quatro subperíodos de 20 dias. Os 16 primeiros dias foram para adaptação dos animais às rações e os outros quatro dias para coleta de dados.

A condição corporal foi avaliada e os animais foram pesados, no início e no final de cada subperíodo experimental, utilizando-se a escala de 1 a 5 de acordo com Wildman et al. (1982).

Os animais foram ordenhados às 6:00 e às 18:00, e as produções de leite individuais registradas nos quatro dias de coleta de dados, através de medidores do tipo "Mark V". Amostras de leite de cada vaca foram coletadas também nesses dias, nas ordenhas da manhã e da tarde, sendo compostas por dia e analisadas para gordura, proteína, lactose e sólidos totais, pelo processo de infravermelho através do analisador Bentley 2000 (Bentley Instruments); e 
nitrogênio uréico pelo analisador ChemSpec 150 (Bentley Instruments) no Laboratório da Clínica do Leite do Departamento de Zootecnia da Escola Superior de Agricultura "Luiz de Queiroz", Universidade de São Paulo.

As rações foram distribuídas às 6:00 e às 18:00, e as sobras de alimento foram mensuradas e descartadas diariamente antes do fornecimento do período da tarde. O consumo de alimento foi medido em grupo, por tratamento, diariamente, durante os quatro dias de coleta de dados.

Amostras das rações e das sobras foram retiradas nos quatro dias de coleta de dados. A silagem foi amostrada semanalmente e os outros alimentos no início de cada período de coleta de dados, sendo as amostras de silagem armazenadas $\mathrm{a}-18^{\circ} \mathrm{C}$. Subamostras da silagem foram secadas imediatamente após a amostragem, a $105^{\circ} \mathrm{C}$ por 24 horas para determinação da MS, a fim de ajustar a quantidade de silagem a ser fornecida.

Após o período experimental, as amostras de alimentos e rações foram secadas a $55^{\circ} \mathrm{C}$ (em estufa com circulação forçada de ar por 72 horas) e analisadas para MS (três horas em estufa a $105^{\circ} \mathrm{C}$ ), para matéria orgânica (MO) (três horas em mufla a $600^{\circ} \mathrm{C}$ ), para FDN e FDA através do digestor Ankom, de acordo com Van Soest et al. (1991), para proteína bruta (PB) através de condução térmica no equipamento Leco FP 528 (Leco Corporation, St. Joseph MI) e, para amido, segundo método descrito por Poore et al. (1993a). Foi determinada apenas a MS das amostras de sobras, para cálculo da ingestão de matéria seca pelos animais. As análises foram realizadas no Laboratório de Bromatologia do Departamento de Zootecnia da Escola Superior de Agricultura “Luiz de Queiroz", Universidade de São Paulo.

As amostras de sangue foram coletadas em tubos com fluoreto de sódio como antiglicolítico, e oxalato de potássio como anticoagulante, no último dia de coleta de dados, quatro horas após alimentação. As amostras foram centrifugadas em 3000 x g por 20 minutos, armazenadas em tubos de $2 \mathrm{~mL}$ tipo "eppendorf" a $-10^{\circ} \mathrm{C}$, e posteriormente analisadas para glicose através do Analisador Bioquímico YSI 2700S (Yellow Springs Instrument Co. Inc., Ohio, 
USA) e, para uréia, através do Kit Analisa (Analisa Indústria e Comércio Ltda.), método colorimétrico. As análises de glicose foram realizadas no Laboratório de Bromatologia do Departamento de Zootecnia da Escola Superior de Agricultura “Luiz de Queiroz", Universidade de São Paulo e as análises de uréia no Biomed Laboratórios de Análises Clínicas. O valor obtido de uréia foi convertido para nitrogênio uréico, considerando-se $46,6 \%$ de nitrogênio na uréia.

\subsubsection{Delineamento experimental e análise estatística}

O delineamento experimental utilizado foi o de Quadrados Latinos 4 × 4 repetidos. Foram utilizados vinte e oito animais distribuídos em sete Quadrados Latinos.

Os dados de consumo foram analisados como um Quadrado Latino simples, onde cada grupo de animais, de cada tratamento, foi considerado a unidade experimental, em virtude do consumo de alimento ter sido medido em grupo e não individualmente.

Os dados foram analisados pelo PROC GLM (General Linear Models) do programa estatístico SAS (1999), versão 8 para Windows. Foi feita análise de regressão polinomial de $1^{\circ}, 2^{\circ}$ e $3^{\circ}$ grau. Considerou-se o nível de significância de 5\%, e até 10\% como tendência de significância para a probabilidade do teste F.

\subsection{Resultados e Discussão}

Os dados da análise bromatológica dos ingredientes são apresentados na Tabela 5. O teor de FDA da polpa cítrica está abaixo dos valores citados no NRC (2001). Também foram observados altos valores para o FDN do farelo de soja e para o amido da polpa cítrica, comparados aos valores do NRC (2001). A composição das rações foi estimada a partir dos resultados dos ingredientes. Nesses cálculos, o teor de amido da polpa cítrica foi considerado como sendo 
0,5\%, por estar mais próximo aos valores encontrados na literatura (Wainman \& Dewey, 1988; Mertens, 1992, citado por Carvalho, 1995).

Tabela 5. Composição bromatológica dos ingredientes e rações

\begin{tabular}{lcccccc}
\hline & & & \multicolumn{3}{c}{$\%$ da MS } \\
& MS (\%) & MO & PB & FDN & FDA & Amido \\
\hline Silagem de milho & 26,82 & 95,38 & 7,43 & 49,39 & 30,10 & 17,15 \\
Milho moído fino & 88,47 & 98,74 & 8,06 & 7,86 & 1,67 & 76,23 \\
Polpa cítrica peletizada & 88,96 & 94,34 & 7,26 & 22,82 & 15,80 & * \\
Farelo de algodão & 92,77 & 94,12 & 44,52 & 36,55 & 16,66 & 7,73 \\
Farelo de soja & 89,91 & 94,00 & 47,59 & 16,74 & 7,40 & 9,81 \\
Rações & & & & & & \\
AM15 & 47,67 & 92,77 & 18,06 & 32,64 & 18,78 & 14,80 \\
AM20 & 47,62 & 93,04 & 18,13 & 31,60 & 17,79 & 20,12 \\
AM25 & 47,57 & 93,36 & 18,21 & 30,65 & 16,88 & 25,11 \\
AM30 & 47,50 & 93,72 & 18,30 & 29,46 & 15,74 & 31,30
\end{tabular}

${ }^{1}$ AM15 = 15\% de amido na MS da ração; AM20= 20\% de amido na MS da ração; AM25= 25\% de amido na MS da ração; $\mathrm{AM} 30=30 \%$ de amido na MS da ração.

* considerado valor de tabela de $0,5 \%$.

Os pesos vivos e escores da condição corporal médios de todos os animais, no início e no final do período experimental foram $595 \mathrm{~kg}, 632 \mathrm{~kg}, 2,9$ e 3,0, respectivamente. Os dados de ingestão de MS, eficiência alimentar, produção e composição do leite, nitrogênio uréico e glicose plasmáticos e variação do peso e do escore da condição corporal são apresentados na Tabela 6. 
Tabela 6. Ingestão de matéria seca, eficiência alimentar, produção e composição do leite, nitrogênio uréico e glicose plasmáticos e variação do peso e do escore da condição corporal

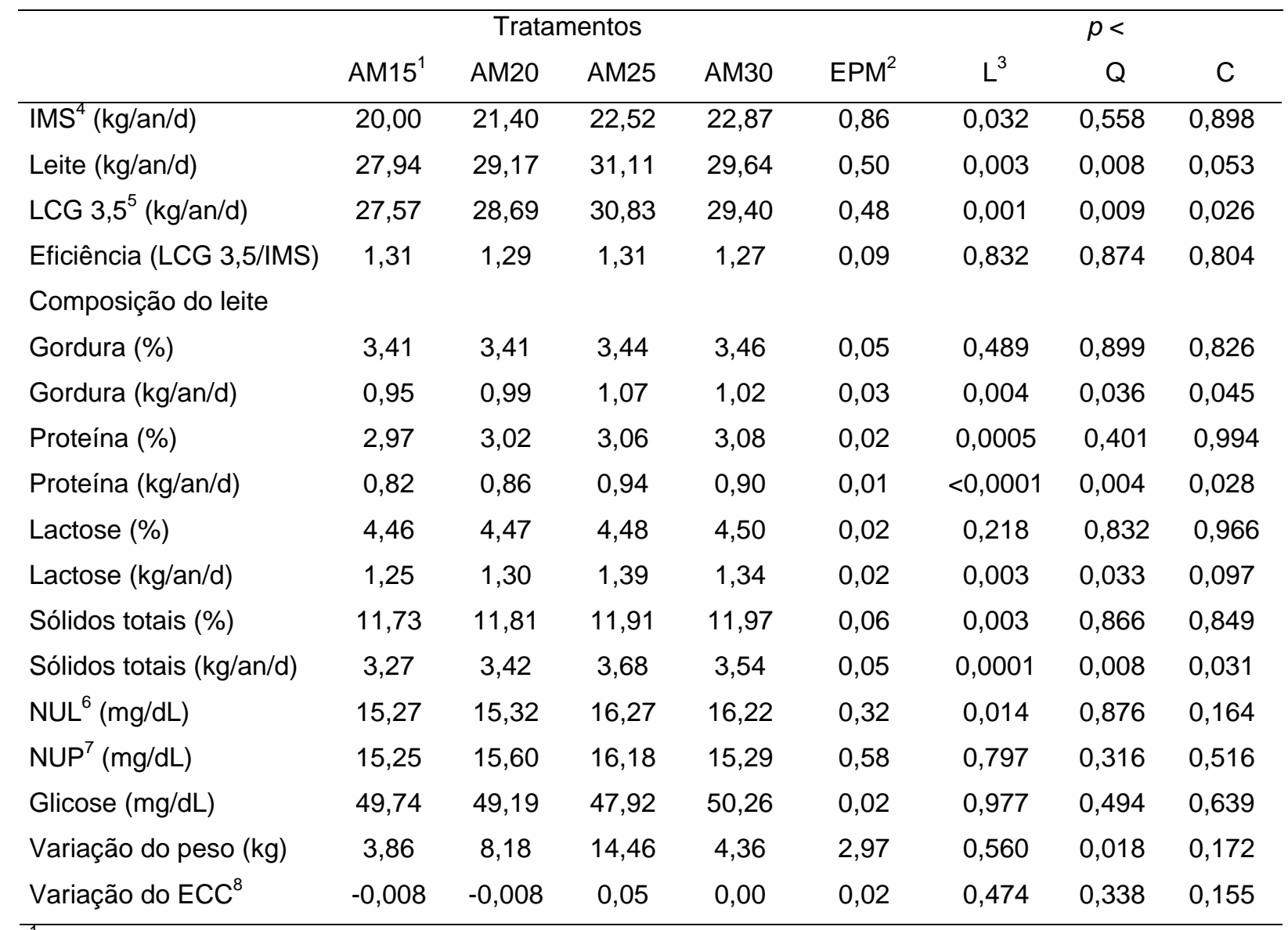

${ }^{1} A M 15=15 \%$ de amido na MS da ração; AM20 = 20\% de amido na MS da ração; AM25= 25\% de amido na MS da ração; $A M 30=30 \%$ de amido na MS da ração.

${ }^{2} E P M=$ erro padrão da média.

${ }^{3} \mathrm{~L}=$ efeito linear; $\mathrm{Q}=$ efeito quadrático; $\mathrm{C}=$ efeito cúbico.

${ }^{4} \mathrm{IMS}=$ ingestão de matéria seca.

${ }^{5}$ LCG 3,5= leite corrigido para teor de gordura igual a 3,5\%.

${ }^{6} \mathrm{NUL}=$ nitrogênio uréico no leite.

${ }^{7} \mathrm{NUP}=$ nitrogênio uréico no plasma.

${ }^{8} \mathrm{ECC}=$ escore da condição corporal. 


\subsubsection{Ingestão de matéria seca}

Houve efeito linear do aumento do teor de amido sobre a ingestão de MS $(P<0,05)$. O aumento na ingestão de MS com a diminuição da proporção de polpa cítrica na ração difere do ocorrido nos trabalhos de Santos et al. (2001b), Nussio et al. (2002), Scoton (2003) e Assis et al. (2004a), onde não houve efeito da substituição parcial do milho por polpa cítrica sobre a ingestão de MS. A principal diferença entre esse estudo e os demais citados é que a produção de leite por vaca foi superior no presente trabalho. A hipótese inicial de que teores de amido ao redor de $30 \%$ da MS da ração seriam excessivos, quando o volumoso principal fosse silagem de milho, não se confirmou quanto aos possíveis efeitos negativos na ingestão de MS.

Em trabalho de Solomon et al. (2000), a ingestão de MS também foi maior para o tratamento com alto teor de amido (milho), comparado ao tratamento com alto teor de pectina (polpa cítrica).

O teor de FDN das rações caiu de 32,6 para $29,4 \%$ na MS da ração, à medida que o teor de amido aumentou de 15 para 31,3\% na ração. De acordo com o NRC (2001), teores de carboidratos não fibrosos (CNF) de 47,1\% estão acima do recomendado para rações com teores de FDN ao redor de 29\%, especialmente se considerarmos que a maior parte dos CNF são representados por amido (30\% na MS) nessa ração. Entretanto, os dados de ingestão de MS não sugerem que tenha havido excesso de CNF ou inadequação de fibra efetiva nas rações com alto teor de amido.

\subsubsection{Produção de leite}

Houve efeito cúbico do teor de amido sobre a produção de leite (figura 1) e produção de LCG 3,5 $(P<0,05)$. Semelhantemente ao ocorrido no trabalho de Leiva et al. (2000), que observaram maiores produções de leite e LCG 3,5 em vacas alimentadas com ração contendo maior teor de amido (relação 
milho:polpa $=70: 30$ ), quando comparadas àquelas alimentadas com ração contendo menor teor de amido (relação milho:polpa = 30:70).

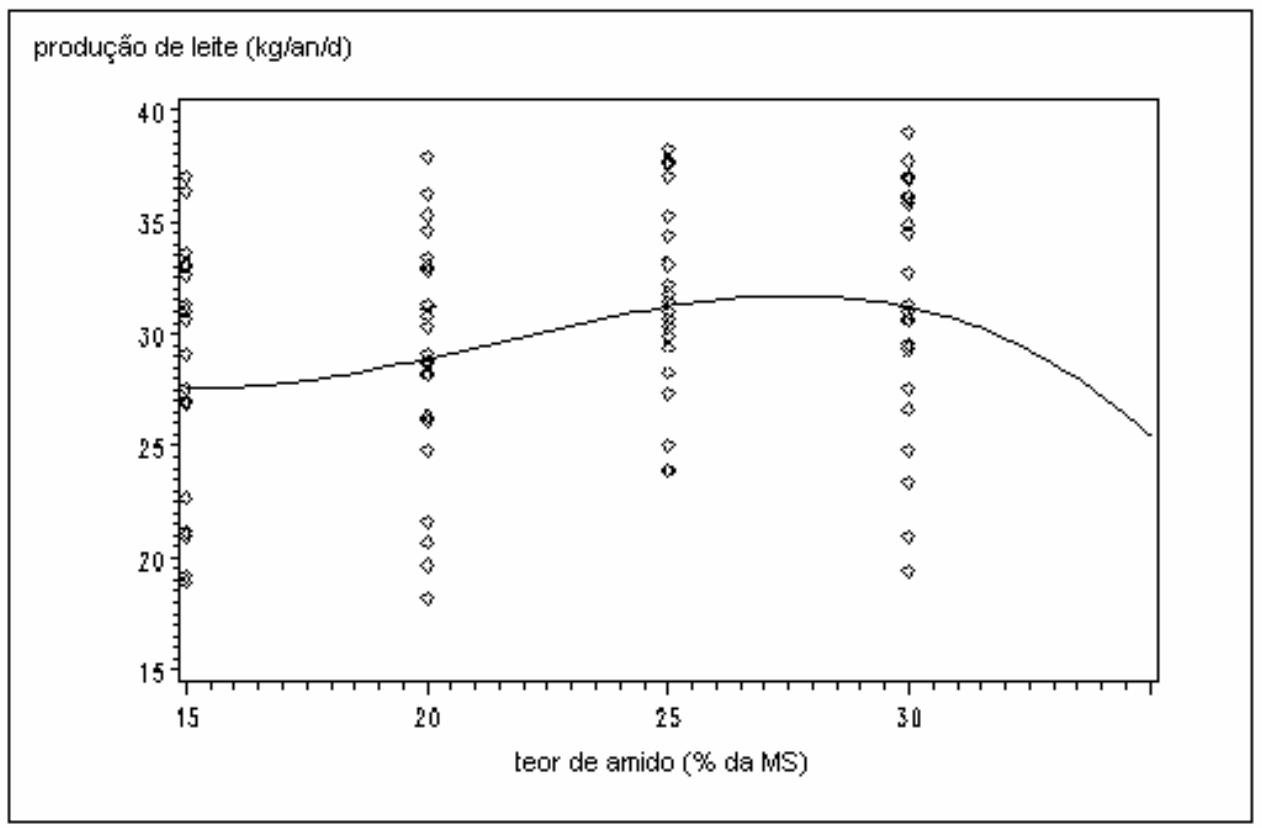

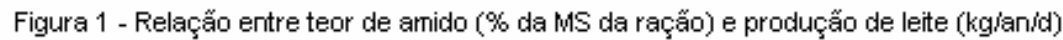

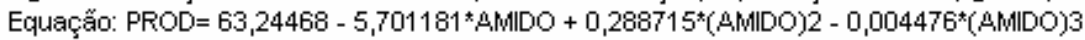

Os trabalhos de Santos et al. (2001b), Nussio et al. (2002) e Scoton (2003) mostraram que, para vacas produzindo entre 19 a $23 \mathrm{~kg} / \mathrm{d}$ de leite e alimentadas com rações contendo silagem de milho como volumoso, a redução do teor de amido da ração de 30-32\% para 21-23\% não apresentou efeito negativo, ocorrendo, inclusive, efeito positivo no desempenho das vacas em alguns desses estudos.

Resultados semelhantes aos desses autores foram encontrados por Assis et al. (2004a) que não observaram diferenças na produção de leite quando avaliaram diversos teores de substituição de milho moído por polpa cítrica. A produção média dos animais, nesse caso, foi de $20 \mathrm{~kg} / \mathrm{d}$. Solomon et al. (2000) também não observaram diferenças na produção de leite quando forneceram rações contendo alto teor de amido ou alto de teor de pectina, para vacas produzindo em torno de $35 \mathrm{~kg} / \mathrm{d}$. 
Os dados deste trabalho sugerem que vacas produzindo ao redor de 31 $\mathrm{kg} / \mathrm{d}$ de leite respondem a teores de amido de $25 \%$ na MS da ração. Porém, o aumento do teor de amido para 30\% da MS não melhorou o desempenho das vacas em comparação com o teor de amido de $25 \%$.

A maior produção de leite observada nos animais alimentados com ração contendo $25 \%$ de amido, em comparação com $15 \%$ e $20 \%$ de amido, está de acordo com o NRC (2001), que apresenta valores de energia mais elevados para milho moído fino que para polpa cítrica.

A fermentação ruminal do amido tende a produzir mais nutrientes glucogênicos do que a fermentação de pectina e FDN. Uma vez que a quantidade de lactose produzida determina a produção de leite, a disponibilidade de precursores glucogênicos da ração é um dos fatores que pode afetar a produção de leite. As diferenças em produção e eficiência de animais alimentados com rações contendo diferentes quantidades de milho e polpa cítrica poderiam ser explicadas se a ração com polpa fornecesse menores quantidades de precursores glucogênicos do que a ração com milho, e se uma maior proporção dos aminoácidos absorvidos fosse utilizada para produção de glicose.

No presente estudo, a maior produção de leite na ração contendo $25 \%$ de amido, em comparação àquelas contendo 15\% e 20\%, pode ser explicada pelo aumento linear na IMS. A quantidade de MS ingerida supriu nutrientes suficientes para justificar a produção extra de leite.

A queda na produção de leite no tratamento contendo $30 \%$ de amido sugere que, apesar da IMS não ter sido alterada, alterações negativas podem ter ocorrido na fermentação ruminal devido ao provável excesso de amido na ração. 


\subsubsection{Eficiência alimentar}

Não houve efeito $(P>0,05)$ dos teores de amido sobre a eficiência alimentar (LCG 3,5 / IMS), assim como nos trabalhos de Leiva et al. (2000) e Scoton (2003), contrastando-se com os dados de Santos et al. (2001b) e Andrade (2002), onde a substituição do milho por polpa cítrica aumentou a eficiência alimentar. A ausência de diferença na eficiência alimentar nas rações com polpa cítrica e milho confirmam que a polpa cítrica tem valor energético igual ao do milho para vacas produzindo até $30 \mathrm{~kg} / \mathrm{d}$ de leite, e que alterações na produção de leite devem-se a variações na IMS.

\subsubsection{Composição do leite}

Não houve efeito do teor de amido sobre o teor de gordura do leite $(P>0,05)$, semelhantemente ao observado por Solomon et al. (2000), Bargo et al. (2003), Scoton (2003), Assis et al. (2004a), Martinez (2004) e Moreira et al. (2004). Os dados desse trabalho concordam com a hipótese de que a polpa seria mais efetiva no aumento do teor da gordura do leite quando este fosse baixo.

Em trabalho de Leiva et al. (2000) o teor de gordura do leite foi maior para animais alimentados com ração com relação milho:polpa de 30:70.

Apesar da ausência de efeito negativo do alto teor amido (30\%) no teor de gordura do leite não sugerir que este teor seja excessivo, a tendência de redução na produção de leite indica o contrário.

Houve efeito cúbico do teor de amido sobre a produção de gordura do leite $(P<0,05)$, em conseqüência das diferenças de produção de leite entre os tratamentos.

O teor de proteína do leite aumentou com a diminuição da proporção de polpa cítrica na ração $(P<0,05)$ e houve efeito cúbico sobre a produção de proteína do leite $(P<0,05)$. Resultados semelhantes foram obtidos por Santos et 
al. (2001b) que observaram tendência de diminuição no teor de proteína do leite quando incluíram polpa cítrica na ração, e por Moreira et al. (2004), quando a substituição de milho moído por polpa cítrica reduziu o teor de proteína do leite. Resultados contrastantes foram obtidos por Solomon et al. (2000) que observaram aumento no teor de proteína do leite dos animais alimentados com ração contendo maior teor de amido, comparados aos que foram alimentados com ração contendo alto teor de pectina.

O aumento nos teores de proteína do leite nas rações com teores mais elevados de amido pode ser resultado de uma maior síntese de proteína microbiana nessas rações associada à maior disponibilidade de propionato para o fígado. Maior fluxo de proteína metabolizável para o intestino, associado à menor utilização de aminoácidos essenciais para a gluconeogênese hepática, pode resultar em maior disponibilidade de aminoácidos essenciais para a glândula mamária.

Em estudo de fermentação in vitro (Rosendo et al., 1999), foi observada menor produção de proteína microbiana proveniente de pectina, comparada com a mesma quantidade de substrato amiláceo. Nesse estudo, a fermentação de pectina chegou ao seu menor valor de $\mathrm{pH}$ algumas horas antes do que a de amido, sugerindo que a pectina fermenta mais rapidamente que o amido.

Os teores de lactose não diferiram entre os tratamentos $(P>0,05)$ e as produções de lactose apresentaram tendência de efeito cúbico $(P<0,10)$, diferentemente dos dados de Solomon et al. (2000), Scoton (2003) e Moreira et al. (2004), onde não foram observadas diferenças na lactose do leite quando substituíram milho por polpa cítrica.

Houve efeito linear do aumento do teor de amido sobre o teor de sólidos totais $(P<0,05)$ e efeito cúbico sobre a produção de sólidos totais do leite $(P<0,05)$. No trabalho de Scoton (2003), onde a substituição parcial do milho por polpa cítrica foi avaliada, não houve diferença no teor e produção de sólidos totais do leite. 
O teor de nitrogênio uréico no leite aumentou linearmente com o aumento do teor de amido da ração $(P<0,05)$, porém permaneceu abaixo do valor crítico de $19 \mathrm{mg} / \mathrm{dL}$, valor esse associado com problemas reprodutivos de acordo com Bruckental et al. (1989). Esses dados foram semelhantes aos de Moreira et al. (2004), mas diferem dos observados por Leiva et al. (2000), onde o teor de nitrogênio uréico no leite foi maior para o tratamento com menor teor de amido, ou seja, maior quantidade de polpa cítrica em relação ao milho na ração.

Em trabalho de Solomon et al. (2000), o teor de nitrogênio uréico no leite não diferiu entre animais alimentados com rações com maior quantidade de milho moído ou maior quantidade de polpa cítrica peletizada.

\subsubsection{Nitrogênio uréico e glicose no plasma sangüíneo}

Não houve efeito dos tratamentos $(P>0,05)$ sobre os teores de nitrogênio uréico no plasma, estando os valores bem próximos da faixa de 13,5 a 15 $\mathrm{mg} / \mathrm{dL}$, que, segundo Valadares et al. (1997), representa máxima eficiência microbiana. Santos et al. (2001b) e Nussio et al. (2002) também não observaram alteração no teor de nitrogênio uréico no plasma com o aumento no teor de amido na ração.

Apesar da ausência de efeito dos tratamentos no teor de nitrogênio uréico no plasma, houve efeito no teor de nitrogênio uréico no leite. De modo geral, esses valores são correlacionados positivamente, o que não foi observado no presente estudo.

Não houve diferença no teor de glicose no plasma sangüíneo entre os animais que receberam os diferentes tratamentos $(P>0,05)$, assim como nos trabalhos de Lykos et al. (1997), Santos et al. (2001b), Nussio et al. (2002) e Scoton (2003).

Os teores de glicose plasmática estão dentro das variações consideradas normais de 35 a 55 mg/dL, de acordo com Blood \& Radostits (1989) e de 42,1 a $74,5 \mathrm{md} / \mathrm{dL}$, conforme Fraser (1989). 


\subsection{Conclusões}

A combinação de uma fonte energética rica em pectina e fibra de alta digestibilidade (polpa cítrica) e uma fonte amilácea (milho), para resultar em ração contendo $25 \%$ de amido, propiciou maior produção de leite do que ração composta exclusivamente com fonte amilácea contendo teor de amido ao redor de $30 \%$.

Para vacas com produção ao redor de 29 a $31 \mathrm{~kg} / \mathrm{d}$ de leite, a polpa cítrica tem valor energético semelhante ao milho, independentemente da proporção na qual é combinada com este cereal. 


\section{GRAU DE MOAGEM DO MILHO EM COMBINAÇÃO COM POLPA CÍTRICA PELETIZADA OU CASCA DE SOJA EM RAÇÕES PARA VACAS LEITEIRAS NO TERÇO MÉDIO DA LACTAÇÃO}

Autor: CAROLINA DE ALMEIDA CARMO

Orientador: Prof. Dr. FLÁVIO AUGUSTO PORTELA SANTOS

\section{Resumo}

Trinta e duas vacas da raça Holandesa (160 DEL) da Escola Superior de Agricultura "Luiz de Queiroz", Universidade de São Paulo, foram utilizadas para avaliar o efeito sobre o desempenho lactacional do grau de moagem do milho (moído fino ou moído grosso) em combinação com polpa cítrica peletizada ou casca de soja, como fontes de energia na ração, contendo silagem de milho como volumoso. O período experimental teve a duração de 56 dias, divididos em quatro períodos de 14 dias. Os tratamentos foram: milho moído fino + polpa cítrica (MFPC); milho moído grosso + polpa cítrica (MGPC); milho moído fino + casca de soja (MFCS); e, milho moído grosso + casca de soja (MGCS). As vacas foram agrupadas em oito Quadrados Latinos 4x4. A ingestão de matéria seca, produção de leite, teores de gordura, proteína e lactose do leite, glicose e nitrogênio uréico plasmáticos não foram afetados pelos tratamentos $(P>0,05)$. Houve efeito significativo da interação grau de moagem versus fonte de subproduto $(P<0,05)$ para produção de leite corrigido para gordura, produção de gordura e de sólidos totais do leite. O grau de moagem do milho e o tipo de 
subproduto não afetaram o desempenho de vacas leiteiras com produção ao redor de $24 \mathrm{~kg} / \mathrm{d}$ d.

\section{Coarse or Fine Ground Corn Combined with Dried Citrus Pulp or Soy Hulls in Mid Lactating Dairy Cow Rations}

Author: CAROLINA DE ALMEIDA CARMO

Adviser: Prof. Dr. FLÁVIO AUGUSTO PORTELA SANTOS

\section{Summary}

Thirty two mid lactating Holstein cows (160 DIM) from the Animal Science Department of the University of São Paulo were used to study the effects on cow performance of corn grain grinding (coarse or fine grinding), and its combination with dried citrus pulp or soy hulls as energy sources, in the total mixed rations containing corn silage as forage. Experimental period lasted 56 days, divided in four periods of 14 days each. The treatments were: fine ground corn + citrus pulp (MFPC); coarse ground corn + citrus pulp (MGPC); fine ground corn + soy hulls (MFCS); and coarse ground corn + soy hulls (MGCS). Cows were grouped in eight $4 \times 4$ Latin Squares. Treatments did not affect DMI, milk yield, milk fat, protein and lactose contents, plasma urea nitrogen and glucose $(P>0,05)$. The interaction between corn grain grinding and byproduct source was significative for fat corrected milk, fat and total solids yields $(P<0,05)$. Corn grain grinding and byproduct variety did not affect the cows performance with $24 \mathrm{~kg} / \mathrm{d}$ milk yield. 


\subsection{Introdução}

Os grãos de cereais são algumas das principais fontes de energia em rações para vacas leiteiras de alta produção. Maximizar a digestibilidade destes cereais é uma das formas mais eficientes para se aumentar o consumo de energia do animal. Uma alternativa para se aumentar a digestibilidade dos grãos de cereais é otimizar o seu processamento (Theurer et al., 1999a).

Em sua revisão, Theurer et al. (1999a) mostraram de forma consistente que o processamento de milho e sorgo na forma floculada favorece o desempenho produtivo de vacas leiteiras em comparação com a moagem ou laminação. A moagem fina tem se mostrado vantajosa em relação à moagem grosseira em alguns estudos (Nussio et al., 2002; Dhiman et al., 2002). Entretanto, são escassos os estudos com processamento de grãos para vacas alimentadas com silagem de milho como volumoso exclusivo.

A análise dos dados disponíveis na literatura até o momento não nos permite afirmar se existe um teor ideal de amido total e de amido degradável no rúmen, em rações para vacas leiteiras, cujo volumoso principal seja a silagem de milho. Também são escassos na literatura dados sobre os efeitos da redução no teor de amido na ração, através da substituição de grãos de cereais por subprodutos não amiláceos, como polpa cítrica e casca de soja e em rações contendo silagem de milho.

A polpa cítrica tem sido utilizada em crescente escala no Brasil para vacas leiteiras, em substituição parcial ou total ao milho. A polpa é rica em fibra de alta digestibilidade, em pectina e açúcares (Waiman \& Dewey, 1998; Faria et al., 1972).

Em alguns estudos (Santos et al., 2001b; Nussio et al., 2002; Martinez, 2004; Scoton, 2003; Moreira et al., 2004) onde a polpa cítrica substituiu 50\% do milho da ração, a produção das vacas não foi afetada negativamente (vacas com produção abaixo de $25 \mathrm{~kg} / \mathrm{d}$ de leite). 
A casca de soja é composta principalmente de fibra, que tem pouco valor na alimentação humana e no uso industrial. No entanto, suas características fisico-químicas, a facilidade de aquisição em algumas regiões e seu preço competitivo fazem da casca de soja um alimento interessante para o gado leiteiro.

Em adição ao potencial de ser uma alternativa econômica, a substituição de grãos de cereais por casca de soja em rações para vacas leiteiras pode contribuir para um ambiente ruminal mais favorável para a digestão de fibra e menor risco de acidose. Alternativamente, a casca de soja pode ser usada como uma fonte de fibra em substituição parcial ao volumoso.

Ipharraguerre \& Clark (2003) fizeram análises de regressão múltipla utilizando dados de estudos selecionados para avaliar a relação entre o desempenho de vacas leiteiras e a substituição do milho pela casca de soja. Em treze de quinze estudos, não houve diferença na ingestão de matéria seca entre animais alimentados com dietas controle e aqueles que receberam casca de soja. A correlação entre produção de leite e a porcentagem de casca de soja na ração, em dez estudos, foi baixa e não significativa. O teor de gordura do leite não se correlacionou com o teor de casca de soja na ração ou com o teor de FDN provindo da casca de soja, em dez dos quinze estudos revisados por Ipharraguerre \& Clark (2003).

O presente trabalho teve o objetivo de contribuir com informações dentro desse contexto, avaliando o desempenho de vacas em lactação recebendo rações com diferentes graus de moagem do milho (moagem fina ou grossa) e em combinação com polpa cítrica peletizada ou casca de soja. 


\subsection{Material e Métodos}

\subsubsection{Local e Animais}

O experimento foi conduzido nas instalações do Departamento de Zootecnia da Escola Superior de Agricultura "Luiz de Queiroz", Universidade de São Paulo, entre os meses de dezembro de 2002 a fevereiro de 2003.

As instalações constaram de um sistema de confinamento do tipo "freestall" com quatro lotes, contendo 12 baias por lote.

Foram utilizadas trinta e duas vacas da raça Holandesa, com período médio de lactação de 160 dias ( \pm 160) e produção média de 24 kg/d de leite. Esses valores foram tomados como médias no meio do experimento.

\subsubsection{Tratamentos}

O trabalho visou estudar a combinação de diferentes graus de moagem do milho - moído fino (tamanho médio de partícula =0,97 $\mathrm{mm}$ ) e moído grosso (tamanho médio de partícula = 2,05 mm), com duas fontes de carboidratos não estruturais não amiláceos, que são a polpa cítrica peletizada e a casca de soja, em rações para vacas leiteiras. Para determinação do tamanho médio de partículas do milho moído utilizou-se a técnica de peneiras, descrita por Yu et al. (1998). Na tabela 7 estão os valores de tamanho médio de partículas obtidos. As rações foram formuladas através do programa NRC (2001) para suprirem quantidades adequadas de proteína degradável no rúmen e proteína metabolizável. Os ingredientes utilizados foram: silagem de milho, milho moído, farelo de algodão, polpa cítrica peletizada, casca de soja, uréia, suplemento mineral e vitamínico e bicarbonato de sódio (Tabela 8). 
Tabela 7. Tamanho médio de partículas do milho processado

\begin{tabular}{|c|c|c|c|c|c|c|c|}
\hline \multicolumn{8}{|c|}{ Tamanho dos furos da peneira $(\mathrm{mm})$} \\
\hline & 4,00 & 2,00 & 1,00 & 0,50 & 0,25 & $\mathrm{PRP}^{2}$ & TMP $^{3}$ \\
\hline & \multicolumn{6}{|c|}{$\%$ retida na peneira } & $(\mathrm{mm})$ \\
\hline$M^{1}$ & 9,17 & 28,94 & 30,36 & 19,05 & 7,72 & 4,97 & 2,05 \\
\hline MF & 0 & 3,46 & 34,97 & 37,16 & 16,27 & 8,13 & 0,98 \\
\hline
\end{tabular}

${ }^{1} \mathrm{MG}=$ milho moído grosso; MF= milho moído fino.

${ }^{2} \mathrm{PRP}=$ partículas retidas no prato.

${ }^{3} \mathrm{TMP}=$ tamanho médio de partículas. Foi calculado, assumindo-se que o milho retido na peneira de 4,00 mm, tem o valor de tamano médio de partículas de 6,00 mm, o qual foi multiplicado pela porcentagem retida na peneira de $4,00 \mathrm{~mm}$. Este valor foi somado ao resultado das médias entre as peneiras maiores e menores, multiplicado pelo percentual retido na peneira menor (ex: MG $4 \mathrm{~mm}+2 \mathrm{~mm} \div 2=3$, que multiplicado por $0,2894=0,8682$ e assim sucessivamente). As partículas que passaram pela peneira de crivo $0,25 \mathrm{~mm}$, foram consideradas como tendo 0,12 $\mathrm{mm}$.

Tabela 8. Composição das dietas experimentais

\begin{tabular}{|c|c|c|c|c|}
\hline & MFPC $^{1}$ & MFCS & MGPC & \multirow[t]{2}{*}{ MGCS } \\
\hline & \multicolumn{3}{|c|}{$\%$ da MS } & \\
\hline Silagem de milho & 45,63 & 45,43 & 45,63 & 45,43 \\
\hline Milho moído fino & 13,23 & 13,27 & 0,00 & 0,00 \\
\hline Milho moído grosso & 0,00 & 0,00 & 13,23 & 13,27 \\
\hline Polpa cítrica peletizada & 13,00 & 0,00 & 13,00 & 0,00 \\
\hline Casca de soja & 0,00 & 13,03 & 0,00 & 13,03 \\
\hline Uréia & 0,92 & 0,48 & 0,92 & 0,48 \\
\hline Farelo de algodão & 23,80 & 24,37 & 23,80 & 24,37 \\
\hline Supl. Min. Vit. ${ }^{2}$ & 2,70 & 2,69 & 2,70 & 2,69 \\
\hline Bicarbonato de $\mathrm{Na}$ & 0,72 & 0,72 & 0,72 & 0,72 \\
\hline
\end{tabular}

${ }^{1} \mathrm{MFPC}=$ milho moído fino + polpa cítrica; MFCS= milho moído fino + casca de soja; MGPC= milho moído grosso + polpa cítrica; MGCS= milho moído grosso + casca de soja.

${ }^{2}$ Supl. Min. Vit.= Suplemento Mineral e Vitamínico, contendo por kg de suplemento: 55,0 g de Fósforo ; 220,0 g de Cálcio, 105,5 g de Cloro; 70,0 g de Sódio; 35,0 g de Magnésio; 22,0 $\mathrm{g}$ de Enxofre; 1500,0 mg de Manganês; 500,0 mg de Ferro; 1550,0 mg de Zinco; 450,0 mg de Cobre; 50,0 mg de Cobalto; 40,0 mg de lodo; 20,0 mg de Selênio; 550,0 mg de Flúor; 90000 UI de Vitamina $A ; 75000$ UI de Vitamina $D_{3}$ e 1000 UI de Vitamina $E$. 


\subsubsection{Período experimental e coleta de dados}

O período experimental teve duração de 56 dias divididos em quatro subperíodos de 14 dias. Os dez primeiros dias foram para adaptação dos animais às rações e os outros quatro dias para coleta de dados. Dez dias de adaptação foram adotados baseado em outros trabalhos que também avaliaram os efeitos do processamento do milho (grau de moagem ou laminação) sobre produção e composição do leite (Joy et al., 1997; Crocker et al., 1998 e Callison et al., 2001).

A condição corporal foi avaliada e os animais foram pesados, no início e no final do período experimental, utilizando-se a escala de 1 a 5 de acordo com Wildman et al. (1982).

Os animais foram ordenhados às 6:00 e às18:00, e as produções de leite individuais foram registradas nos quatro dias de coleta de dados, através de medidores do tipo "Mark V". Amostras de leite de cada vaca foram coletadas também nesses dias, nas ordenhas da manhã e da tarde, sendo compostas por dia e analisadas para gordura, proteína, lactose e sólidos totais, pelo processo de infravermelho através do analisador Bentley 2000 (Bentley Instruments), e nitrogênio uréico pelo analisador ChemSpec 150 (Bentley Instruments) no Laboratório da Clínica do Leite do Departamento de Zootecnia da Escola Superior de Agricultura "Luiz de Queiroz", Universidade de São Paulo.

As rações foram distribuídas às 6:00 e às 18:00, e as sobras de alimento foram mensuradas e descartadas diariamente antes do fornecimento do período da tarde. O consumo de alimento foi medido em grupo, por tratamento, diariamente, durante os quatro dias de coleta de dados.

Amostras das rações e das sobras foram retiradas nos quatro dias de coleta de dados. A silagem foi amostrada semanalmente e os outros alimentos no início de cada período de coleta de dados, sendo as amostras de silagem e rações armazenadas a $-18^{\circ} \mathrm{C}$. Subamostras da silagem foram secadas 
imediatamente após a amostragem, a $105^{\circ} \mathrm{C}$ por 24 horas, para determinação da MS, a fim de ajustar a quantidade de silagem a ser fornecida.

Após o período experimental, as amostras de alimentos e rações foram secadas a $55^{\circ} \mathrm{C}$ (em estufa com circulação forçada de ar por 72 horas) e analisadas para MS (três horas em estufa a $105^{\circ} \mathrm{C}$ ), para matéria orgânica (MO) (três horas em mufla a $600^{\circ} \mathrm{C}$ ), para FDN e FDA através do digestor Ankom, de acordo com Van Soest et al. (1991), para proteína bruta (PB) através de condução térmica no equipamento Leco FP 528 (Leco Corporation, St. Joseph MI), e, para amido, segundo método descrito por Poore et al. (1993a). Foi determinada apenas a MS das amostras de sobras para cálculo da ingestão de matéria seca pelos animais. As análises foram realizadas no Laboratório de Bromatologia do Departamento de Zootecnia da Escola Superior de Agricultura "Luiz de Queiroz", Universidade de São Paulo.

As amostras de sangue foram coletadas em tubos com fluoreto de sódio como antiglicolítico, e oxalato de potássio como anticoagulante, no último dia de coleta de dados, quatro horas após alimentação. As amostras foram centrifugadas em 3000 x g por 20 minutos, armazenadas em tubos de $2 \mathrm{~mL}$ tipo "eppendorf" a $-10^{\circ} \mathrm{C}$, e posteriormente analisadas para glicose através do Analisador Bioquímico YSI 2700 S (Yellow Springs Instrument Co. Inc., Ohio, USA), e, para uréia, pelo Kit Analisa (Analisa Indústria e Comércio Ltda.), método colorimétrico. As análises de glicose foram realizadas no Laboratório de Bromatologia do Departamento de Zootecnia da Escola Superior de Agricultura "Luiz de Queiroz", Universidade de São Paulo e as análises de uréia no Biomed Laboratórios de Análises Clínicas. O valor obtido de uréia foi convertido para nitrogênio uréico, considerando-se $46,6 \%$ de nitrogênio na uréia. 


\subsubsection{Delineamento experimental e análise estatística}

O delineamento experimental utilizado foi o de Quadrados Latinos $4 \times 4$ repetidos, em arranjo fatorial (dois tipos de subprodutos e dois graus de moagem do milho). Foram utilizados 32 animais distribuídos em nove Quadrados Latinos.

Os dados de consumo foram analisados como um Quadrado Latino simples, onde cada grupo de animais, de cada tratamento, foi considerado a unidade experimental, em virtude do consumo de alimento ter sido medido em grupo e não individualmente.

Os dados foram analisados pelo PROC GLM (General Linear Models) do programa estatístico SAS (1999), versão 8 para Windows. Foi feito o teste de comparação de médias dos Quadrados Mínimos. Considerou-se o nível de significância de 5\%, e até $10 \%$ como tendência de significância para a probabilidade do teste $F$ na análise de variância e no teste de comparação de médias.

\subsection{Resultados e Discussão}

Os dados da análise bromatológica dos ingredientes são apresentados na Tabela 9. O teor de MS da silagem de milho esteve abaixo do preconizado, entre 32\% a 35\% (Nussio, 1991). Os valores de FDN e FDA do milho e FDA da polpa cítrica foram menores do que aqueles apresentados nas tabelas do NRC (2001). A composição das rações foi estimada a partir dos resultados dos ingredientes. Nesses cálculos o teor de amido da polpa cítrica foi considerado como $0,5 \%$, por estar mais próximo dos valores encontrados na literatura (Wainman \& Dewey, 1988; Mertens, 1992, citado por Carvalho, 1995). 
Tabela 9. Composição bromatológica dos ingredientes e rações

\begin{tabular}{lcccccc}
\hline & & \multicolumn{5}{c}{$\%$ da MS } \\
& MS (\%) & MO & PB & FDN & FDA & Amido \\
\hline Silagem de milho & 28,39 & 95,09 & 7,54 & 50,41 & 30,88 & 17,00 \\
Milho moído & 89,38 & 98,94 & 9,17 & 6,12 & 1,22 & 73,39 \\
Polpa cítrica peletizada & 89,52 & 93,84 & 6,90 & 23,41 & 15,76 & $*$ \\
Casca de soja & 89,22 & 95,93 & 11,46 & 63,79 & 46,27 & 3,60 \\
Farelo de algodão & 91,79 & 94,54 & 38,79 & 44,95 & 21,68 & 7,14 \\
Rações & & & & & & \\
MFPC & & & & & \\
MFCS & 48,44 & 92,38 & 18,26 & 36,23 & 20,49 & 19,40 \\
MGPC & 48,35 & 93,12 & 17,91 & 42,17 & 24,88 & 20,00 \\
MGCS & 48,44 & 92,38 & 18,26 & 36,23 & 20,49 & 19,40 \\
${ }^{1}$ MFPC= milho moído fino + polpa cítrica peletizada; MFCS= milho moído fino + casca de soja; \\
MGPC= milho moído grosso + polpa cítrica peletizada; MGCS= milho moído grosso + casca de \\
\multicolumn{7}{l}{ soja. * considerado valor de tabela de 0,5\%. }
\end{tabular}

Os pesos vivos e escores de condição corporal médios de todos os animais, no início e no final do experimento, foram 568 kg, 570 kg, 2,75 e 2,75, respectivamente. Na Tabela 10, são apresentados os dados de ingestão de MS, produção e composição do leite, eficiência alimentar, nitrogênio uréico e glicose plasmáticos. 
Tabela 10. Ingestão de matéria seca, eficiência alimentar, produção e composição do leite, nitrogênio uréico e glicose plasmáticos

\begin{tabular}{|c|c|c|c|c|c|c|c|c|}
\hline & \multicolumn{4}{|c|}{ Tratamentos } & \multicolumn{4}{|c|}{$p<$} \\
\hline & MFCS $^{1}$ & MFPC & MGCS & MGPC & $\mathrm{EPM}^{2}$ & $G^{3}$ & $\mathrm{~F}$ & GxF \\
\hline $\mathrm{IMS}^{4}(\mathrm{~kg} / \mathrm{an} / \mathrm{d})$ & 18,16 & 19,14 & 19,71 & 18,41 & 0,70 & 0,57 & 0,82 & 0,14 \\
\hline Leite (kg/an/d) & 24,96 & 24,38 & 24,50 & 24,53 & 0,36 & 0,66 & 0,45 & 0,39 \\
\hline LCG $3,5^{5}(\mathrm{~kg} / \mathrm{an} / \mathrm{d})$ & 25,17 & 23,82 & 24,22 & 25,24 & 0,57 & 0,67 & 0,77 & 0,04 \\
\hline Eficiência (LCG 3,5/IMS) & $1,30^{\mathrm{a}}$ & $1,13^{\mathrm{b}}$ & $1,12^{\mathrm{b}}$ & $1,24^{\mathrm{ab}}$ & 0,05 & 0,48 & 0,60 & 0,02 \\
\hline \multicolumn{9}{|l|}{ Composição do leite } \\
\hline Gordura (\%) & 3,58 & 3,40 & 3,51 & 3,67 & 0,12 & 0,41 & 0,89 & 0,15 \\
\hline Gordura (kg/an/d) & 0,89 & 0,82 & 0,84 & 0,89 & 0,03 & 0,62 & 0,85 & 0,05 \\
\hline Proteína (\%) & 3,05 & 2,99 & 2,98 & 3,00 & 0,03 & 0,34 & 0,49 & 0,17 \\
\hline Proteína (kg/an/d) & 0,75 & 0,72 & 0,72 & 0,73 & 0,01 & 0,47 & 0,55 & 0,06 \\
\hline Lactose (\%) & 4,40 & 4,41 & 4,39 & 4,43 & 0,04 & 0,82 & 0,57 & 0,63 \\
\hline Lactose $(\mathrm{kg} / \mathrm{an} / \mathrm{d})$ & 1,10 & 1,07 & 1,07 & 1,10 & 0,02 & 0,94 & 0,78 & 0,16 \\
\hline Sólidos totais (\%) & 11,95 & 11,71 & 11,80 & 12,04 & 0,13 & 0,51 & 0,98 & 0,06 \\
\hline Sólidos totais (kg/an/d) & 2,96 & 2,83 & 2,86 & 2,96 & 0,05 & 0,85 & 0,74 & 0,02 \\
\hline $\mathrm{NUL}^{6}(\mathrm{mg} / \mathrm{dL})$ & 17,26 & 17,21 & 16,56 & 16,13 & 0,43 & 0,04 & 0,58 & 0,66 \\
\hline $\operatorname{NUP}^{7}(\mathrm{mg} / \mathrm{dL})$ & 15,76 & 16,70 & 16,49 & 15,87 & 0,77 & 0,94 & 0,84 & 0,31 \\
\hline Glicose (mg/dL) & 53,40 & 53,39 & 53,49 & 53,82 & 0,005 & 0,66 & 0,79 & 0,77 \\
\hline
\end{tabular}

${ }^{1}$ MFPC $=$ milho moído fino + polpa cítrica; $M G P C=$ milho moído grosso + polpa cítrica; MFCS= milho moído fino + casca de soja; MGCS= milho moído grosso + casca de soja.

${ }^{2} E P M=$ erro padrão da média.

${ }^{3} \mathrm{G}=$ efeito de granulometria (milho moído fino vs. moído grosso); F= efeito de fonte (polpa cítrica vs. casca de soja); GxF= efeito da interação granulometria $x$ fonte;

${ }^{4} \mathrm{IMS}=$ ingestão de matéria seca.

${ }^{5}$ LCG 3,5= leite corrigido para teor de gordura igual a 3,5\%.

${ }^{6} \mathrm{NUL}=$ nitrogênio uréico no leite.

${ }^{7} \mathrm{NUP}=$ nitrogênio uréico no plasma.

Letras diferentes nas linhas referem-se a médias que diferem entre si pelo Teste dos Quadrados Mínimos $(P<0,05)$. 


\subsubsection{Ingestão de matéria seca}

A ingestão de MS não foi afetada $(P>0,05)$ pelo grau de moagem do milho. San Emeterio et al. (2000) e Dhiman et al. (2002) também não observaram diferenças na ingestão de MS quando compararam milho moído fino e milho moído grosso.

O aumento da degradabilidade ruminal do amido do milho ou sorgo, através da floculação, também não afetou a ingestão de MS na maioria dos trabalhos revisados por Theurer et al. (1999a), em comparação com o processo de laminação a seco ou a vapor.

Em alguns trabalhos, tem sido observado o efeito do processamento de grãos na ingestão de MS. Nussio et al. (2002) compararam diferentes formas de processamento de milho para vacas em final de lactação, também alimentadas com rações contendo silagem de milho como volumoso. Esses autores observaram resultados diferentes aos do presente estudo, com tendência de aumento da ingestão de MS para as vacas que receberam milho moído fino em comparação com moído grosso ou floculado. Por outro lado, Yu et al. (1998) observaram que vacas alimentadas com rações contendo milho moído fino apresentaram menor ingestão de MS, comparadas àquelas alimentadas com rações contendo milho moído grosso, quando o volumoso fornecido foi o feno de alfafa.

Pode ser que haja influência do teor de umidade da ração sobre a ingestão de MS, em função do grau de moagem do milho. Em rações com alto teor de MS, como as utilizadas por Yu et al. (1998), a moagem fina pode aumentar a quantidade de pó e limitar a ingestão dos animais. É provável que em rações com maior teor de umidade, como ocorre quando se utiliza silagem de milho como volumoso, esse problema seja eliminado. A maior ingestão de MS observada por Nussio et al. (2002), para milho moído fino, pode ser conseqüência de uma maior taxa de passagem pelo rúmen, em comparação com o milho moído grosso. De modo geral os dados de literatura acima citados 
mostram que não há consistência quanto ao efeito do grau de moagem na ingestão de MS.

O tipo de subproduto utilizado, polpa cítrica ou casca de soja, não afetou a ingestão de MS $(P<0,05)$. Dados na literatura comparando polpa cítrica e casca de soja para vacas leiteiras são escassos. De acordo com a composição bromatológica e alta palatabilidade destes ingredientes, não seria de se esperar grandes diferenças em ingestão de MS entre esses subprodutos.

\subsubsection{Produção de leite}

A produção de leite não foi afetada pelo grau de moagem do milho e nem pelo tipo de subproduto $(P>0,05)$, semelhantemente ao observado por San Emeterio et al. (2000) e Callison et al. (2001).

Soriano et al. (2000) e Reis et al. (2001) também não observaram diferença na produção de leite quando forneceram milho com diferentes granulometrias para vacas em lactação mantidas em pastagem. Nesses trabalhos, as quantidades de milho fornecidas foram altas e podem ter resultado em ingestão de amido em excesso.

A ausência de efeito positivo do processamento mais intenso, ou seja, moagem fina em comparação com a moagem grossa, difere dos dados de Wilkerson et al. (1997), Yu et al. (1998), Theurer et al. (1999a) e Dhiman et al. (2002).

Os resultados do presente estudo também diferem do trabalho de Yu et al. (1998), que observou produção de leite maior para vacas alimentadas com milho floculado (360 g/L), intermediária com milho moído fino e menor com milho moído grosso, laminado, ou floculado excessivamente (309 g/L). A maior produção de leite de vacas alimentadas com milho floculado com densidade média e moído fino está associada com maior disponibilidade de energia dos grãos, principalmente por causa da maior degradação ruminal do amido. Maior quantidade de amido degradável no rúmen aumenta o desempenho lactacional, 
provavelmente devido a maior produção de ácidos graxos voláteis e maior produção microbiana. A menor produção para vacas alimentadas com milho floculado excessivamente (309 g/L) foi, provavelmente, causada por excessiva degradação ruminal de amido, que pode ter resultado em $\mathrm{pH}$ ruminal muito baixo. Por apresentarem menor ingestão de MS, vacas que receberam a ração contendo milho moído fino tiveram maior eficiência de conversão de alimento em leite do que aquelas alimentadas com milho moído grosso ou floculado.

Dhiman et al. (2002) também observaram maior produção de leite, porém com teor de gordura mais baixo, em vacas alimentadas com milho moído fino ou milho floculado, quando comparadas às que receberam milho moído grosso.

Alguns trabalhos compararam a moagem com outros métodos de processamento e obtiveram melhores resultados com a moagem. A produção de leite foi $2,2 \mathrm{~kg} / \mathrm{d}$ maior em vacas alimentadas com milho moído do que em vacas que receberam milho laminado, conforme trabalho de Wilkerson et al. (1997). De acordo com o autor, a redução no tamanho de partícula e o subseqüente aumento na área superficial no milho moído, comparado ao milho laminado, aumentou a digestibilidade dos nutrientes no trato total.

No trabalho de Knowiton et al. (1998) a produção de leite também foi maior, quando foi fornecido milho moído, em comparação ao milho quebrado, em rações fornecidas para vacas em lactação que receberam silagem de milho e de alfafa como volumoso.

Os trabalhos de Joy et al. (1997) e Crocker et al. (1998), que compararam milho floculado versus laminado, não mostraram diferença em produção de leite, assim como o de Uchida et al. (2001), que compararam milho moído versus laminado e forneceram silagem de alfafa como volumoso.

Em geral, os dados comparando grau de moagem de milho têm apresentado efeitos variáveis na produção de leite, ao contrário do efeito positivo consistente da floculação do milho e sorgo, em comparação com moagem ou laminação, conforme os dados revisados por Theurer et al. (1999a). Dados positivos com fontes de amido de alta degradabilidade ruminal 
têm sido menos freqüentes quando se trata de animais mantidos em pastagens, em comparação a animais confinados.

Houve interação significativa $(P<0,05)$ entre grau de moagem e tipo de subproduto para a produção de LCG 3,5. As combinações casca de soja com milho moído fino e polpa cítrica com milho moído grosso levaram à maiores produções de LCG 3,5. Provavelmente, isto ocorreu devido a influência dos efeitos benéficos da casca de soja sobre o ambiente ruminal, na ração contendo amido de maior degradabilidade ruminal, ou seja, com milho moído fino, enquanto a polpa cítrica compensou a menor degradabilidade ruminal do milho moído grosso, fornecendo carboidratos não estruturais de rápida e extensa degradação.

Nussio et al. (2002) obtiveram maior produção de LCG 3,5 com rações contendo milho moído fino e polpa cítrica, em comparação àquelas contendo apenas milho moído grosso. A combinação de milho floculado com polpa cítrica, nesse estudo, resultou em produção de LCG 3,5 maior que aquela contendo milho moído grosso.

Nos dados revisados, os tratamentos com milho processado mais intensamente, apresentam, na maioria das vezes, resultados positivos. Em alguns casos, diferenças no desempenho animal foram observadas quando as variações nos tamanhos médios de partículas do milho moído grosso e fino foram de 1,24 mm. Em outras situações variações de até 3,6 mm não levaram à mudanças no desempenho.

De qualquer forma, na maioria destes trabalhos revisados, não há vantagem de tratamentos com milho moído grosso ou laminado, comparados com aqueles contendo milho moído fino (San Emeterio et al., 2000; Soriano et al., 2000; Reis et al., 2001; Santos et al., 2001b; Dhiman et al., 2002; Nussio et al., 2002).

Não foram encontrados dados de literatura que compararam polpa cítrica com casca de soja. A ausência de diferença em produção de leite entre polpa 
cítrica e casca de soja, no presente estudo, sugere que os valores energéticos desses subprodutos se equivalem.

Bernard \& Mcneill (1991), Coomer et al. (1993) e Assis et al. (2004b) não observaram diferença na produção de leite quando substituíram milho por casca de soja. Já no trabalho de Ipharraguerre et al. (2002a), a produção de leite tendeu a diminuir quando a casca de soja representava $40 \%$ da MS da ração de vacas leiteiras.

\subsubsection{Eficiência alimentar}

A eficiência alimentar (LCG 3,5 / IMS) foi maior para os tratamentos MFCS e MGPC, havendo efeito da interação grau de moagem versus tipo de subproduto $(P<0,05)$, conseqüência dos maiores teores de gordura do leite e produção de leite corrigido para gordura nos tratamentos MFCS e MGPC.

Yu et al. (1998) constataram que a moagem fina do milho aumentou a eficiência alimentar em comparação à moagem grosseira, diferentemente de Dhiman et al. (2002), que não observaram efeito do processamento do milho sobre a eficiência. No trabalho de Theurer et al. (1999b) a eficiência alimentar não foi afetada pelo método de processamento do milho.

Coomer et al. (1993) compararam vários teores de carboidratos não estruturais na ração pela substituição de glúten de milho e casca de soja por milho e trigo. A eficiência alimentar tendeu a aumentar conforme diminuiu o teor de casca de soja na ração.

Cunningham et al. (1993) substituíram parte do concentrado ou do volumoso por casca de soja em rações para vacas leiteiras e não observaram diferença na eficiência alimentar entre as rações. 


\subsubsection{Composição do leite}

O teor de gordura do leite não foi afetado pelos tratamentos $(P>0,05)$. A produção de gordura do leite foi maior nos tratamentos MFCS e MGPC $(P<0,05)$ em conseqüência dos efeitos das combinações dos ingredientes, como discutido para LCG 3,5.

San Emeterio et al. (2000), Soriano et al. (2000), Callison et al. (2001) e Reis et al. (2001), que avaliaram formas de processamento do milho, não observaram efeitos na gordura do leite.

Normalmente o fornecimento de grãos de cereais processados mais intensamente (floculação versus moagem fina versus moagem grossa ou laminação) tendem a reduzir o teor de gordura e aumentar o teor de proteína do leite (Theurer et al., 1999a). A alimentação com milho floculado diminuiu em 7\% o teor de gordura do leite, comparado ao milho moído fino, em trabalho de Dhiman et al. (2002).

O teor de gordura do leite no trabalho de Yu et al. (1998) foi menor para vacas alimentadas com rações contendo milho floculado de baixa densidade do que para vacas que receberam milho laminado, o que pode estar associado com maior taxa de hidrólise do amido e efeito negativo sobre o $\mathrm{pH}$ ruminal. $\mathrm{A}$ concentração ruminal de propionato aumentou e a proporção molar de acetato:propionato diminuiu quando a disponibilidade de amido aumentou. Maior concentração de propionato ruminal aumenta a gluconeogênese, que pode estimular maior secreção de insulina, inibir a liberação de ácidos graxos pelo tecido adiposo para a glândula mamária e diminuir o teor de gordura do leite. A queda no $\mathrm{pH}$ ruminal pode interferir na biohidrogenação ruminal e aumentar o fluxo de ácidos graxos de cadeia trans para o intestino. Estes ácidos têm efeito negativo sobre a síntese de gordura na glândula mamária (Gaynor et al., 1994).

A substituição parcial de fontes de amido por subprodutos ricos em FDN de alta digestibilidade, como a casca de soja, ou em pectina como a polpa 
cítrica, pode ter efeito positivo sobre o teor de gordura do leite (Ipharraguerre et al., 2002a; Santos et al., 2004b). Entretanto, Bernard \& Mcneill (1991), Coomer et al. (1993) e Assis et al. (2004b) também não observaram mudanças no teor e na produção de gordura do leite quando substituíram milho moído por casca de soja. Não foram encontrados trabalhos comparando casca de soja com polpa cítrica na literatura.

Não houve efeito dos tratamentos sobre o teor de proteína do leite $(P>0,05)$, semelhantemente ao observado por San Emeterio et al. (2000), Soriano et al. (2000), Reis et al. (2001) e Callison et al. (2001). Houve tendência de maior produção de proteína do leite nos tratamentos MFCS e MGPC $(P<0,06)$.

Os efeitos positivos do aumento da degradabilidade ruminal do amido através da floculação sobre o teor e produção de proteína do leite, relatados de forma consistente por Theurer et al. (1999a), concordam com os dados de Wilkerson et al. (1997), que observaram maior proteína do leite quando utilizado milho moído do que milho laminado.

Knowlton et al. (1996) observaram aumento no teor de proteína do leite e Ekinci \& Broderick (1997) notaram que a produção de proteína do leite aumentou devido a moagem fina do milho. Já no trabalho de Dhiman et al. (2002) tanto o teor quanto a produção de proteína do leite foram maiores para o milho moído fino em comparação ao milho moído grosso. Os efeitos positivos do aumento na degradabilidade do amido sobre o teor de proteína do leite devem-se, provavelmente, à síntese microbiana mais intensa, que acarreta aumento no fluxo de proteína metabolizável para o intestino e melhora no perfil de aminoácidos essenciais (Santos et al., 1998).

$\mathrm{O}$ teor de lactose não foi afetado pelos tratamentos $(P>0,05)$. Dhiman et al. (2002) compararam diversos métodos de processamento de milho e também não observaram efeitos no teor de lactose do leite.

O teor de sólidos totais do leite tendeu a ser maior nos tratamentos MFCS e MGPC $(P<0,06)$ e a produção de sólidos totais do leite teve influência 
da interação grau de moagem do milho versus tipo de subproduto $(P<0,05)$ e foi maior nos tratamentos MFCS e MGPC.

O teor de nitrogênio uréico no leite foi maior nos tratamentos com milho moído fino $(P<0,05)$, oposto ao observado no trabalho de San Emeterio et al. (2000). Caso tenha ocorrido fermentação ruminal excessiva do amido do milho moído fino, esta poderia levar à diferenças nas taxas de degradação de carboidrato e proteína com conseqüente aumento do teor de nitrogênio amoniacal no fluido ruminal. Isso explicaria o maior teor de nitrogênio uréico no leite nas rações com milho moído fino, porém, não houve efeito do grau de moagem do milho sobre o teor de nitrogênio uréico no plasma, que, normalmente, é correlacionado positivamente com o teor de nitrogênio uréico no leite.

Soriano et al. (2000), Reis et al. (2001) e Dhiman et al. (2002) não observaram mudanças no teor de nitrogênio uréico no leite quando compararam milho moído fino e milho moído grosso, assim como Uchida et al. (2001), que compararam milho moído e laminado em rações baseadas em silagem de alfafa.

\subsubsection{Nitrogênio uréico e glicose no plasma sangüíneo}

Os teores de nitrogênio uréico e glicose no plasma sangüíneo não foram afetados pelo grau de moagem do milho e nem pelo tipo de subproduto $(P>0,05)$. Crocker et al. (1998) também não observaram diferença no teor de glicose plasmática quando forneceram milho moído e floculado em diversas proporções. No entanto, o teor de nitrogênio uréico plasmático foi maior nos animais que consumiram a ração que continha apenas milho moído, sem milho floculado.

No trabalho de Nussio et al. (2002) o teor de nitrogênio uréico plasmático foi menor para os animais alimentados com milho moído grosso, em 
comparação com o milho floculado fornecido com polpa cítrica. Já o teor de glicose não foi afetado pelos tratamentos.

Dhiman et al. (2002) também não observaram efeito do processamento do milho sobre o teor de glicose plasmática.

Os teores de glicose plasmática estão dentro das variações consideradas normais de 35 a 55 mg/dL, de acordo com Blood \& Radostits (1989) e de 42,1 a $74,5 \mathrm{md} / \mathrm{dL}$, conforme Fraser (1989).

\subsection{Conclusões}

O desempenho de vacas leiteiras com produção média 24 kg/d de leite não foi afetado pelo aumento do grau de moagem do milho.

Os subprodutos agroindustriais avaliados, ou seja, polpa cítrica e casca de soja, levaram a produções de leite semelhantes.

A polpa cítrica apresentou-se como melhor alternativa de subproduto nas rações com milho moído grosso, enquanto a casca de soja combinou melhor com o milho moído fino. 


\section{CONCLUSÕES GERAIS}

Nas condições experimentais em que foi avaliada, a utilização de aditivo microbiológico não melhorou o desempenho de vacas no terço final de lactação.

A substituição do milho moído por polpa cítrica peletizada em 50\%, para vacas produzindo ao redor de $19 \mathrm{~kg} / \mathrm{d}$ de leite, não afetou o desempenho dos animais.

O teor ótimo de amido total, em rações contendo silagem de milho como volumoso, foi de $25 \%$ (proporção milho:polpa de 2:1) para vacas produzindo cerca de $30 \mathrm{~kg} / \mathrm{d}$.

O grau de moagem do milho (fino ou grosso) não afetou o desempenho de vacas em lactação.

Baseado nos dados obtidos, supõe-se que a polpa cítrica e a casca de soja apresentam potencial semelhante de geração de energia para a síntese de leite. 


\section{REFERÊNCIAS BIBLIOGRÁFICAS}

ADAMS, A.L.; HARRIS, B.; VAN HORN, H.H. et al. Effects of varying forage types on milk production responses to whole cottonseed, tallow and yeast. Journal of Dairy Science, v.78, p.573-581, 1995.

ANDERSON, S.J.; MERILL, J.K.; MCDONNELL, M.L. et al. Digestibility and utilization of mechanically processed soybean hulls by lambs and steers. Journal of Animal Science, v.66, p.2965-2976, 1988.

ANDRADE, G.A. Substituição do milho moído por polpa cítrica no desempenho de vacas em lactação. Lavras, 2002. 151p. Dissertação (Mestrado) Universidade Federal de Lavras.

ARAMBEL, M.J.; KENT, B.A. Effect of yeast culture on nutrient digestibility and milk yield response in early to midlactation dairy cows. Journal of Dairy Science, v.73, p.1560-1563, 1990.

AROSEMENA, A.; DEPETERS, E.J.; FADEL, J.G. Extent of variability in nutrient composition within selected byproduct feedstuffs. Animal Feed Science and Technology, v.54, p.103-120, 1995. 
ASSIS, A.J.; CAMPOS, J.M.S.; VALADARES FILHO, S. et al. Polpa cítrica em dietas de vacas em lactação. 1. Consumo de nutrientes, produção e composição do leite. Revista Brasileira de Zootecnia, v.33, n.1, p.242250, 2004a.

ASSIS, A.J.; CAMPOS, J.M.S.; OLIVEIRA, A.S. et al. Casca de soja em dietas de vacas leiteiras. I - Consumo, variação de peso, produção e composição do leite (compact disc). In: REUNIÃO ANUAL DA SOCIEDADE BRASILEIRA DE ZOOTECNIA, 41., Campo Grande, 2004. Anais. Campo Grande: Sociedade Brasileira de Zootecnia, 2004b.

BARGO, F.; MULLER, L.D.; KOLVER, E.S. et al. Production and digestion of supplemented dairy cows on pasture. Journal of Dairy Science, v.86, n.1, p.1-42, 2003.

BATAJOO, K.K.; SHAVER, R.D. In situ dry matter, crude protein, and starch degradabilities of selected grains and byproducts. Animal Feed Science and Technology, v.71, p.165-176, 1998.

BELIBASAKIS, N. G.; TSIRGOGIANNI, D. Effects of dried citrus pulp on milk yield, milk composition and blood components of dairy cows. Animal Feed Science and Technology, v.60, n.1, p.87-92,1996.

BELYEA, R.L.; STEEVENS, B.J.; RESTREPO, R.J. et al. Variation in composition of byproduct feeds. Journal of Dairy Science, v.72, p.23392345, 1989.

BERGMAN E. N. Energy contributions of volatile fatty acids from the gastrointestinal tract in various species. Physiological Reviews. v.70, n.2, p.567-589, 1990. 
BERNARD, J.K.; McNEILL, W.W. Effect of high fiber energy supplements on nutrient digestibility and milk production of lactating dairy cows. Journal of Dairy Science, v.74, n.3, p.991-995, 1991.

BLOOD, D.C.; RADOSTITIS, O.M. Clínica Veterinária. 7 ed. Rio de janeiro: Guanabara, 1989. 1263p.

BRUCKENTAL, I.; DORI, D.; KAIM, M. et al. Effects of source and level of protein on milk yield and reproduvtive performance of high-producing primiparous and multiparous dairy cows. Animal Production, v.48, p.319329, 1989.

CALLAWAY, E.S.; MARTIN, S.A. Effects of Saccharomyces cerevisiae culture on ruminal bacteria that utilize lactate and digest cellulose. Journal of Dairy Science, v.80, p.2035-2044, 1997.

CALLISON, S.L.; FIRKINS, J.L.; EASTRIDGE, M.L. et al. Site of nutrient digestion by dairy cows fed corn of different particle sizes or steam-rolled. Journal of Dairy Science, v.84, n.6, p.1458-1467, 2001.

CARRO, M.D.; LEBZIEN, P.; ROHR, K. Effects of yeast culture on rumen fermentation, digestibility and duodenal flow in dairy cows fed a silage based diet. Livestock Production Science, v.32, p.219-229, 1992.

CARVALHO, M.P. Citros. In: SIMPÓSIO SOBRE NUTRIÇÃO DE BOVINOS, 6., Piracicaba, 1995. Anais. Piracicaba: FEALQ, 1995. p.171-214.

CHEN, K.H.; HUBER, J.T.; THEURER, C.B. et al. Effect of steam-flaking of corn and sorghum grains on performance of lactating cows. Journal of Dairy Science, v.77, p.1038, 1994. 
CHEN, K.H.; THEURER, C.B.; SIMAS, J.M.C. et al. Effect of substituting steam-flaked sorghum for concentrate on lactation and digestion in dairy cows. Journal of Dairy Science, v.78, p.362, 1995a.

CHEN, K.H.; HUBER, J.T.; SIMAS, J.M.C. et al. Effect of enzyme treatment or steam flaking of sorghum grain on lactation and digestion in dairy cows. Journal of Dairy Science, v.78, p.1721, 1995b.

CHESSON, A.; MONRO, J. Legume pectic substances and their degradation in the ovine rumen. Journal of Science Food Agriculture, v.33, p.852, 1982.

COOMER, J.C.; AMOS, H.E.; WILLIAMS, C.C. et al. Response of early lactation cows to fat supplementation in diets with different nonstructural carbohydrate concentrations. Journal of Dairy Science, v.76, n.12, p.3747-3754, 1993.

CONRAD, H.R.; HIBBS, J.W. Nitrogen metabolism in dairy cows. ii. Soybean flakes versus oats as principal sources of digestible carbohydrates for nitrogen metabolism. Journal of Dairy Science, v.44, p.1903-1909, 1961.

CROCKER, L.M.; DEPETERS, E.J.; FADEL, J.G. et al. Influence of processed corn grain in diets of dairy cows on digestion of nutrients and milk composition. Journal of Dairy Science, v.81, n.9, p.2394-2407, 1998.

CUNNINGHAM, K.D.; CECAVA, M.J.; JOHNSON, T.R. Nutrient digestion, nitrogen, and amino acid flows in lactating cows fed soybean hulls in place of forage or concentrate. Journal of Dairy Science, v.76, n.11, p.35233535, 1993. 
DANN, H.M.; DRACKLEY, J.K.; McCOY, G.C. et al. Effects of yeast culture (Saccharomyces cerevisiae) on prepartum intake and postpartum intake and milk production of jersey cows. Journal of Dairy Science, v.83, p.123-127, 2000.

DEAVILLE, E.R.; MOSS, A.R.; GIVENS, D.I. The nutritive value and chemical composition of energy-rich byproducts for ruminants. Animal Feed Science and Technology, v.49, p.1226-1276, 1994.

DEPETERS, E.J.; FADEL, J.G.; AROSEMENA, A. Digestion kinetics of neutral detergent fiber and chemical composition within some selected byproducts feedstuffs. Animal Feed Science and Technology, v.67, p.127-140, 1997.

DHIMAN, T.R.; ZAMAN, M.S.; McQUEEN, I.S. et al. Influence of corn processing and frequency of feeding on cow performance. Journal of Dairy Science, v.85, p.217-226, 2002.

DRUDE, R.E.; ESCANO, J.R.; RUSOFF, L.L. Values of complete feeds containing combinations of corn silage, alfafa pellets, citrus pulp and cotton seed hulls for lactating cow. Journal of Dairy Science, v.54, p.773, 1971.

EKINCI, C.; BRODERICK, G.A. Effect of processing high moisture ear corn on ruminal fermentation and milk yield. Journal of Dairy Science, v.80, n.12, p.3298-3307, 1997.

FARIA, V.P. de; TOSI, H.; GODOY, C.R.M. Polpa de laranja fresca e seca como aditivos para a ensilagem do capim elefante napier. O Solo, v.64, p.41-47, 1972. 
FEGEROS, K.; ZERVAS, G.; STAMOULI, S. et al. Nutritive value of dried citrus pulp and its effect on milk yield and milk composition of lactating ewes. Journal of Dairy Science, v.78, p.1116-1121, 1995.

FIRKINS, J.L. Effects of feeding nonforage fiber sources on site of fiber digestion. Journal of Dairy Science, v.80, p.1426-1437, 1997.

FIRKINS, J.L.; EASTRIDGE, M.L. Replacement of forage or concentrate with combinations of soyhulls, sodium bicarbonate, or fat for lactating dairy cows. Journal of Dairy Science, v.75, p.2752-2760, 1992.

FRASER, C.M. Manual Merck de Veterinária. 6 ed. São Paulo: Roca, 1991. $2169 p$.

GAYNOR, P.J.; ERDMAN, R.A.; TETER, B.B. et al. Milk fat yield and composition during abomasal infusion of cis or trans octadecenoates in holstein cows. Journal of Dairy Science, v.77, p.157-165, 1994.

GIARDINI, W. Polpa cítrica: o que é. Revista Batavo, v.23, p.4, 1993.

GRANT, R.J. Interactions among forages and nonforage fiber sources. Journal of Dairy Science, v.80, p.1438-1446, 1997.

GRAY, G.M. Starch digestion and absorption in nonruminants. Journal of Nutrition, v.122, p.172-177, 1991.

HARMON, D.L. Dietary influences on carbohydrases and small intestinal starch hydrolysis capacity in ruminants. Journal of Nutrition, v.122, p.203-210, 1992. 
HARRIS, B.; WOBB, D.W. The effect of feeding a concentrate yeast culture to lactating dairy cows. Journal of Dairy Science, v.73, Suppl.1, p.266, 1990.

HENTGES, J.F.; MORE, J.E.; PALMER, A.Z. et al. Replacement value of dried citrus meal for corn meal in beef cattle diets. Gainesville: University of Florida/Agricultural Experiment Station, 1966. 22p. (Bulletin, 708).

HERRERA - SALDANA, R.E.; ALARCON, R.G.; TORABI, M. et al. Influence of synchronizing protein and starch degradation in the rumen on nutrient utilization and microbial protein synthesis. Journal of Dairy Science, v.73, p.142, 1990.

HIGGINBOTHAM, G.E.; COLLAR, C.A.; ASELTINE, M.S. et al. Effect of yeast culture and Aspergillus oryzae extract on milk yield in a commercial dairy herd. Journal of Dairy Science, v.77, n.1, p.343-348, 1994.

HOOVER. W.H.; STOKES, S.R. Balancing carbohydrate and protein for optimum rumen microbial yield. Journal of Dairy Science, v.74, p.3630, 1991.

HSU, J.T.; FAULKNER, D.B.; GARLEB, K.A. et al. Evaluation of corn fiber, cottonseed hulls, oat hulls, and soybean hulls as roughage sources for ruminants. Journal of Dairy Science, v.65, p.244-255, 1987.

HUBER, J.T.; HERRERA - SALDANA, R.E. Synchrony of protein and energy supply to enhance fermentation. In: ASPLUND, J.M. Principles of Protein Nutrition of Ruminants. Boca Raton: C.R.C. Press, 1994. p.113. 
HUNTINGTON, G.B. Starch utilization by ruminants: from basics to the bunk. Journal of Animal Science, v.75, p.852-867, 1997.

IPHARRAGUERRE, I.R.; CLARK, J.H. Soyhulls as an alternative feed for lactating dairy cows: a review. Journal of Dairy Science, v.86, p.10521073, 2003.

IPHARRAGUERRE, I.R.; IPHARRAGUERRE, M.M.; CLARK, J.H. Performance of lactating dairy cows fed varying amounts of soyhulls as a replacement for corn grain. Journal of Dairy Science, v.85, p.2905-2912, 2002a.

IPHARRAGUERRE, I.R.; SHABI, Z.; CLARK, J.H. et al. Ruminal fermentation and nutrient digestion by dairy cows fed varying amounts of soyhulls as a replacement for corn grain. Journal of Dairy Science, v.85, p.2890-2904, 2002b.

JOY, M.T.; DEPETERS, E.J.; FADEL, J.G. et al. Effects of corn processing on the site and extent of digestion in lactating dairy cows. Journal of Dairy Science, v.80, n.9, p.2087-2097, 1997.

KNOWLTON, K.F; ALLEN, M.S.; ERICKSON, P.S. Lasalocid and particle size of corn grain for dairy cows in early lactation. 1. Effect on performance, serum metabolites, and nutrient digestibility. Journal of Dairy Science, v.79, p.557-564, 1996.

KNOWLTON, K.F.; GLENN, B.P.; ERDMAN, R.A. Performance, ruminal fermentation, and site of starch digestion in early lactation cows fed corn grain harvested and processed differently. Journal of Dairy Science, v.81, p.1972-1984, 1998. 
KUNG, L.; KRECK, E.M.; TUNG, R.S. Effects of a live yeast culture and enzymes on in vitro ruminal fermentation and milk production of dairy cows. Journal of Dairy Science, v.80, p.2045-2051, 1997.

LEIVA, E.; HALL, M.B.; VAN HORN, H.H. Performance of dairy cattle fed citrus pulp or corn products as sources of neutral detergent-soluble carbohydrates. Journal of Dairy Science, v.83, p.2866-2875, 2000.

LOGGINS, P.E.; AMMERMAN, C.B.; ARRINGTON, L.R. et al. Pelleted rations high in citrus byproducts and corn for fattening lambs. Journal of Animal Science, v.27, p.745, 1964.

LYKOS, T.; VARGA, G.A. Varying degradation rates of total nonstructural carbohydrates: effects on nutrient uptake and utilization by the mammary gland in high producing Holstein cows. Journal of Dairy Science, v.80, p.3356-3367, 1997.

LYKOS, T.; VARGA, G.A.; CASPER, D. Varying degradation rates of total nonstructural carbohydrates: effects on ruminal fermentation, blood metabolites, and milk production and composition in high producing Holstein cows. Journal of Dairy Science, v.80, n.12, p.3341-3355, 1997.

LUCCI, C.S.; VELLOSO, L.; MASOTTI, N. et. al. Polpa seca de laranja versus milho desintegrado em misturas concentradas para vacas em lactação. Revista da Faculdade de Medicina Veterinária e Zootecnia da Universidade de São Paulo, v.12, p.163-168, 1975.

MARTIN, S.A.; NISBET, D.J. Effect of direct-fed microbial on rumen microbial fermentation. Journal of Dairy Science, v.75, p.1736-1744, 1992. 
MARTINEZ, J.C. Substituição do milho moído fino por polpa cítrica peletizada no concentrado de vacas leiteiras mantidas em pastagens de capim elefante durante o outono - inverno. Piracicaba, 2004. 110p. Dissertação (Mestrado) - Escola Superior de Agricultura "Luiz de Queiroz", Universidade de São Paulo.

McCULLOUGH, M.E. Some selections from recent mutings. Macs Comments on Dairy Cattle Nutrition, v.14, n.8, p.95, 1995.

MERTENS, D.R. Creating a system for meeting the fiber requirements of dairy cows. Journal of Dairy Science, v.80, p.1463-1481, 1997.

MIRON, J.; YOSEF, E.; BEN-GHEDALIA, D. Composition and in vitro digestibility of monosaccharide constituents of selected byproducts feed. Journal of Agriculture and Food Chemistry, v.49, p.2322-2326, 2001.

MOORE, J.A.; POORE, M.H.; ECK, T.P. et al. Sorghum grain processing and buffer addition for early lactation cows. Journal of Dairy Science, v.75, p.3465, 1992.

MOREIRA, P.C.; REIS, R.B.; LANA, A.M.Q. et al. Produção e composição do leite de vacas alimentadas com polpa cítrica em substituição ao milho grão (compact disc). In: REUNIÃO ANUAL DA SOCIEDADE BRASILEIRA DE ZOOTECNIA, 41., Campo Grande, 2004. Anais. Campo Grande: Sociedade Brasileira de Zootecnia, 2004.

NAKAMURA, T.; OWEN, F.G. High amounts of soyhulls for pelleted concentrate diets. Journal of Dairy Science, v.72, p.988-994, 1989. 
NATIONAL RESEARCH COUNCIL. Nutrient requirements of domestic animals. Nutrient requeriments of dairy cattle. 6 . ed. revisada Washington: National Academy of Science, 1989. 157p.

NATIONAL RESEARCH COUNCIL. Nutrient requirements of domestic animals. Nutrient requeriments of dairy cattle. 7 . ed. revisada Washington: National Academy of Science, 2001. 381p.

NEWBOLD, C.J.; WALLACE, R.J.; McINTOSH, F.M. Mode of action of the yeast Saccharomyces cerevisiae as a feed aditive for ruminants. British Journal of Nutrition, v.76, p.249-261, 1996.

NISBET, D.J.; MARTIN, S.A. Effect of a Saccharomyces cerevisiae culture on lactate utilization by the ruminal bacterium Selenomonas ruminantium. Journal of Animal Science, v.69, p.4628-4633, 1991.

NOCEK, J.E.; TAMMINGA, S. Site of digestion of starch in the gastrointestinal tract of dairy cows and its effect on milk yield and composition. Journal of Dairy Science, v.74, p.3598-3629, 1991.

NUSSIO, L.G. Cultura de milho para produção de silagem de alto valor alimentício. In: SIMPÓSIO SOBRE NUTRIÇÃO DE BOVINOS, 4., 1991. Anais. Piracicaba: FEALQ, 1991. p. 59-168.

NUSSIO, C.M.B.; SANTOS, F.A.P.; PIRES. A.V. et al. Fontes de amido de diferentes degradabilidades e sua substituição por polpa de citrus em dietas para vacas leiteiras. Acta Scientiarum, v.24, n.4, p.1079-1086, 2002. 
OBA, M.; ALLEN, M.S. Effect of brown mibrid 3 mutation in corn silage on productivity of dairy cows fed two levels of dietary NDF: 1 . Feeding behavior and nutrient utilization. Journal of Dairy Science, v.83, p.1333-1341, 2000.

OBA, M.; ALLEN, M.S. Effects of corn grain conservation method on feeding behavior and productivity of lactating dairy cows at two dietary starch concentrations. Journal of Dairy Science, v.86, p.174-183, 2003.

OLIVEIRA, J.S.; HUBER, J.T.; BEN - GHEDALIA, D. et al. Influence of sorghum grain processing on performance of lactating dairy cows. Journal of Dairy Science, v.76, p.575, 1993.

OLIVEIRA. J.S.; HUBER, J.T.; SIMAS, J.M.C. et al. Effect of sorghum grain processing on site and extent of digestion of starch in lactating dairy cows. Journal of Dairy Science, v.78, p.1318, 1995.

ORSKOV, E.R. The feeding of ruminants: principles and practice. Chalcombe: Rowett Research Institute, 1987. 113p.

OWENS, F.N.; ZINN, R.A.; KIM, Y.K. Limits to starch digestion in the ruminant small intestine. Journal of Animal Science, v.63, p.1634-1648, 1986.

PANTOJA, J.; FIRKINS, J.L.; EASTRIDGE, M.L. et al. Effects of fat saturation and source of fiber on site of nutrient digestion and milk production by lactating dairy cows. Journal of Dairy Science, v.77, p.2196-2206, 1994. 
PIVA, G.; BELLADONA, S.; FUSCONI, G. et al. Effects of yeast on dairy cow performance, ruminal fermentation, blood components, and milk manufacturing properties. Journal of Dairy Science, v.76, p.2717-2722, 1993.

PLASCENCIA, A.; ZINN, R.A. nfluence of flake density on the feeding value of steam processed corn in diets for lactating dairy cows. Journal of Animal Science, v.74, p.310-316, 1996.

POORE, M.H.; MOORE, J.A.; SWINGLE, R.S. et al. Effect of fiber source and ruminal starch degradability on site and extent of digestion in dairy cows. Journal of Dairy Science, v.76, p.2244, 1993a.

POORE, M.H.; MOORE, J.A.; SWINGLE, R.S. et al. Response of lactating Holstein cows to diets varying in fiber source and ruminal starch degradability. Journal of Dairy Science, v.76, p.2235, 1993b.

PUTMAN, D.E.; SCHWAB, C.G.; SOCHA, M.T. et al. Effect of yeast culture in the diets of early lactation dairy cows on ruminal fermentation and passage of nitrogen fractions and amino acids to the small intestine. Journal Dairy Science, v.80, p.374-384, 1997.

REINATO, J.D.; EZEQUIEL, J.M.B.; GALATI. R.L. et al. Efeitos da substituição do milho pela polpa cítrica sobre o $\mathrm{pH}$ e nitrogênio amoniacal em dietas contendo dois níveis de subproduto da produção de lisina (SPL) (compact disc). In: REUNIÃO ANUAL DA SOCIEDADE BRASILEIRA DE ZOOTECNIA, 39., Recife, 2002. Anais. Recife: Sociedade Brasileira de Zootecnia, 2002. 
REIS, R.B.; SAN EMETERIO, F.; COMBS, D.K. et al. Effects of corn particle size and source on performance of lactating cows fed direct-cut grasslegume forage. Journal of Dairy Science, v.84, p.429-441, 2001.

REYNOLDS, C.K.; HUNTINGTON, G.B.; TYRREL, H.F. et al. Net portal drained visceral and hepatic metabolism of glucose, L-lactate and nitrogenous compounds in lactating Holstein cows. Journal of Dairy Science, v.71, p.1803, 1988a.

REYNOLDS, C.K.; HUNTINGTON, G.B.; TYRREL, H.F. et al. Net metabolism of volatile fatty acids, $\mathrm{d}$ b hidroxibutirate, nonesterified fatty acids, and blood gases by portal drained viscera and liver of lactating Holstein cows. Journal of Dairy Science, v.71, p.2395, 1988b.

REYNOLDS, C.K.; HARMON, D.L.; CECAVA. M.J. Absorption and delivery of nutrients for milk protein synthesis by portal drained viscera. Journal of Dairy Science, v.77, p.2787, 1994.

ROBINSON, P.H. Effect of yeast culture (Saccharomyces cerevisiae) on adaptation of cows to diets postpartum. Journal of Dairy Science, v.80, p.1119-1125, 1997.

ROBINSON, P.H.; GARRET, J.E. Effect of yeast culture (Saccharomyces cerevisiae) on adaptation of cows to postpartum diets and on lactational performance. Journal of Animal Science, v. 77, p.988-999, 1999. 
ROCHA FILHO, R.R. Efeitos da polpa cítrica e do milho sobre parâmetros ruminais. Piracicaba, 1988. 71p. Dissertação (Mestrado) - Escola Superior de Agricultura "Luiz de Queiroz", Universidade de São Paulo.

ROJAS, A.B.; GAMBOA, L.; VILLAREAL, M. et al. La substituicion de maiz por pulpa de citricos deshidratada sobre la produccion y composicion láctea de vacas encastadas holstein en el tropico humero de Costa Rica. Agronomia Costarricense, v.25, n.1, p.45-52, 2001.

ROSENDO, O.; HALL, M.B.; STAPLES, C.R. et al. Effects of polysaccharides on fiber digestion kinetics and microbial protein production in vitro. Journal of Dairy Science, v.82, Suppl. 1, p.89, 1999.

SAN EMETERIO, F.; REIS, R.B.; CAMPOS, W.E. et al. Effect of coarse or fine grinding on utilization of dry or ensiled corn by lactating dairy cows. Journal of Dairy Science, v.83, p.2939-2848, 2000.

SANTOS, F.A.P.; HUBER, J.T.; THEURER, C.B. et al. Response of lactating dairy cows to various densities of sorghum grain. Journal of Animal Science, v.75, p.1681-1685, 1997.

SANTOS, F.A.P.; HUBER, J.T.; THEURER. C.B. Milk yield and composition of lactating cows fed steam-flaked sorghum and graded concentrations of ruminally degradable protein. Journal of Dairy Science, v.81, p.215-220, 1998. 
SANTOS J.E.P.; HUBER, J.T.; THEURER, C.B. et al. Performance and nutrient by dairy cows treated with bovine somatotropin and fed diets with steamflaked sorghum or steam-rolled corn during early lactation. Journal of Dairy Science, v.82, p.404-411, 1999a.

SANTOS, J.E.P.; HUBER, J.T.; THEURER, C.B. et al. Response of lactating dairy cows to steam-flaked sorghum, steam-flaked corn, or steam-rolled corn and protein sources of differing degradability. Journal of Dairy Science, v.82, n.4, p.728-737, 1999 b.

SANTOS, F.A.P.; JUCHEM, S.O.; IMAIZUMI, H. et al. Suplementação de fontes de proteína e de amido com diferentes degradabilidades ruminais para vacas em lactação. In: REUNIÃO ANUAL DA SOCIEDADE BRASILEIRA DE ZOOTECNIA, 38., Piracicaba, 2001. Anais. Piracicaba: FEALQ, 2001a. p. 1278-1280.

SANTOS, F.A.P.; MENEZES Junior, M.P.; SIMAS, J.M.C. et al. Processamento do grão de milho e sua substituição parcial por polpa de citros peletizada sobre o desempenho, digestibilidade de nutrientes e parâmetros sanguíneos. Acta Scientiarum, v.23, n.4, p.923-931, $2001 b$.

SANTOS, F.A.P.; PEREIRA, E.M.; PEDROSO, A.M. Suplementação energética de bovinos de corte em confinamento. In: SIMPÓSIO SOBRE BOVINOCUlTURA DE CORTE, 5., Piracicaba, 2004. Anais. Piracicaba: FEALQ, 2004a. p.262-297. 
SANTOS, F.A.P.; MARTINEZ, J.C.; CARMO, C.A. et al. Sistema de alimentação com mecanismos de flexibilidade para a produção de leite. In: ZOCCAL, R.; AROEIRA, L.J.M.; MARTINS, P.C.; MOREIRA, M.S.P.; ARCURI, P.B. (Ed.) Leite: uma cadeia produtiva em transformação. Juiz de Fora: Embrapa Gado de leite, 2004b. cap. 12, p.117-161.

SARWAR, M.; FIRKINS, J.L.; EASTRIDGE, M.L. Effects of varying forage or concentrate carbohydrates on nutrient digestibilities and milk production by dairy cows. Journal of Dairy Science, v.75, p.1533-1542, 1992.

SAS INSTITUTE. SAS: user's guide; statistics. Version 8e. Cary, 1999. 965p.

SCOTON, R.A. Substituição do milho moído fino por polpa cítrica peletizada e/ou raspa de mandioca na dieta de vacas leiteiras em final de lactação. Piracicaba, 2003. 55p. Dissertação (Mestrado) - Escola Superior de Agricultura "Luiz de Queiroz", Universidade de São Paulo.

SCHAIBLY, G.E.; WING, J.M. Effects of roughage concentrate ration on digestibility and rumen fermentation of corn silage citrus pulp rations. Journal of Animal Science, v.38, p.697-701, 1974.

SCHULTZ, T.A.; COLLAR, C.A.; BATH, D.L. et al. Rumen digestion of various dairy feedstuffs compared in tests. California Agriculture, v.47, p.29, 1991.

SHABI, Z.; BRUCKENTAL. I.; ZAMWELL. S. et al. Effects of extrusion of grain and feeding frequency on rumen fermentation, nutrient digestibility, and milk yield and composition in dairy cows. Journal of Dairy Science, v.82, n.6, p.1252-1260, 1999. 
SIMAS, J.M.C.; HUBER, J.T.; THEURER, C.B. et al. Influence of sorghum grain processing in dairy cows fed varying levels of fat on performance and nutrients digestibilities. Journal of Dairy Science, v.77, Suppl. 1, p. 234, 1994.

SIMAS, J.M.C.; HUBER, J.T.; WU, Z. et al. Influence of steam-flaked sorghum grain and supplemental fat on performance of dairy cows in early lactation. Journal of Dairy Science, v.78, p.1526, 1995.

SIMAS. J.M.C. Processamento de grãos para rações de vacas leiteiras. In: SIMPÓSIO SOBRE PRODUÇÃO ANIMAL, 9., Piracicaba, 1996. Anais. Piracicaba: FEALQ, 1996. p.7-32.

SNIFFEN, C.J. Balancing rations for carbohydrates for dairy cattle. In: FEED DEALER SEMINARS, Ithaca, 1988. Proceedings. Ithaca: Cornell Cooperative Extension, 1988. p.9-19.

SODER, K.J.; HOLDEN, L.A. Dry matter intake and milk yield and composition of cows fed yeast prepartum and postpartum. Journal of Dairy Science, v.82, p.605-610, 1999.

SOLOMON, R.; CHASE, L.E.; BEN - GHEDALIA, D. et al. The effect of nonstructural carbohydrate and addition of full fat extruded soybeans on the concentration of conjugated linoleic acid in the milk fat of dairy cows. Journal of Dairy Science, v.83, p.1322-1329, 2000.

SORIANO, F.D.; POLAN, C.E.; MILLER, C.N. Milk production and composition, rumen fermentation parameters, and grazing behavior of dairy cows supplemented with different forms and amounts of corn grain. Journal of Dairy Science, v.83, p.1520-1529, 2000. 
STERN, M.D.; ZIEMER, C.J. Consider value, cost when selecting nonforage fiber. Feedstuffs, n.1, p.14, 1993.

STROBEL, H.J.; RUSSEL, J.B. Effect of pH and energy spilling on bacterial protein synthesis by carbohydrate limited cultures of mixed rumen bacteria. Journal of Dairy Science, v.69, p.2941, 1986.

SUÑÉ, R.W.; MÜHLBACH, P.R.F. Efeito da adição da cultura de levedura (Saccharomyces cerevisiae) cepa 1026 na produção e qualidade do leite de vacas holandesas em pastejo. Revista Brasileira de Zootecnia, v.27, n.6, p.1248-1252, 1998.

SWARTZ, D.L.; MULLER, L.D.; ROGERS, G.W. et al. Effect of yeast cultures on performance of lactating dairy cows: a field study. Journal of Dairy Science, v.77, p.3073-3080, 1994.

THEURER, C.B. Grain processing effects on starch utilization by ruminants. Journal of Animal Science, v.63, p.1649-1662, 1986.

THEURER, C.B.; OLIVEIRA, J.S.; WU, Z. et al. Steam flaking with two dietary grain levels improves digestible starch intake and performance by lactating dairy cows. Journal of Dairy Science, v.74, Suppl. 1, p.246, 1991.

THEURER, C.B.; HUBER, J.T.; DELGADO, E. et al. Invited review: summary of steam-flaking corn or sorghum grain for lactaing dairy cows. Journal of Dairy Science, v.82, p.1950-1959, 1999a. 
THEURER, C.B.; LOZANO, O.; ALIO, A. et al. Steam-processed corn and sorghum grain flaked at different densities alter ruminal, small intestinal, and total tract digestibility of starch by steers. Journal of Animal Science, v.77, p.2824-2831, 1999b.

UCHIDA, K.; BALLARD, C.S.; MANDEBVU, P. et al. Effect of variation in proportion of corn meal and steam-rolled corn in diets for dairy cows on behavior, digestion and yield and composition of milk. Journal of Dairy Science, v.84, n.2, p.453-461, 2001.

VALADARES, R.F.D.; GONÇALVES, LC.; SAMPAIO, I.B. Níveis de proteína em dietas de bovinos. 2. Consumo, digestibilidade e balanço de compostos nitrogenados. Revista Brasileira de Zootecnia, v.6, p.1259-1263, 1997.

VALK, H.M.; POELHUIS, K.; WENTINK, H.J. Effects of fibrous and starchy carbohydrates in concentrates as supplements in a herbage-based diet for high yielding dairy cows. Netherlands Journal of Agricultural Science, v.38, p.475-486, 1990.

VAN SOEST, P.J. Soluble carbohydrates and the non-fiber components of feeds. Large Animal Veterinary, v.42, p.44, 1987.

VAN SOEST, P.J.; ROBERTSON, J.B.; LEWIS, B.A. Methods for dietary fiber, neutral detergent fiber, and nonstarch polysaccharides in relation to animal nutrition. Journal of Dairy Science, v.74, p.3583, 1991.

VAN SOEST, P.J. Nutrition ecology of the ruminants. Ithaca: Cornell University Press, 1994. 476p. 
VAN HORN, H.S.; MARSHALL, S.P.; WILCOX, C.J. et al. Complete rations for dairy cattle. III. Evaluation of protein percent and quality and citrus pulp corn substitutions. Journal of Dairy Science, v.58, n.8, p.1101-1108, 1975.

WAINMAN, F.W.; DEWEY, J.S. Feddingstuffs evaluation unit-fifth report. Chalcombe: Rowett Research Institute, 1988. 123p.

WALLACE, R.J. Rumen microbiology, biotechnology, and ruminant nutrition: progress and problems. Journal of Animal Science, v.72, p.2992-3003, 1994.

WILDMAN, E.E.; JONES, G.M.; WAGNER, P.E. et al. A dairy condition scoring system and its relationship to selected production characteristics. Journal of Dairy Science, v.65, p.495, 1982.

WILLIAMS, P.E.V.; TAIT, C.A.G.; INNES, G.M. et al. Effects of the inclusion of yeast culture (Saccharomyces cerevisiae plus growth medium) in the diet of dairy cows on milk yield and forage degradation and fermentation patterns in the rumen of steers. Journal of Animal Science, v.69, p.3016-3026, 1991.

WILKERSON, V.A.; GLENN, B.P.; MCLEOD, K.R. Energy and nitrogen balance in lactating dairy cows fed diets containing dry or high moisture corn in either rolled or ground form. Journal of Dairy Science, v.80, n.10, p.2487-2097, 1997.

WING, J.M. Citrus feedstuffs for dairy cattle. Gainesville: University of Florida/Agricultural Experiment Station, 1982. 25p. (Bulletin, 829) 
WOHLT, J.E.; FINKELSTEIN, A.D.; CHUNG, C.H. Yeast culture to improve intake, nutrient digestibility, and performance by dairy cattle during early lactation. Journal of Dairy Science, v.74, p.1395-1400, 1991.

WOHLT, J.E.; CORCIONE, T.T.; ZAJAC, P.K. Effects of yeast on feed intake and performance of cows fed diets based on corn silage during early lactation. Journal of Dairy Science, v.81, p.1345-1352, 1998.

YOON, I.K.; STERN, M.D. Influence of direct-fed microbials on ruminal microbial fermentation and performance of ruminants: a review. Australian Asian Journal of Animal Science, v.79, p.411-417, 1995.

YU, P.; HUBER, J.T.; THEURER, C.B. et al. Effect of feeding amaferm during hot weather on performance of dairy cows fed diets of steam -flaked or steam-rolled corn. Journal of Dairy Science, v.77, Suppl. 1, p.383, 1994.

YU, P.; HUBER, J.T.; THEURER, C.B. et al. Effect of corn processing on lactational performance of dairy cows. Journal of Dairy Science, v.78, p.210, 1995.

YU, P.; HUBER, J.T.; THEURER, C.B. et al. Effect of steam-flaked or steamrolled corn with or without Aspergillus oryzae in the diet on performance of dairy cows fed during hot weather. Journal of Dairy Science, v.80, n.12, p.3293-3297, 1997.

YU, P.; HUBER, J.T.; SANTOS, F.A.P. Effects of ground, steam-flaked, and steam-rolled corn grains on performance of lactating dairy cows. Journal of Dairy Science, v.81, n.3, p.777-783, 1998. 
ZINN, R.A.; ADAM, C.F.; TAMAYO, M.S. Interaction of feed intake level on comparative ruminal and total tract digestion of dry-rolled and steam-flaked corn. Journal of Animal Science, v.73, p.1239-1245, 1995. 